Feasibility of Conducting Wetfall Chemistry Investigations Around the Bowen Power Plant

\author{
N. C. J. Chen \\ A. A. N. Patrinos
}

OAK RIDGE NATIONAL LABORATORY OPERATED BY UNION CARBIDE CORPORATION - FOR THE DEPARTMENT OF ENERGY 


\section{DISCLAIMER}

This report was prepared as an account of work sponsored by an agency of the United States Government. Neither the United States Government nor any agency Thereof, nor any of their employees, makes any warranty, express or implied, or assumes any legal liability or responsibility for the accuracy, completeness, or usefulness of any information, apparatus, product, or process disclosed, or represents that its use would not infringe privately owned rights. Reference herein to any specific commercial product, process, or service by trade name, trademark, manufacturer, or otherwise does not necessarily constitute or imply its endorsement, recommendation, or favoring by the United States Government or any agency thereof. The views and opinions of authors expressed herein do not necessarily state or reflect those of the United States Government or any agency thereof. 


\section{DISCLAIMER}

Portions of this document may be illegible in electronic image products. Images are produced from the best available original document. 
Printed in the United States of America. Available from National Technical Information Service

U.S. Department of Commerce

5285 Port Royal Road, Springfield, Virginia 22161

NTIS price codes-Printed Copy: A05; Microfiche A01

This report was prepared as an account of work sponsored by an agency of the United States Government. Neither the United States nor any agency thereof, nor any of their employees, makes any warranty, expressed or implied, or assumes any legal liability or responsibility for any third party's use or the results of such use of any information, apparatus, product or process disclosed in this report, or represents that its use by such third party would not infringe privately owned rights. 
Contract No. W-7405-eng-26

Engineering Technology Division

\title{
FEASIBILITY OF CONDUCTING WETFALL CHEMISTRY INVESTIGATIONS AROUND THE BOWEN POWER PLANT
}
N. C. J. Chen
A. A. N. Patrinos

Date Published - October 1979

\author{
Prepared by \\ OAK RIDGE NATIONAL LABORATORY \\ Oak Ridge, Tennessee 37830 \\ operaled by \\ UNION CARBIDE CORPORATION \\ for the \\ DEPARTMENT OF ENERGY
}


THIS PAGE

WAS INTENTIONALLY

LEFT BLANK 
ACKNOWLEDGMENTS $\ldots \ldots \ldots \ldots \ldots \ldots \ldots \ldots \ldots \ldots \ldots \ldots \ldots \ldots \ldots \ldots \ldots \ldots$

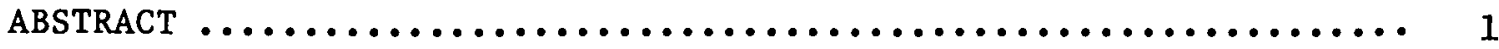

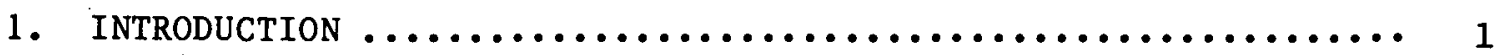

2. SURVEY OF WETFALL CHEMISTRY NETWORK $\ldots \ldots \ldots \ldots \ldots \ldots \ldots \ldots \ldots \ldots \ldots . \ldots$

2.1 Regional Studies $\ldots \ldots \ldots \ldots \ldots \ldots \ldots \ldots \ldots \ldots \ldots \ldots \ldots \ldots \ldots \ldots$

2.2 Local Studies ............................. 8

3. REVIEW OF SULFUR WASHOUT MODELS $\ldots \ldots \ldots \ldots \ldots \ldots \ldots \ldots \ldots \ldots \ldots \ldots \ldots$

3.1 Model by Scott and Hobbs $-1967 \ldots \ldots \ldots \ldots \ldots \ldots \ldots \ldots \ldots \ldots 12$

3.1 .1 Introduction .......................... 12

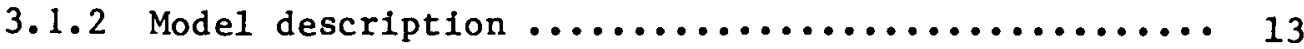

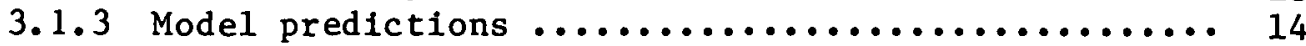

3.1 .4 Discussion of the model $\ldots \ldots \ldots \ldots \ldots \ldots \ldots \ldots \ldots \ldots \ldots$

3.2 Model by Hales, Wolf, and Dána $-1973 \ldots \ldots \ldots \ldots \ldots \ldots \ldots . \ldots 16$

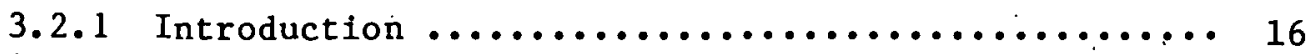

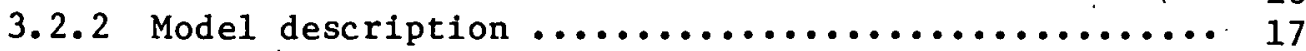

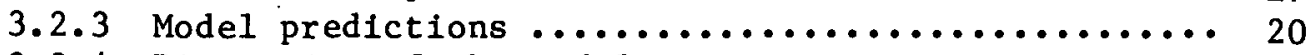

3.2 .4 Discussion of the model $\ldots \ldots \ldots \ldots \ldots \ldots \ldots \ldots \ldots \ldots . \ldots \ldots 22$

3. 3 Model by Dana, Drews, Glover, and Hales - $1976 \ldots \ldots \ldots \ldots 25$

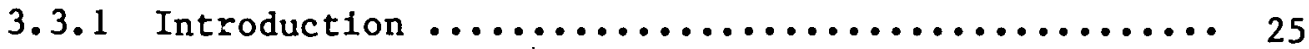

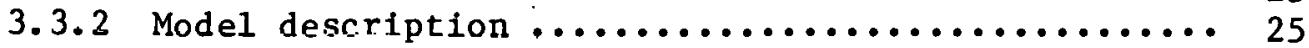

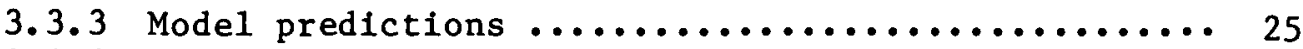

3.3 .4 Discussion of the model $\ldots \ldots \ldots \ldots \ldots \ldots \ldots \ldots \ldots . \ldots \ldots$

3.4 Model by Hill and Adamowicz $-1977 \ldots \ldots \ldots \ldots \ldots \ldots \ldots \ldots . . \ldots$

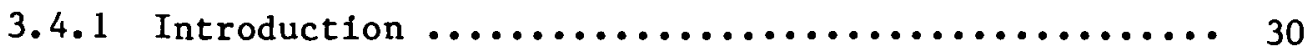

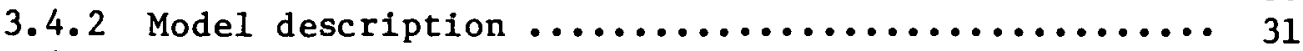

3.4 .3 Model pred1ct1ons $\ldots \ldots \ldots \ldots \ldots \ldots \ldots \ldots \ldots \ldots \ldots . \ldots \ldots$ 3?

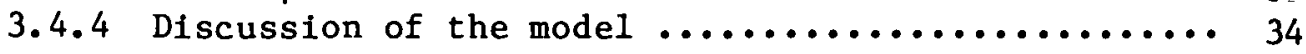

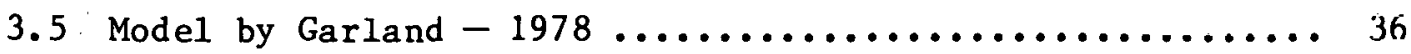

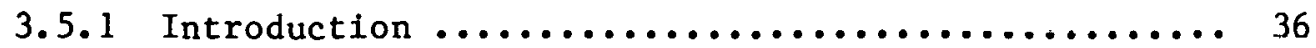

3.5 .2 Model description ...................... 36

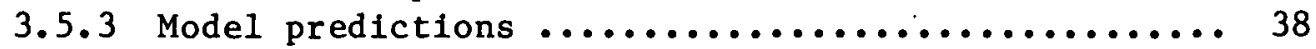

3.5 .4 Discussion of the model $\ldots \ldots \ldots \ldots \ldots \ldots \ldots \ldots \ldots \ldots . . . \ldots$

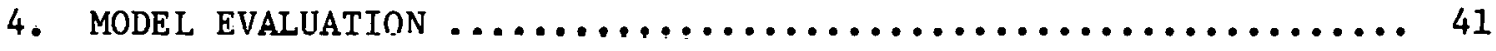

5. STUDIES OF WETFALL CHEMISTRY AROUND PLANT BOWEN .......... 46

5.1 Estimation of Sulfur Washout $\ldots \ldots \ldots \ldots \ldots \ldots \ldots \ldots \ldots \ldots . \ldots 4$

5.2 Estimation of Trace Metals Washout ............... 47

5.3 Spatial Variability in Precipitation ............... 52

5.4 Methodology $\ldots \ldots \ldots \ldots \ldots \ldots \ldots \ldots \ldots \ldots \ldots \ldots \ldots \ldots \ldots \ldots \ldots$ 
5.5 Site Criteria .............................. 54

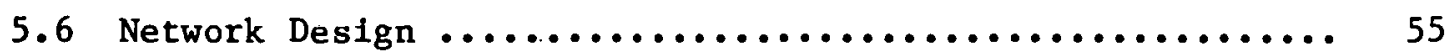

5.7 Data Acquisition, Analysis, and Discussion ........... 58

5.8 Data Analysis from HASL Automatic Samplers ............ 63

6. SUMMARY AND RECOMMENDATIONS $\ldots \ldots \ldots \ldots \ldots \ldots \ldots \ldots \ldots \ldots \ldots \ldots \ldots$

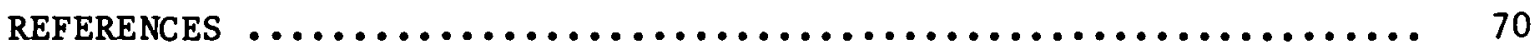


The preparation of this report was supported by the Department of Energy as part of the program on the Meteorological Effects of Thermal Energy Releases (METER). The authors are indebted to R. R. Turner of the Environmental Sciences Division and E. C. Hise of the Engineering Technology Division for reviewing the manuscript. In addition, the authors thank S. Lindberg and P. Lowry of Environmental Sciences Division for helpful discussions on the manuscript and for the laboratory measurements at the initial stage of the program, respectively. Others within METER also offered help for this report, including R. L. Miller, who obtained weather information for field trips, and R. E. Saylor, who collected weekly data from two automatic samplers. 


\title{
FEASIBILITY OF CONDUCTING WETFALL CHEMISTRY INVESTIGATIONS AROUND THE BOWEN POWER PLANT
}
N. C. J. Chen
A. A. N. Patrinos

\begin{abstract}
The feasibiliy of expanding the Meteorological Effects of Thermal Energy Releases-Oak Ridge National Laboratory (METERORNL) research at Bowen Power Plant in northwest Georgia to include wetfall chemistry is evaluated using (1) results of similar studies around other power plants, (2) several atmospheric washout models, (3) analysis of spatial variability in precipitation, and (4) field logistical considerations. An optimal wetfall chemistry network design is proposed, incorporating the inner portion of the existing rain-gauge network and augmented by additional sites to ensure adequate coverage of probable target areas.

The predicted sulfate production rate differs by about four orders of magnitude among the models reviewed with a $\mathrm{pH}$ of 3. No model can claim superiority over any other model without substantive data verification. The spatial uniformity in rain amount is evaluated using four storms that occurred at the METER-ORNL network. Values of spatial variability ranged from 8 to $31 \%$ and decreased as the mean rainfall increased. The field study of wetfall chemistry will require a minimum of 5 persons to operate the approximately 50 collectors covering an area of $740 \mathrm{~km}^{2}$. Preliminary wetfall-only samples collected on an event basis showed lower $\mathrm{pH}$ and higher electrical conductivity of precipitation collected about $5 \mathrm{~km}$ downwind of the power plant relative to samples collected upwind. Wetfall samples collected on a wcekly basis using Health and Safety Laboratories (HASL) automatic samplers, however, showed variable results, with no consistent pattern. This suggests the need for event sampling to minimize variable rain volume and multiplesource effects often associated with weekly samples.
\end{abstract}

\section{INTRODUCTION}

The Meteorological Effects of Thermal Energy Releases (METER) Program was organized by the Department of Energy (DOE), Division of Advanced Nuclear Systems and Projects and Division of Occupational Health and Environmental Research to determine the extent to which the heat and 
molsture releases from evaporative cooling towers and ponds of large power plants influence local and reglonal weather. Within the scope of atmospheric effects of concern to the METER Program, studies by the Oak Ridge National Laboratory (ORNL) currently focus on potential rainfall modifications from Bowen Electrical Generating Plant in northwest Georgla, which utilizes four natural-draft cooling towers. The study is composed of two parts: (1) a collection of 30-year climatological data as supplied by the National Weather Service is being evaluated for natural variability, and (2) a high-density recording rain-gauged network with 49 gauges in a 7 by 7 matrix that covers a square of 4.5 hy $45 \mathrm{~km}$ (28 by 28 miles) has been operating since February 1978. Both parts of the study are almed at obtaining quantitative estimates of potential plant-induced precipitation augmentation and storm pattern disruption.

This report considers the feasibility of expanding the METER-UKNL research to include rain chemistry by using (1) results of similar studles around other power plants, (2) several atmospheric washout models, (3) analysis of spatial variability in rain volume, and (4) field logistical considerations. The intent is to determine the extent to which the power plant plume affects rain chemistry locally.

Wet and dry deposition constitute the principal proresses of the removal of air pollurants. Wet dcposition, or wetfall, comprises the incurporation of aerosols and gases in cloud droplets (rainout) and removal by falling precipitation (washout); dry deposition, or dryfal1, denotes the direct collection of gaseous and particulate speries on a land or water surface by grovitational settling, impactiun, and adsorption during dry weather. Nuring the process of precipitation, substances are removed from large volumes of a gas and concentrated into a small volume of liquid - a key phenomenon in remnval of all matcrials,

Collection and analysis of rafnwater on an event basis and excluding dryfall will be emphasized in this study. This approach maximizes the ability to detect. plume-scavenging effects and defines the magnitude of contribution by precipitation to sulfur dioxide, hydrogen ion, and trace metals deposition. Samples are to be collected during frontal-type precipitation events, which offer the most favorable conditions for resolution of effects because they generally provide uniform rainfall with 
a long duration. Moreover, target and control areas for these rain episodes are relatively easy to identify with knowledge of surface and upperalr winds.

The collection of rainwater has been pursued systematically since early 1946 when the European Atmospheric Chemistry Network (EACN) ${ }^{1},^{2}$ was established. Data analyses from this network led to the conclusion that acid rain in Sweden is probably imported from air pollution in England. Thus, a local "soot problem" was transformed into a reglonal "acid rain problem" as a result of the increasing height of smokestacks and the installation of more efficient particle precipitators. Because of the acid rain concern, a simflar network (but much smaller in scale) was initiated in the United States at White Mountain, New Hampshire, by Liken's group ${ }^{3}$ in 1968. More recently, the study of acid rain phenomenon was intensified: regional-scale studies Included programs of Multistate Atmospheric Power Production Pollution Study (MAP3S) ${ }^{4}$ and National Atmospheric Deposition Program (NADP) (NC-141); ${ }^{5}$ local-scale studies around power plants consisted of programs at Bowen, Keystone, ${ }^{6}$ Centralia, 7 Chalk Point, 8 and a large smelter at Sudbury. ${ }^{9}$ Descripitons of their objectives, network size, and species of pollutants monitored are summarized in Chapter 2.

The washout of sulfur dioxide from the atmosphere was considered the primary reason for increased acidity of rain in some areas. Growing concern regarding the environmental impact of acid rain prompted model developers to parameterize this phenomenon in models as a means to predict the rainfal $\perp$ chemical cumposition and time srale for $\mathrm{SO}_{2}$ removal. To evaluate feasibility of full-scale wetfall chemistry and to guide network design, five published sulfur washout models are discussed in Chapter 3; in these discussions, particular emphasis is placed on the basic principles and difficulties encountered with each model.

Sulfur washout involves several interrelated processes - the dynamics of plume chemistry, thermodynamics, and precipitation chemistry. To estimate sulfur washout, the following should be considered simultaneously: source characteristics of emission, plume rise, and dispersion; mass transport between raindrops and $\mathrm{SO}_{2}$; and $\mathrm{SO}_{2}$ transformation that involves 1n-plume and liquid-phase oxidation in the presence of catalysts. 
Based on these considerations, each model is evaluated and the comparisons are presented in Chapter 4.

In Chapter 5, estimations of sulfur and trace metals (mercury, copper, and lead) washout assoclated with Plant Bowen are given; the resulting optimal METER-ORNL wetfall chemistry network is presented. Analyses of raindrop concentrations of $\mathrm{SO}_{2}$ and $\mathrm{pH}$ values underneath plumes are estimated, with two assumptions: (1) Gaussian plume dispersion with the modification of particulate fall velocity with respect to the gao plume and (2) an empirical washout factor. In addition, three expluratory field Irips for data acquisition around Plant Rowen, along with sume preliminary measurements of wetfall composition at the plant's metcorologlcal station [ 5 kul ( 3 miles) northeast of the plant] and the Taylorsville power substation [ $8 \mathrm{~km}$ ( 5 miles) southwest of the plant] by two automatic samplers, are discusser.

A great amount of knowledge in wetfall chemistry has been acquired through intensified efforts in recent years, both theoretically and experimentally, but clearly there is still much to learn. The METER-ORNL research program at Plant Bowen hopefully will inttiate furthcr interuy and provide more scientific facts regarding local effects of power plant plumes on wetfa1. chemistry. Finally, a summary of the findings and recommendations based un these findings are given in Chapter 6. 


\section{SURVEY OF WETFALL CHEMISTRY NETWORK}

In this chapter, existing wetfall chemistry networks on both regional and local scales are described for the feasibility of expanding the METERORNL research at Bowen Power Plant to include wetfall chemistry. Emphasis is placed on the description of various networks. For theoretical aspects of the studies (acid rain, sulfur washout, and trace metal washout), the reader is referred to Chapters 3,4 , and 5 . Some background information is provided here.

Sulfur dioxide is one of the principal pollutants from the combustion of fuel. The worldwide sulfur emission is estimated to exceed $19.5 \times$ $10^{10} \mathrm{~kg}$ year ${ }^{-1}$ (Ref. 10). The major portion of atmospheric $\mathrm{SO}_{2}$ is probably removed by rainout and washout.11 Rainout is the removal of $\mathrm{SO}_{2}$ within clouds, and washout is removal by precipitation below clouds.

Acid precipitation was defined as rain or snow with $\mathrm{pH}$ values of less than 5.6 (Ref. 12). The unpolluted rafnwater is not neutral but is slightly acidic, with a pH of about 5.6 or 5.7 . This is the minimum $\mathrm{pH}$ value expected for pure water in equilibrium with an ambient concentration of atmospheric carbon dioxide (320 ppm).

The observed $\mathrm{pH}$ of rain and snow falling on much of northern Europe and the northeastern United States has been lowered to between 3 and 5 (Ref. 13). These regions are the recipients of global winds, which transport the acidic fallout of pollution released from the upwind industrial areas of western Europe and the American midwest. Trends in fuel consumption, fuel preference, and pollution control technology, such as increasing the height of smokestacks and installing particle precipitators, apparently transformed local "soot problems" into a regional "actd rain problem."14

\subsection{Regional Studies}

On the regional scale $(>500 \mathrm{~km})$, three programs are identified and summarized in Table 1. They are compared in terms of major characteristics, such as objeclives, chemical speries determined, and network size. 
Table 1. Sumary of precipitation chemistry networks - reglonal studies

\begin{tabular}{|c|c|c|c|c|}
\hline Program & Object Ives & $\begin{array}{c}\text { Chemical species } \\
\text { sampled }\end{array}$ & Remarks & Sources \\
\hline EACN & $\begin{array}{l}\text { To study the transport of constituents through the atmosphere } \\
\text { from geochemical aspects : source characteristics, amount, } \\
\text { c1rculation, and transfoma:1on processes } \\
\text { To determine the ecological Importance of tarious elenents } \\
\text { deposited from the atmospiere on the eartt's surface: } \\
\text { To study lorg-term trend aad spatial varlability in wat depo- } \\
\text { sition }\end{array}$ & $\begin{array}{l}\mathrm{PH}, \text { conductivity, } \mathrm{SO}_{4}{ }^{2-} \\
\mathrm{NH}_{4}^{+}, \mathrm{DO}_{3}^{-}, \mathrm{Cl}^{-}, \mathrm{Na}^{+} \\
\mathrm{K}^{+}, \mathrm{Mg}^{2+}, \mathrm{Ca}^{2+}\end{array}$ & $\begin{array}{l}\text { Network s1ze: }>3000 \mathrm{~km} \text {; } \\
\text { maximum number of s1tes: } \\
120 ; \text { operational period: } \\
1946 \text { to present }\end{array}$ & 1,2 \\
\hline MAP3S & $\begin{array}{l}\text { To characterize physical and chemical properties, transforma- } \\
\text { tion, and removal of atmospheric energy-related pollutants } \\
\text { To determine processes and parameters governing the vertical } \\
\text { and horizonial transport af pollutants } \\
\text { To develop and verify numerical models }\end{array}$ & $\begin{array}{l}\text { Same as } \mathrm{EACN} \text {, with ad- } \\
\text { ditional measurements } \\
\text { of } \mathrm{SO}_{2}, \mathrm{NO}_{3}{ }^{-} \text {, and } \mathrm{PO}_{4}{ }^{3-}\end{array}$ & $\begin{array}{l}\text { Network dimension: } 1500 \\
\times 1700 \mathrm{~km} \text {; number of } \\
\text { s1tes: } 12 \text {; operational } \\
\text { period: } 1976 \text { to present }\end{array}$ & 3,4 \\
\hline$N C,-141$ & $\begin{array}{l}\text { To determine sensitivity of solls and vegetation to deposi- } \\
\text { tion of acicic and other suhstances in precipltation } \\
\text { To characterize the physiological and ecological ef fec:s of } \\
\text { atmospherfc deposition on grcwth and repzoduction of } \equiv 1 \mathrm{sh} \text {, } \\
\text { wildife, trees, etc. } \\
\text { To determine the prevalent fatterns of meteo:ological cis- } \\
\text { persal and deposition of sibstances from the atmospheve } \\
\text { To determine the nature and rates of chemfcai changes in } \\
\text { nftrogen, sulfur, and other compounds during transport from } \\
\text { sources to receptors }\end{array}$ & Same as EACN & $\begin{array}{l}\text { Network size: eastern } \\
\text { two-thlids of United } \\
\text { States; number of sites: } \\
40 ; \text { operational period: } \\
1978 \text { to present }\end{array}$ & 5,6 \\
\hline
\end{tabular}

Sources:

1. I. Granat, "On the Var1ab1lity of Rafnwater Composition and E=rors in Est1mates of Areal Wet Defosit1on," p. 531 1n Precipitation Scavenging, ERDA Sympos1um Series 41, Report CONT-7\$1003 (1974).

2. L. Granat, "Sulfate in Precipltaticn as Observed by the European Atmospheric Chen1stry Network," Atmos. Environ. 12, 413-424 (1978).

3. M. C. MacCracken, "MAP3S: An Investigation of Atmospheric Energy-Relared Pollutants 1n the Northeastern United States," Atmos. Environ. 12, 649-659 (1978).

4. Battelle Pacific Northwest Laborator1es, The MAP3S Frecipitation Chemistry Network: First Feriozic Summary Report (September 1976-June 1977), Report PNL-2402 (0:tober 1977).

5. J. N. Galloway and E. B. Cowling, "The Effects of Precipitation on Aquatic and Terrestrial Ecosystems: A Proposed Precipitation Chem1stry Network," J. Air Pollut. Cortrol As8oc. 28, 229-235 :1978).

6. R. Semonin and H. Volchok, "Site Seiection and Ceztification," Site Committee on National Atmospleric Deposition Program, NC-141 (1978). 
Although their objectives differ somewhat, the programs all involve establishment of a large dense network for the creation of a sufficient data base.

The $\operatorname{EACN}^{1}, 2$ program is the only network that has operated since early 1946. Although the number of stations varied from year to year, the data were consistent and of good quality. Data analyses from this network led to the conclusion that acid rain in Sweden is probably attributable to air pollution in England.

The program MAP3S, 4 funded by DOE, was initiated in 1977. This program involves many research centers, including Brookhaven National Laboratory, Argonne National Laboratory, Battelle Pacific Northwest Laboratory, Health and Safety Laboratories, and the Illinois State Water Survey.

Finally, the recently initiated program NC-141 (Ref. 5) is a joint effort of a number of organizations. These include the U.S. Department of Agriculture, the Department of Energy, North Carolina State University, the University of Minnesota, Colorado State University, Illinois State Water Survey, the University of Florida, Purdue University, and Virginia Polytechnic Institute and State University. By following the EACN approach, samples of precipitation and dry particulate matter will be collected and shipped to a central laboratory for analysis to minimize changes in or contamination of the samples during transport prior to analysis.

In contrast to the regional scale, the Hubbard Brook Experimental Forest $(\mathrm{HBEF})^{3}$ program is a much smaller scale study (not really a network) but provides the longcot known rernrd (1964-1974) for pH of precipitation in the United States. This remote forest in the White Mountain of the northcentral portion of New Hampshire is maintained by the U.S. Forest Service for long-term, in-depth studies of hydrology, biogeochemistry, and ecology. Because of the prevailing westerly winds that have passed over major industrial centers in the eastern and midwestern United States, HBEF offers a prime site for monitoring changes in precipitation chemistry. In addition to $\mathrm{pH}$, the species monitored include: $\mathrm{SO}_{4}{ }^{2-}, \mathrm{NO}_{3}^{-}, \mathrm{Cl}^{-}, \mathrm{K}^{+}, \mathrm{Na}^{+}$, $\mathrm{Ca}^{2+}, \mathrm{Mg}^{2+}, \mathrm{Mn}^{2+}, \mathrm{Al}^{3+}, \mathrm{Fe}^{3+}$, and $\mathrm{PO}_{4}^{3-}$.

While the programs of EACN, MAP3S, and NADP placed their emphasis on wetfall depusition, the programs of Sulfate Regional Experiment (SURE) 15 
and Midwest Interstate Sulfur Transformation and Transport (MISTT) ${ }^{16}$ concentrated on dry deposition. Because wet and dry deposition are two major atmospheric inputs to terrestrial and aquatic ecosystems, the SURE and MISTT programs are mentioned.

The SURE program, funded by Electric Power Research Institute (EPRI), has operated since 1976 and is expected to be continued through 1980 . The main concern is placed on air quality by the use of ground and aircraft measurements. The SURE program has a threefold purpose: (1) to acquire air samples using aircraft, (2) to develop a special emissions inventory of $\mathrm{SO}_{x}$ from selected major urban centers and regional cunplexes, and (3) to develop and evaluate air quality by mathematical models. There are 54 ground stations distributed in the northeastern quadrant of the United States (scale $>1000 \mathrm{~km}$ ).

In contrast to SURF, which atudies alr quality in regions without plumes, the program MISTT, funded by the Environmental Protection Agency (EPA), places its priority on the studies of plumes rather than of dry deposition. Major objectives include (1) studies of in-plume sulfur transformation mechanisms, (2) aircraft samples, and (3) mathemation. model development.

\subsection{Local studies}

On the small-scale studies, six projects involving field measurements around power plants are identified and summarized in Table 2. These projects are compared for source rharacteriotirs, nelwork oise, number of sites, and range of measured concentration underncath plumes and for sulfur dioxide and $\mathrm{pH}$ in rainwater under the plumes. In most cases, depending on weather conditions, a variability of more. than twn srdere of magnilude was observed in precipitation $\mathrm{SO}_{2}$ and hydrogen ion concentration.

Metal smelters in Sudbury, Ontario,9 emit about 1.8 million metric tons of sulfur per year. 'l'his represents about $1 \%$ of the total annual anthropogenic global emissions of sulfur. These emissions may be widely distributed because they are discharged from a height of $381 \mathrm{~m}$, the tallest stack in the world. Studies by the Atmospheric Environment Service 
Table 2. Summary of wetfall networks - local studies

\begin{tabular}{|c|c|c|c|c|c|}
\hline \multirow{2}{*}{ Characteristics } & \multicolumn{5}{|c|}{ Power plant } \\
\hline & Sudbury & Bowen & Keystone & Centralia & Chalk Point \\
\hline Generating capacity, MW & & 3300 & 1800 & 700 & 710 \\
\hline $\mathrm{SO}_{2}$ emission rate; $\mathrm{Mg}$ day $^{-1}$ & 4000 & 500 & 260 & 140 & 240 \\
\hline Smokestack height, m & 381 & 300 & 240 & 143 & 133 \\
\hline $\begin{array}{l}\text { Network size: radial distance from } \\
\text { the source, } \mathrm{km}\end{array}$ & $20-70$ & $3-25$ & $2-6.4$ & $0.4-11$ & $0.5-5$ \\
\hline Number of sites & 56 & 50 & 194 & 90 & 13 \\
\hline Investigator and year & $\operatorname{AES}^{a}$ & $\begin{array}{l}\text { ORNL }^{b} \\
1978-1981\end{array}$ & $\begin{array}{l}\mathrm{PNL}^{c} \\
1969-1970\end{array}$ & $\begin{array}{l}\text { PNL } \\
1974\end{array}$ & $\begin{array}{l}\mathrm{UM}^{d} \\
1973\end{array}$ \\
\hline $\begin{array}{l}\text { Range of measured }\left[\mathrm{SO}_{2}\right] \text {, } \text { umoles }^{-1} \\
\text { liter }\end{array}$ & $\mathrm{NA}^{f}$ & $0.7-12^{e}$ & $0.1-29.1$ & $3.3-33$ & $\mathrm{NA}^{f}$ \\
\hline Range of measured $\mathrm{pH}$ & $3.52-4.84$ & $4.2-4.72$ & $3.5-5.6$ & $4.15-5.1$ & $3.0-5.7$ \\
\hline
\end{tabular}

a Atmospheric Environment Service, Downsview, Canada.

Oak Ridge National Laboratory.

Battelle Pacific Northwest Laboratories.

University of Maryland.

Estimated values from Chapter 5 of this report.

Not avallable. 
at Downsview, Canada, involve the sampling of precipitation on an event basis to detect sulfur and trace metal deposition within an area having a radius $\sim 50 \mathrm{~km}$ from the source. Estimates indicate that less than $1 \%$ of the sulfur emitted during a precipitation event is deposited in this area, whereas the fraction for trace metals is at least an order of magnitude higher than for sulfur.

ORNL is undertaking a preliminary study on wetfall chemistry around the Bowen Electric Generating Plant, a coal-fired 3200-MW(e) power plant near Cartersville, Georgia, about $64 \mathrm{~km}$ ( $40 \mathrm{miles}$ ) nurthwest of Atlanta. Plant Bowen is the site of an ongoing ORNL study on the potential precipitation modification effects of the plant's four natural-draft coniling cowers. This study involves the METER-ORNL network, 17 which is an array of 7 by 7 recording rain gauges and four windsets centered at plant Rowen and covering an area of $\sim 2050 \mathrm{~km}^{2}$ (800 sq miles). The wetfall chemistry study will utilize the sites of the inner 5 by 5 core of the METER-ORNL network plus numerous temporary sites. The predicted ranges of $\mathrm{SO}_{2}$ concentration and $\mathrm{pH}$ of rainwater underneath the plumes, as derived by the analysis in Chapter 4, are contained in tahılar matcrial in Cliapter 4.

The Keystone project, one of the earlier sulfur washout experiments, was conducted by Hales et 21.6 of Battelle Pacif1c Northwest Laboratories. The primary objective was to assess the effectiveness of precipitation washout as a mechanism for removing sulfur compounds from the plume of the Keystone plant; the secondary objective was to evaluate the relative importance of various interaction and atmospheric variables. The field Invesligation extended over three one-month periods in Keystone, where 11 to 23 tons of sulfur dioxide (depending on power output) were released hourly from two 243-m (800- $f t)$ stacks. During rain episodes in October and November 1969 and April and May 1970 and during snowfall in February 1970, a total of 22 experimental runs were made. Precipitation samplers were placed at intervals of 4 to $12^{\circ}$ on sampling lines encircling the Keystone station at radial distances of 2,4 , and $6.4 \mathrm{~km}(1-1 / 4,2-1 / 2$, and 4 miles). Chemical analyses were performed in a mobile field laboratory.

The Centralia project ${ }^{7}$ (the plant is located in southwestern Washington State) was another field experiment conducted by the Battelle Pacific 
Northwest Laboratories. From data analyses, the conclusion was reached that (1) sulfate concentrations, in rainwater underneath plumes appear insignificant at downwind distances less than about $10 \mathrm{~km}$; (2) ammonium, nitrate, and soluble phosphate ion concentrations were at or near normal background levels; and (3) the only species measured that showed plumerelated deposition patterns at all distances where samples were collected $(0.4$ to $11 \mathrm{~km})$ were $\mathrm{SO}_{2}$ and $\mathrm{H}^{+}$.

The Chalk Point ${ }^{8}$ study is the smallest (in scale) described. It was conducted by the University of Maryland and involved a network that encircled the power station from 0.5 to $5 \mathrm{~km}$. Rainwater $\mathrm{pH}$ was found to vary between 3.0 and 5.7. Wind dependence of acidic washout from the plume was also noted, but the degree of correlation was not clear.

Another local-scale study to note is the one currently under way at the Walker Branch Watershed in Tennessee. 18 The primary objective of this study is to quantify the atmospheric input of trace elements. The network, subjected to three power plant influences (Bu11 Run Power Plant, Kingston Power Plant, and Y-12 Plant), consists of six rain-activated wetfall collectors. Wetfall has been collected through a combination of event and continuous sampling at four throughfall, one ground-level incident, and one above-canopy incident precipitation sites. Samples have been analyzed for $\mathrm{pH}$, conductivity, sulfate, and trace metals (such as $\mathrm{Cd}, \mathrm{Mn}, \mathrm{Pb}$, and $\mathrm{Zn}$ ). 


\section{REVIEW OF SULFUR WASHOUT MODELS}

The washout of sulfur dioxide from the atmosphere (in the presence or absence of smokestack plumes) is a phenomenon that contributes to the production of acid rain. ${ }^{19}$ Effective models of the washout process are useful in predicting the rainwater chemical composition and the time scale for $\mathrm{SO}_{2}$ removal.

To answer the question of whether plume dynamics and model wasliuut priciples suggest a possibility of detecting an effect of the plume on wetfall chemistry at any point in time and opace, aud, also to determine the state of the art on sulfur washout, five publiohed models were reviewed. The coverage of each model includes an introduction, model description and predictions, and a general discussion of the model.

Twu principal types of washour models have been devised: physical and chemical. The following definftions are given by Hill and Adamowicz. 19 The physical models are mass transfer models in which the soluble gas is nominally regarded as inert but has a distribution coefficient that varies with $\mathrm{SO}_{2}$ uptake, thus taking into account in an approutimate way the variation in hydrogen ion concentration which occurs as $\mathrm{SO}_{2}$ dissolves in the falling raindrops. In the rhemical models, mass cranster is taken to he infinitcly rapil. Consequently, the composition of the falling rain is always in equilibrium with the concentration of $\mathrm{SO}_{2}$ in the atmosphere, subject to the electroneutrality condition and to the extent of production of sulfate ion by oxidation of hisulfite and aulfile lun.

\subsection{Model by Scott and Hobbs -1967}

\section{1 .1 Introduction}

The Scott and Hobbs model $1^{20}$ was specifically developed for predicting rainwater sulfate concentration in the absence of plumes. This model is included in this review because many nther modcls (described later) widely adopted its simulation of the chemical processes involving multiple reactive gases in raindrops during plume scavenging. This is a chemical model and describes the chemical equilibria for the $\mathrm{SO}_{2}-\mathrm{NH}_{3}-$ liquid $\mathrm{H}_{2} \mathrm{O}$ system, including carbon dioxide equilibria. The model 
introduced a first-order rate oxidation mechanism for $\mathrm{SO}_{4}$ production, with emphasis on the catalytic action of ammonia. Predicted results of sulfate concentration compare favorably with those of laboratory experiments.

\subsubsection{Model description}

As noted in the introduction, this is a chemical model and therefore does not include plume dynamics. Scott and Hobbs considered the chemical equilibrium for the $\mathrm{SO}_{2}-\mathrm{NH}_{3}-1$ iquid $\mathrm{H}_{2} \mathrm{O}$ system in the presence of carbon dioxide. These equilibria are:

$$
\begin{aligned}
& \mathrm{SO}_{2}(\mathrm{~g})+\mathrm{H}_{2} \mathrm{O} \leftrightharpoons \mathrm{SO}_{2} \cdot \mathrm{H}_{2} \mathrm{O}, \\
& \mathrm{SO}_{2} \cdot \mathrm{H}_{2} \mathrm{O} \leftrightharpoons \mathrm{H}^{+}+\mathrm{HSO}_{3}^{-}, \\
& \mathrm{HSO}_{3}^{-} \leftrightharpoons \mathrm{H}^{+}+\mathrm{SO}_{3} 2^{-}, \\
& \mathrm{NH}_{3}(\mathrm{~g})+\mathrm{H}_{2} \mathrm{O} \leftrightharpoons \mathrm{NH}_{3} \cdot \mathrm{H}_{2} \mathrm{O}, \\
& \mathrm{NH}_{3} \cdot \mathrm{H}_{2} \mathrm{O} \leftrightharpoons \mathrm{NH}_{4}^{+}+\mathrm{OH}^{-}, \\
& \mathrm{CU}_{2}(\mathrm{~g})+\mathrm{H}_{2} \mathrm{O} \leftrightharpoons \mathrm{CO}_{2} \cdot \mathrm{II}_{2} \mathrm{O}, \\
& \mathrm{CO}_{2} \cdot \mathrm{H}_{2} \mathrm{O} \leftrightharpoons \mathrm{H}^{+}+\mathrm{HCO}_{3}^{-}, \\
& \mathrm{HCO}_{3}^{-} \leftrightharpoons \mathrm{H}^{+}+\mathrm{CO}_{3}{ }^{-}, \\
& \mathrm{H}_{2} \mathrm{O} \leftrightharpoons \mathrm{H}^{+}+\mathrm{OH}^{-} .
\end{aligned}
$$

The corresponding equilibrium constants are defined:

$$
\begin{aligned}
& \mathrm{K}_{\mathrm{hs}}=\left[\mathrm{SO}_{2} \cdot \mathrm{H}_{2} \mathrm{O}\right] / \mathrm{P}_{\mathrm{SO}_{2}}, \\
& \mathrm{~K}_{1 \mathrm{~S}}=\left[\mathrm{Il}^{+}\right]\left[\mathrm{HSO}_{3}{ }^{-}\right] /\left[\mathrm{SO}_{2} \cdot \mathrm{H}_{2} \mathrm{O}\right] ; \\
& \mathrm{K}_{2 \mathrm{~S}}=\left[\mathrm{H}^{+}\right]\left[\mathrm{SO}_{3}{ }^{-}\right] /\left[\mathrm{HSO}_{3}{ }^{-}\right], \\
& \mathrm{K}_{\mathrm{ha}}=\left[\mathrm{NH}_{3} \cdot \mathrm{H}_{2} \mathrm{O}\right] / \mathrm{P}_{\mathrm{NH}_{3},}
\end{aligned}
$$




$$
\begin{aligned}
& \mathrm{K}_{\mathrm{la}}=\left[\mathrm{NH}_{4}^{+}\right]\left[\mathrm{OH}^{-}\right] /\left[\mathrm{NH}_{3} \cdot \mathrm{H}_{2} \mathrm{O}\right], \\
& \mathrm{K}_{\mathrm{hc}}=\left[\mathrm{CO}_{2} \cdot \mathrm{H}_{2} \mathrm{O}\right] / \mathrm{P}_{\mathrm{CO}_{2}}, \\
& \mathrm{~K}_{\mathrm{lc}}=\left[\mathrm{H}^{+}\right]\left[\mathrm{HCO}_{3}^{-}\right] /\left[\mathrm{CO}_{2} \cdot \mathrm{H}_{2} \mathrm{O}\right], \\
& \mathrm{K}_{2 \mathrm{c}}=\left[\mathrm{H}^{+}\right]\left[\mathrm{CO}_{3}{ }^{-}\right] /\left[\mathrm{HCO}_{3}^{-}\right], \\
& \mathrm{K}_{\mathrm{w}}=\left[\mathrm{H}^{+}\right]\left[\mathrm{OH}^{-}\right] .
\end{aligned}
$$

This system requires an electroneutrality state, as given by

$$
\left[\mathrm{H}^{+}\right]+\left[\mathrm{NH}_{4}^{+}\right]=\left[\mathrm{OH}^{-}\right]+\left[\mathrm{HSO}_{3}{ }^{-}\right]+2\left[\mathrm{SO}_{3}{ }^{2-}\right]+\left[\mathrm{HCO}_{3}{ }^{-}\right]+2\left[\mathrm{SO}_{4}{ }^{-}\right] .
$$

Finally, Scott and Hobbs assumed that the formulation of $\mathrm{SO}_{4}{ }^{2-}$ is an oxidation involving the $\mathrm{SO}_{3}{ }^{2-}$ ion. If $\mathrm{SO}_{4}{ }^{2-}$ is produced by a reaction between $\mathrm{SO}_{3}{ }^{2-}$ and sufficient oxygen, the rate of production of $\mathrm{SO}_{4}{ }^{2-}$ is given approximately by the first-order rate equation

$$
\frac{\mathrm{d}\left[\mathrm{SO}_{4}{ }^{2-}\right]}{\mathrm{dt}}=\mathrm{K}\left[\mathrm{SO}_{3}{ }^{2-}\right]
$$

The average carbon dioxide concentration in the gas phase was taken as $311 \mathrm{ppm}$, and the $\mathrm{CO}_{3}{ }^{2-}$ concentration was omitted in the range of interest:

\subsubsection{Model predictions}

Using the Input data listed in Table 3, the model predicted (see F1g. 1) that, when $\mathrm{NH}_{3}$ and $\mathrm{SO}_{2}$ are present in water droplets in concentratinns similar to those equal in the atmosphere, the concentration of sulfate produced after $24 \mathrm{hr}$ is about two orders of magnitude greater than the concentration that would be produced in the absence of $\mathrm{NH}_{3}$. Figure 1 does not show the case when $\mathrm{NH}_{3}$ is absent from the system. In this case, however, the model showed that, when the partial pressure of $\mathrm{SO}_{2}$ is equal to $7 \times 10^{-9} \mathrm{~atm}$, the concentration of sulfate after $24 \mathrm{hr}$ is only $0.5 \mathrm{\mu g}$ $\mathrm{cm}^{-3}$. 
Table 3. Parameters and values of the equilibrium constant of $25^{\circ} \mathrm{C}$ used in model calculations

$$
\begin{aligned}
& \mathrm{P}_{\mathrm{SO}_{2}}=7 \times 10^{-9} \text { atm }\left(20 \mu \mathrm{g} \mathrm{m}^{-3}\right) \\
& \mathrm{P}_{\mathrm{NH}_{3}}=7 \times 10^{-9} \text { atm }\left(5 \mu \mathrm{g} \mathrm{m} \mathrm{m}^{-3}\right) \\
& \mathrm{K}=1.67 \times 10^{-3} \mathrm{sec}^{-1} \\
& \mathrm{~K}_{\mathrm{hs}}=1.24 \text { moles } 1 \text { iter } \mathrm{etm}^{-1} \\
& \mathrm{~K}_{1 \mathrm{~s}}=1.27 \times 10^{-2} \text { moles } 11 \mathrm{ter}^{-1} \\
& \mathrm{~K}_{2 \mathrm{~s}}=6.24 \times 10^{-8} \text { moles liter }{ }^{-1} \\
& \mathrm{~K}_{\mathrm{ha}}=57 \text { moles liter } \mathrm{atm}^{-1} \\
& \mathrm{~K}_{1 \mathrm{a}}=1.77 \times 10^{-5} \text { moles } 11 \mathrm{ter}^{-1} \\
& \mathrm{~K}_{\mathrm{hc}}=3.4 \times 10^{-2} \text {. moles } 11 \mathrm{ter}^{-1} \mathrm{~atm}^{-1} \\
& \mathrm{~K}_{1 \mathrm{C}}=4.45 \times 10^{-7} \text { moles } 11 \mathrm{ter}^{-1} \\
& \mathrm{~K}_{2 \mathrm{C}}=4.68 \times 10^{-11} \text { moles } 1 \text { ter }^{-1} \\
& \left.\mathrm{~K}_{\mathrm{w}}=1.008 \times 10^{-14} \text { (moles 11ter }{ }^{-1}\right)^{2}
\end{aligned}
$$

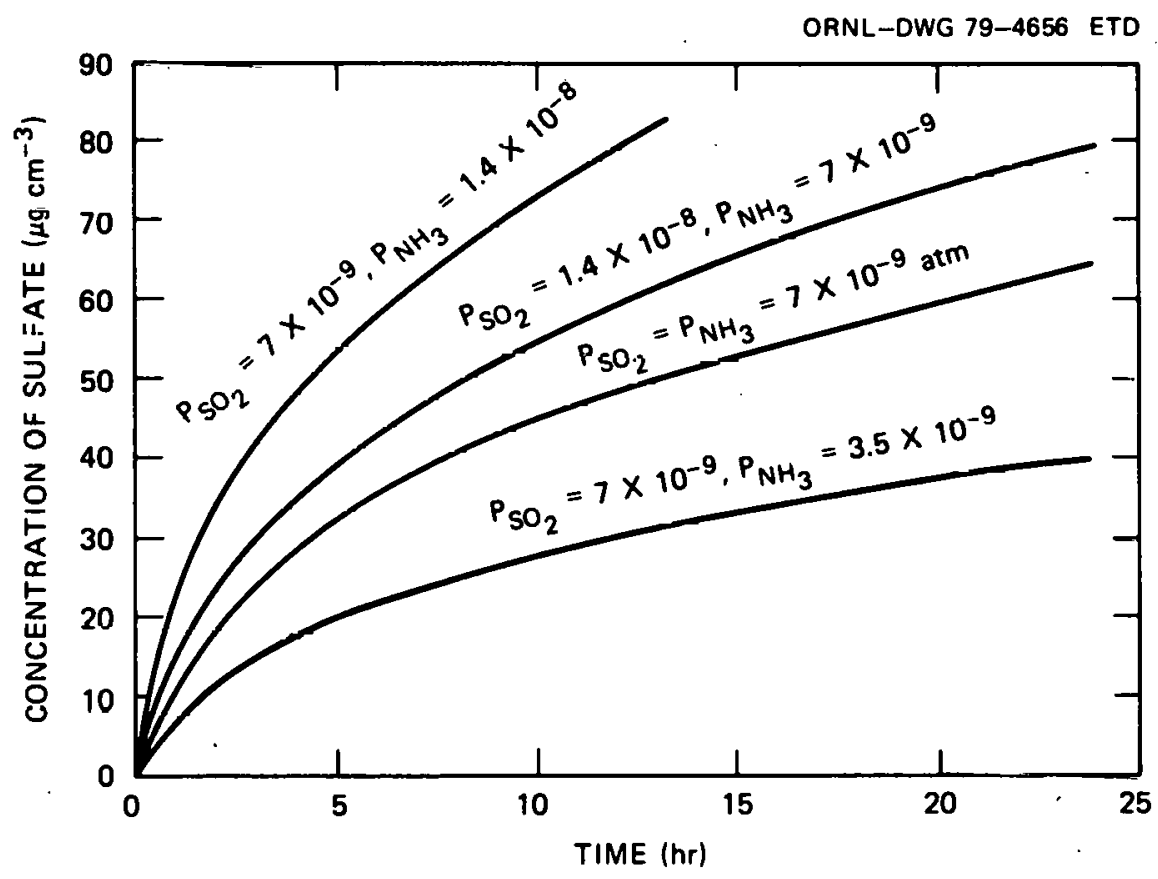

Fig. 1. Theoretical results for the concentration of sulfate in water drops as a function of time. Source: W. D. Scott and P. V. Hobbs, F1g. 1, p. 56 in "The Formation of Sulfate in Water Droplete," 7 . Atmos. Sciences 24 (1967). 


\subsubsection{Discussion of the model}

The predicted results by the Scot't and Hobbs model suggested that ammonia catalyzes the reaction for ammonium sulfate production. When Scott and Hobbs compared their predicted results with those of experiments by Junge and Ryan, 21 a qualitative agreement was found. Junge and Ryan showed that the concentration of sulfate in water reached a limiting value after about $5 \mathrm{hr}$. They also observed a direct proportionality between the limiting value of the sulfate concentration and the partial pressure of the $\mathrm{SO}_{2}$ in the atmosphere. Although the general shapes of the predicted curves shnw in Fig. 1 are simflar to the experimental curves of Junge and Ryan, the Scott and Hobbs model does not show the conceillration of sulfate reaching a limiting value even after $24 \mathrm{hr}$; neither does the model predict a direct proportionality between the concentration of sultatc and Llie partial pressure of the $\mathrm{SO}_{2}$. These discrepancies may result because, in the experiments of Junge and Ryan, $\mathrm{FeCl}_{2}$ was used as a catalyst.

On the liquid-phase oxidation, the model assumed that formation of $\mathrm{SO}_{4}{ }^{2-}$ in water drops is due to $\mathrm{Sn}_{3}{ }^{2-}$ oxtdatiull. Thị assumption was used widely by the other models, but the chemical processes involved are not well understood. In the Scott and Hobbs model, the oxidation rate was extrapolated from Van den Heuval and Mason's ${ }^{22}$ experiment that has concentrations of $\mathrm{SO}_{2}$ and $\mathrm{NH}_{3}$ much larger than those found in the atmosphere.

\subsection{Model by Hales, Wolf, and Dana - 1973}

\subsubsection{Introduction}

The Hales et al. models,23,24 which are of various complexities, have been constantly updated and revised for a variety of applications. A theoretical study of gas scavenging by rain, developed by Hales, 25 is used as a basis for the general description of the model. However, only the results predicted by a linearized version of EYAEC are reviewed. This model, a special application of the generalized derivation from the mass-. transfer theory, is one of the physical models widely used for predicting washout. It describes reversible gas-sorption behavior and liquid-phase 
mixing but does not include the chemical reaction. The model assumes vertical rainfall, constant transport, and solubility properties and employs a Pasquill-Gifford bivariate-normal plume for sulfur dioxide dispersion. With these assumptions, an analytical solution is derived. The predicted ground-1evel raindrop concentration of $\mathrm{SO}_{2}$ is compared with field data.

\subsubsection{Model description}

According to Hales, ${ }^{25}$ the interaction between rain and air pollutants may be described in terms of a two-phase system. The equations of continuity for the air pollutant in the gas phase and the pollutant in rain (liquid phase) may be expressed by

$$
\frac{\partial \rho_{A y}}{\partial t}=-\left(\nabla \cdot \rho_{A y} \bar{v}_{A}\right)-w+r_{A y},
$$

and

$$
\frac{\partial \rho_{\mathrm{Ax}}}{\partial t}=-\frac{4 \pi \mathrm{N}_{\mathrm{o}}}{3}\left[\nabla \cdot \int_{0}^{\infty} \mathrm{a}^{3} \mathrm{f}(\mathrm{a}) \overline{\mathrm{v}}_{\mathrm{t}} \mathrm{c}(\mathrm{a}) \mathrm{da}\right]+\mathrm{w}+\mathrm{r}_{\mathrm{Ax}},
$$

where $\rho_{A x}$ and $\rho_{A y}$ denote molar densities of 1iquid- and gas-phase pollutant $A$, respectively. Similary, $\bar{v}_{A}$ and $\bar{v}_{t}$ denote average velocity vectors for the pollutant in air and in rain, and $r_{A x}$ and $r_{A y}$ are the corresponding terms for generation of the pollutant by chemical reaction. The tille rate of gain of pollutant mass in the liquid phase by washout is defined by $w$, per unit volume of space. No represents the concentration of drops in rain, and $c$ is the concentration in the drop. Note that w appears in both equations and provides a coupling mechanism. For conditions of spherical, noninteracting raindrops, w can be given as

$$
\begin{aligned}
w & =-4 \pi N_{0} \int_{0}^{\infty} a^{2} f(a) N_{A o} d a \\
& =4 \pi N_{0} \int_{0}^{\infty} a^{2} f(a) K_{y}(a)\left(y_{A b}-H^{\top}(\cdot) d a,\right.
\end{aligned}
$$


where $\mathrm{N}_{A o}$ denotes the average flux of material from the surface of a raindrop with radius a.

The model further assumed that the system is linear in the sense that the mass-transfer coefficient $K_{y}$ and the effective Henry's law constant $\mathrm{H}^{-}$are constant with concentration. In addition, it assumed that (1) a steady state exists, (2) chemical reaction is negligible, (3) the washout rate is small compared with the divergence term in Eq. (21), and (4) all raindrops fall through vertical trajectories.

The above assumptions effectively decouple Eqs. (21) and (22) so that an expression for flux of rajnborne pollutant (moles $\mathrm{cm}^{-2} \mathrm{sec}^{-1}$ ) through an incremental area at the ground can be written as

$$
F_{0}=\frac{4 \pi N_{0}}{3} \int_{0}^{\infty} a^{3} f(a) v_{z} c(a, 0) d u
$$

Because of the assumption of noninteraction between drops, an equation pertaining to any individual raindrop san he derdved in terus of the liquid-phase concentration

$$
\frac{d c}{d z}-\frac{3 K_{y}}{v_{z}^{a}}\left(x_{A b}-H^{-} C\right)
$$

where $X_{A b}$ denotes mole fraction of pnllutant in gas-phase bulk, and $z$ is the vertical distance above the ground. This may be intcgrated wilh respect to $z$ to obtain

$$
c(a, 0)=\frac{3 K_{y}}{v_{z}{ }^{a}} \int_{\infty}^{0} \exp \left(\frac{3 K_{y} H^{\prime} z}{v_{z}^{a}}\right) x_{\Lambda b} d z
$$

at ground level. 
By using a Pasquill-Gifford bivariate-normal plume equation to describe $\chi_{A b}$, the integration can be carried out to obtain

$$
\begin{aligned}
& c(a, 0)=-\frac{Q F \xi}{2 \sqrt{2 \pi} \sigma_{y}^{\bar{u}}} \exp \left(-\frac{y^{2}}{2 \sigma_{y}^{2}}+\frac{\sigma^{2} \zeta^{2}}{2}\right) \\
& \times\left\{\exp (\zeta h)\left[1-\operatorname{erf}\left(\frac{-\sigma_{z}^{2} \zeta-h}{\sigma_{z} \sqrt{2}}\right)\right]\right. \\
&\left.+\exp (-\zeta h)\left[1-\operatorname{erf}\left(\frac{-\sigma_{z}^{2} \zeta h}{\sigma_{z}^{\sqrt{2}}}\right)\right]\right\},
\end{aligned}
$$

where

$$
\begin{aligned}
& \zeta=\frac{3 K_{y} H^{\prime}}{v_{z}^{a}}, \\
& \xi=\frac{3 K_{y}}{v_{z}^{a}},
\end{aligned}
$$

and $F$ is a factor included to account for depletion of the plume by washout.

Regarding the mass-transfer coefficients for gas absorption by falling drops, the model considers two limiting conditions - those posed by gas-phase limited and by stagnant drop behaviors. The gas-phase masstransfer coefficlent $k_{y}$ is estimated from the Frössling equation

$$
\frac{2 \mathrm{k}_{\mathrm{y}} \mathrm{a}}{\mathrm{D}_{\mathrm{Ay}} \mathrm{C}_{\mathrm{y}}}=2+0.6\left(\frac{2 \mathrm{av}_{z}}{\nu}\right)^{1 / 2}\left(\frac{v}{\mathrm{D}_{\mathrm{Ay}}}\right)^{1 / 3} \text {, }
$$


where

$$
\begin{aligned}
c_{y} & \left.=\text { total concentration in gas-phase (mole } \mathrm{cm}^{-3}\right), \\
D_{A y} & =\text { diffusivity of } \mathrm{SO}_{2} \text { in air }\left(\mathrm{cm}^{2} \mathrm{sec}^{-1}\right), \\
k_{y} & =\text { gas-phase mass-transfer coefficient }\left(\text { mole } \mathrm{cm}^{-2} \mathrm{sec}^{-1}\right), \\
\nu & =\text { kinematic viscosity of air }\left(\mathrm{cm}^{2} \mathrm{sec}^{-1}\right) .
\end{aligned}
$$

For stagnant drop conditions, the 1iquid-phase mass-transfer coefficient is calculated using the formula describing diffusion into a sphere:

$$
\mathrm{k}_{\mathrm{x}}=\frac{5 \mathrm{D} A \mathrm{Ax}^{\mathrm{c}} \mathrm{x}}{\mathrm{a}}
$$

where

$$
\begin{aligned}
\mathrm{c}_{\mathrm{x}} & =\text { pollutant concentration ili liquid phase }(\text { mole liter } \\
\mathrm{D}_{\mathrm{Ax}} & =\text { molecular diffusivity of } \mathrm{SO}_{2} \text { in water }\left(\mathrm{cm}^{2} \mathrm{sec}^{-1}\right) \\
\mathrm{k}_{\mathrm{x}} & =\text { liquid-phase mass-transfer coefficient }\left(\operatorname{mole~} \mathrm{cm}^{-2} \mathrm{sec}^{-1}\right)
\end{aligned}
$$

The overall coefficient for the limiting cases is then given by

$$
\frac{1}{k_{y}}=\frac{H^{\prime} c_{x}}{k_{x}}+\frac{1}{k_{y}} .
$$

\subsubsection{Model predictions}

Hales et al. used their linear model to predict wasliuut concentrations in rain by a set of input data (Table 4) covering source, dispersion, and transport properties pertinent to a controlled experiment conducted at Quillayute, Washington, during March 1971. Two methods were employed in washout concentration calculations: (1) a distrihuter system was used by performing a number of calculations using Eq. (27) for selected drop sizes and then combining the contributions to evaluate a mixed-mean concentration corresponding to a collected rain sample; (2) a mass-mean diameter method was used by lumping the raindrop statistics into one representative drop size and subsequently solving Eq. (27) once. Calculated results are shown in Fig. 2, along with the measured concentration depicted by vertical bars. Concentrations calculated on the basis of the 
Table 4. Data used in model calculations

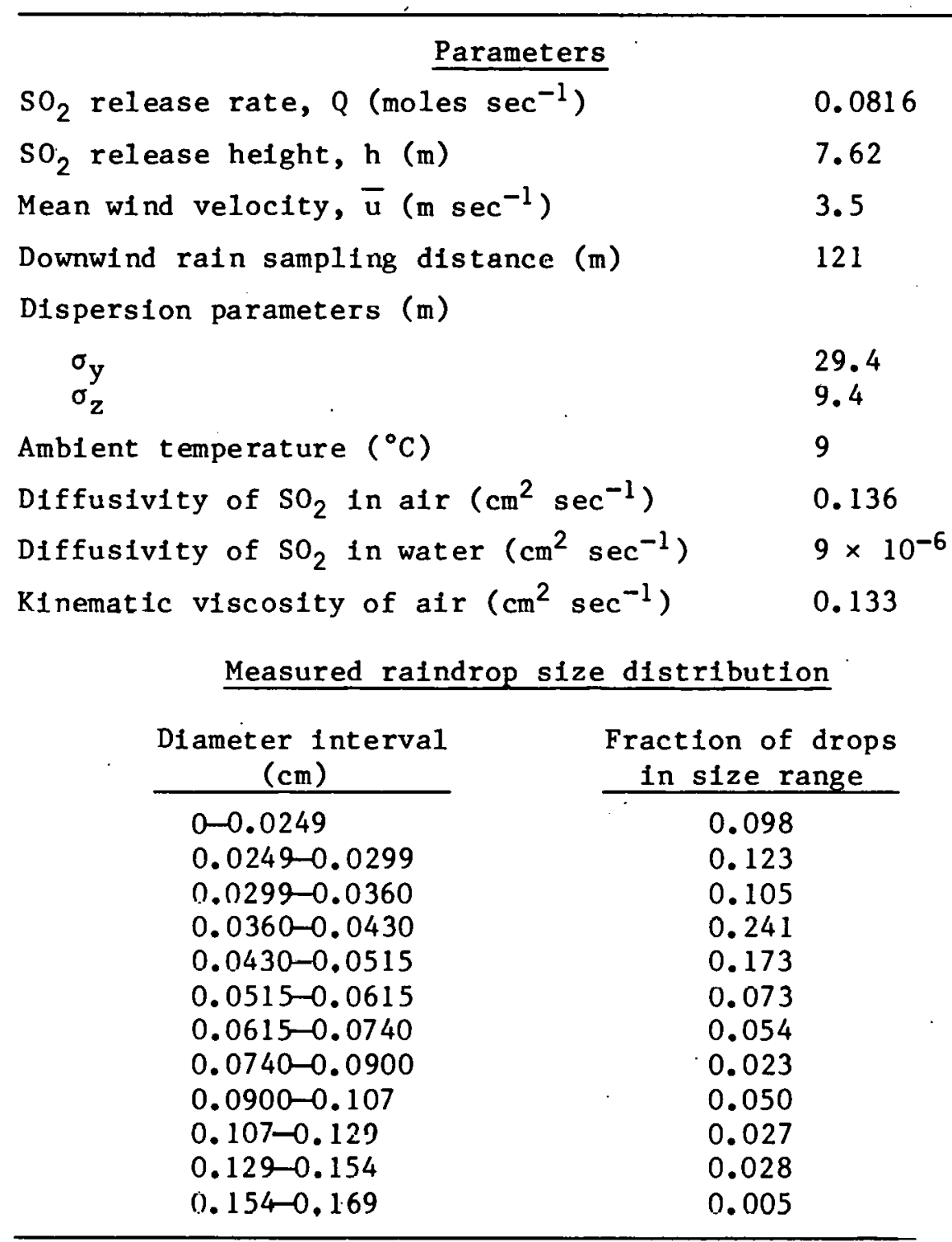

well-mixed drop hehavior were denoted by solid curves, while those based on the stagnant drop assumption were shown by the broken curves.

Figure 2 pertains to a single experiment and therefore provides only a partial predictive capability of the model. For a better comparison between the theory and experiment, a more complete test is shown in Fig. 3, which is a plot of predicted washout rates vs those measured for $\mathrm{SO}_{2}$ during 


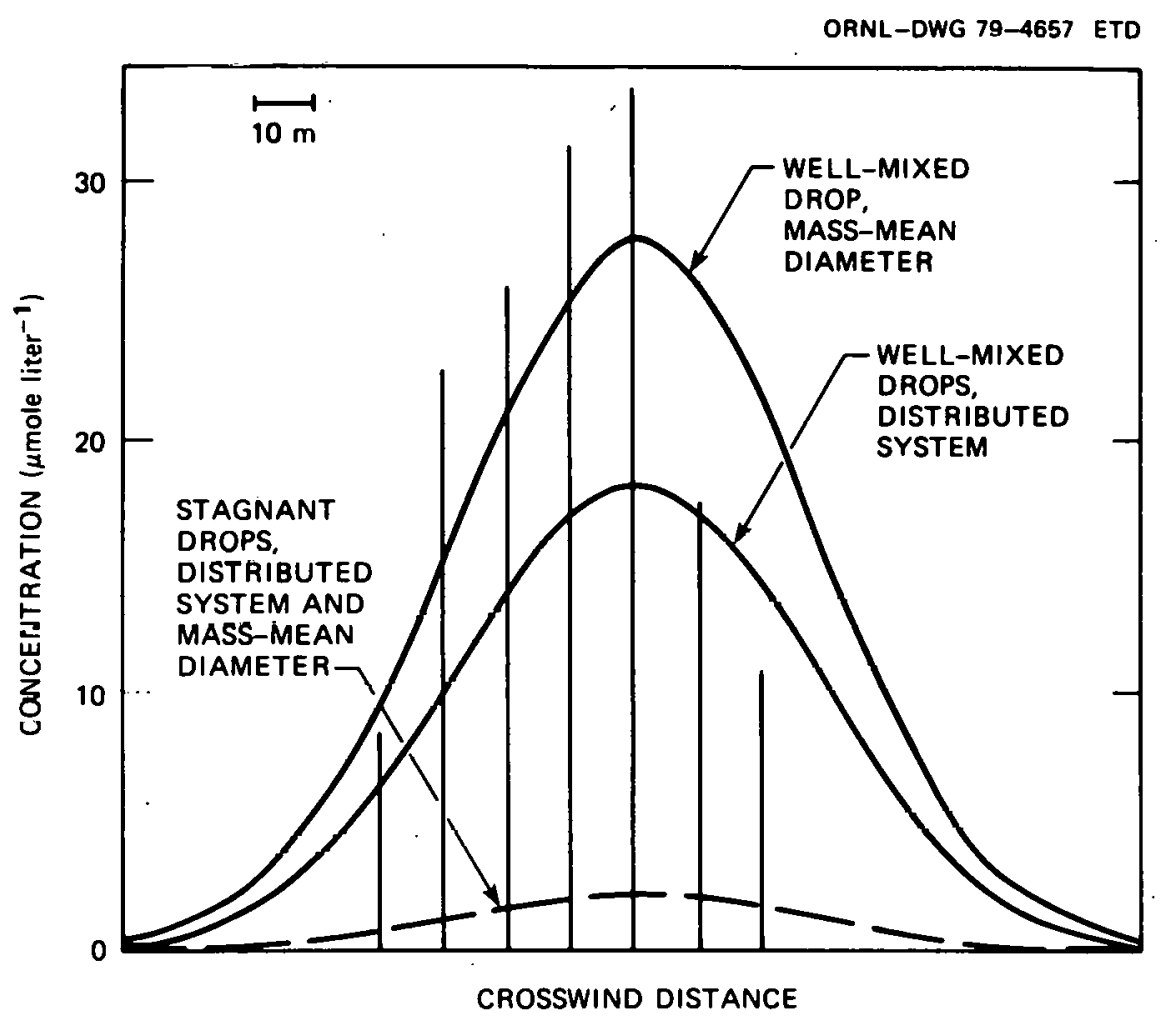

Fig. 2. Observed crosswind distribution of $\mathrm{SO}_{2}$ concentrations in rain compared with those predicted by llnear washout model. Source: J. M. Hales, M. A. Wolf, and M. T. Dana, Fig. 2, p. 295 in "A Linear Model for Predicting the Washout of Pollutant Gases from Industrial Plumco," AIChE' 19 (197.3).

a number of field experiments. The mass-mean diameter method was used. Limits on the horizontal lines correspond to the liulls of well-mixed and 3 tagnail drop behavior.

\subsubsection{Discussion of the model}

The physical model of Halca et al., quice sophisticated in its treatment of mass-transfer behavior, was tested with field data. The following discussion highlights the important model features.

Regarding the $\mathrm{SO}_{2}$ solubility, because there arc limited data pertaining to the solubility of trace concentration of $\mathrm{SO}_{2}$ in water, Hales et al. extrapolated from data obtained at much higher concentration to the range of interest. Whether this is justifiable must be resolved by more experimental work. 


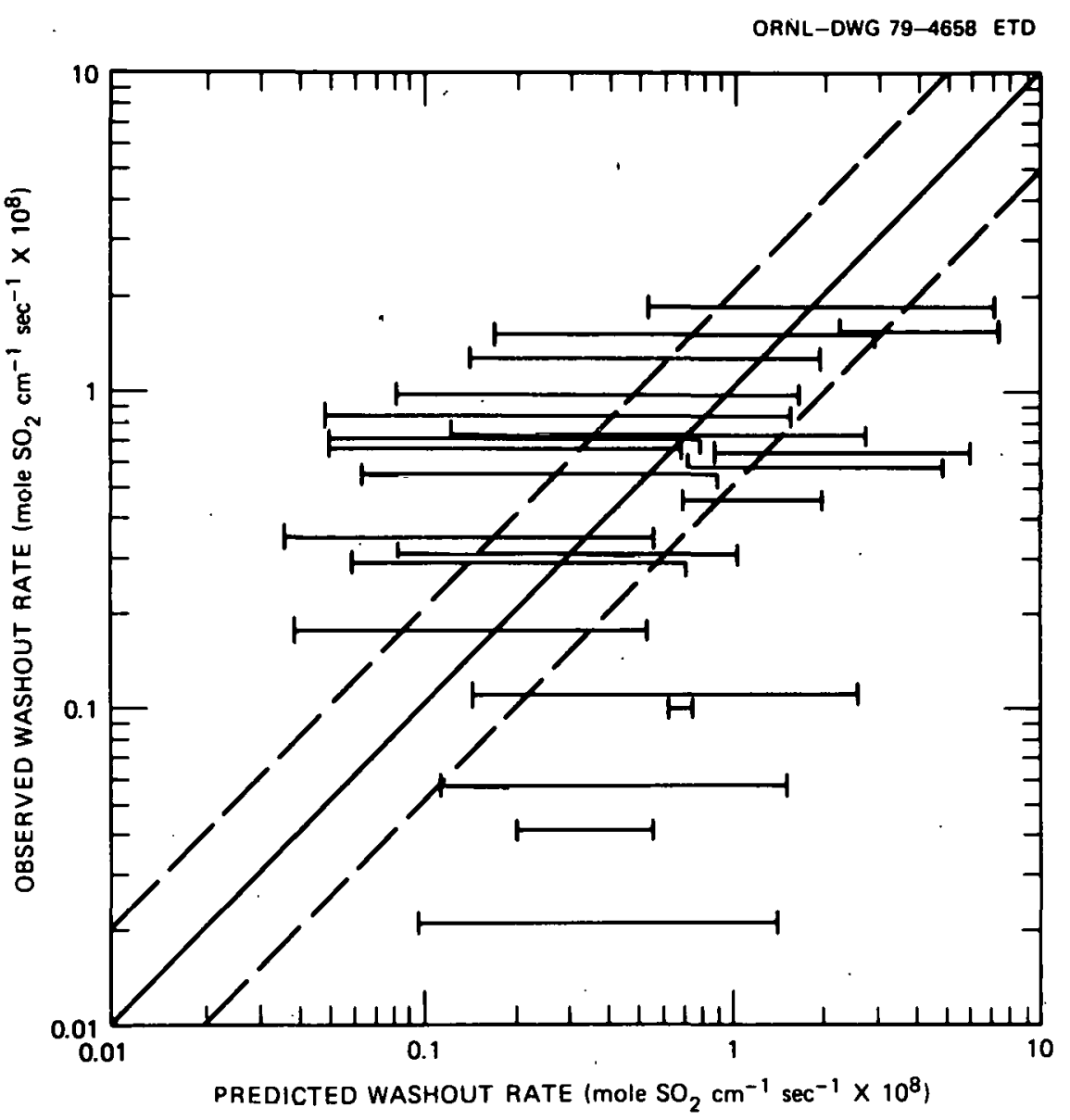

Fig. 3. Comparison of observed washout rates with those predicted using the mass-mean raindrop size in conjunction with the linear model. Dashed lines denote deviation by a factor of 2. Source: J. M. Hales, M. A. Wolf, and M. T. Dana, Fig. 4, P. 296 in "A Linear Model for Predicting the Washout of Pollutant Gases from Industrial Plumes," AIChE 19 (1973).

As pointed out by Hales et al., the solubility of $\mathrm{SO}_{2}$ in water depends on concentration in a highly nonlinear manner. The curves in Fig. 4 indicate a rather strong dependence of solubility on $\mathrm{pH}$. Such dependence is important for two reasons: (1) this would lead one to expect a general lowering of measured washout rates with decreasing $\mathrm{pH}$, and (2) the dependence would be expected to decrease the effectiveness of washout in the plume, because the plume itself contains acid-forming material (e.g., sulfates, nitrates) which could serve to lower $\mathrm{pH}$. 


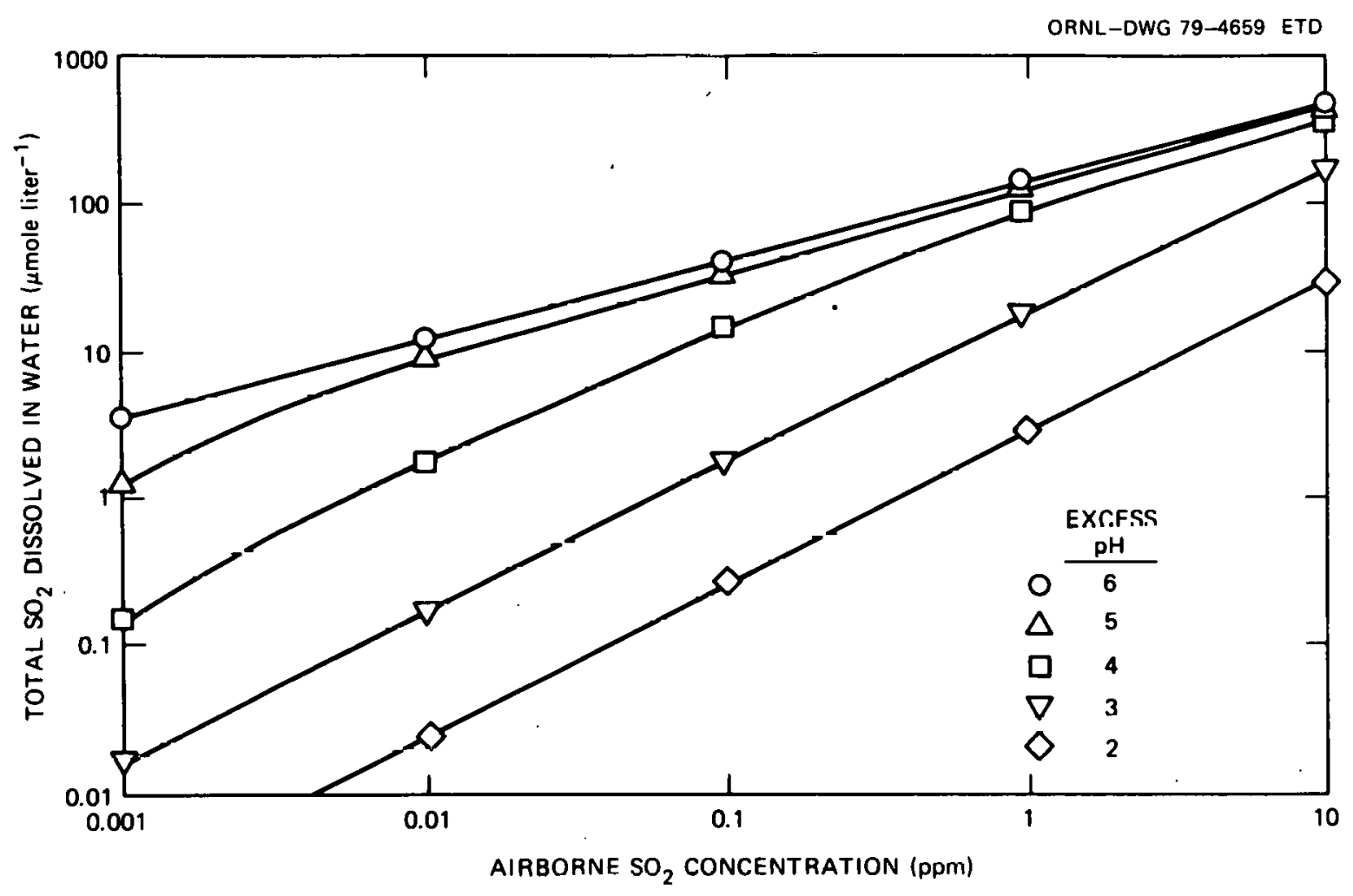

Fig. 4. Estimated solubility of sulfur dioxide in water. Source: J. M. Hales, J. M. Thorp, and M. A. Wolf, F1g. 3.10, p. 59 1n Field Investigation of Sulfur Dioxide Washout from the Plume of a Large CoalFired Power Plant by Natural Precipitation, NTIS Report PB-203,129 (1971),

Those results shown in Fig. 2 must be considered. For the wellmixed drop behavior, calculations based on the method of a mass-mean dlameter provide closest agreement with peak concentration valuss. Total washout rates that are proportional to areas heneath the curvca, however, are matched more closely by the method of distributed system calculations. Conversely, for the stagnant drop behavior, calculations by either the. mass-mean dlameter method or the distributed drop-size system showed similar results and, obviously, provided a low estimate of true behavior in this example.

For the collective prediction shown in Fig. 3, the results indicate a rather wide scatter. Limits on the horizontal lines correspond to the limits of the stagnant drop behavior and the well-mixed assumption. Discrepancies between the theory and experiment may be caused by a number of 
assumptions that have been incorporated into the model. These assumptions include the limiting models of mass-transfer behavior, a Gaussian plume dispersion model, the linearized solubility behavior, and a linear system composed of vertically falling, spherical, noninteracting drops of static size distribution.

Hales et al. further noted that all data presently available for comparison pertain to relatively close distances from the source. At much greater distances, significant plume modification may occur from dry deposition and other effects, thus requiring creation of a modified equation based on the altered distribution of the plume.

\subsection{Model by Dana, Drews, Glover, and Hales - 1976}

\subsubsection{Introduction}

The Scavenging Model Incorporating Chemical Kinetics (SMICK) developed by Dana et $a 1.26$ is an extension of EPAEC, ${ }^{23}$ which is reviewed in Sect. 3.2. While EPAEC focuses on the scavenging of a single plume constituent only (1.e., $\mathrm{SO}_{2}$ washout), SMICK describes the wet removal of multiple reactive components. The model assumes the liquid-phase $\mathrm{SO}_{2}$ oxidation mechanism of Scott and Hobbs ${ }^{20}$ with catalytic action of ammonia. The SMICK nodel, a combination of physical and chemical models, predicts liquid-phase chemical reaction and possible desorption of multiple plumebound pollutants as they interact with falling raindrops and are ulti-.. Illately deposited on the ground.

\subsubsection{Model description}

SMICK is a combined physical and chemical model. The part that involves physical modeling is similar to that of EPAEC, already reviewed in Sect. 3.2. The part that involves chemical modeling is identical to that of Scutt and Hobbs, reviewed in Sect, 3.1.

\subsubsection{Mode1 predictions}

Dana et al. used SMICK to predict the $\mathrm{SO}_{2}$ and $\mathrm{SO}_{4}{ }^{2-}$ concentration in rainwater at groind level for a number of cases. Input data are presented in Table 5 and Fig. 5. Table 5 provides actual experimental input data 
Table 5. Basic experimental data from Centralia as izput for mociel zalculations

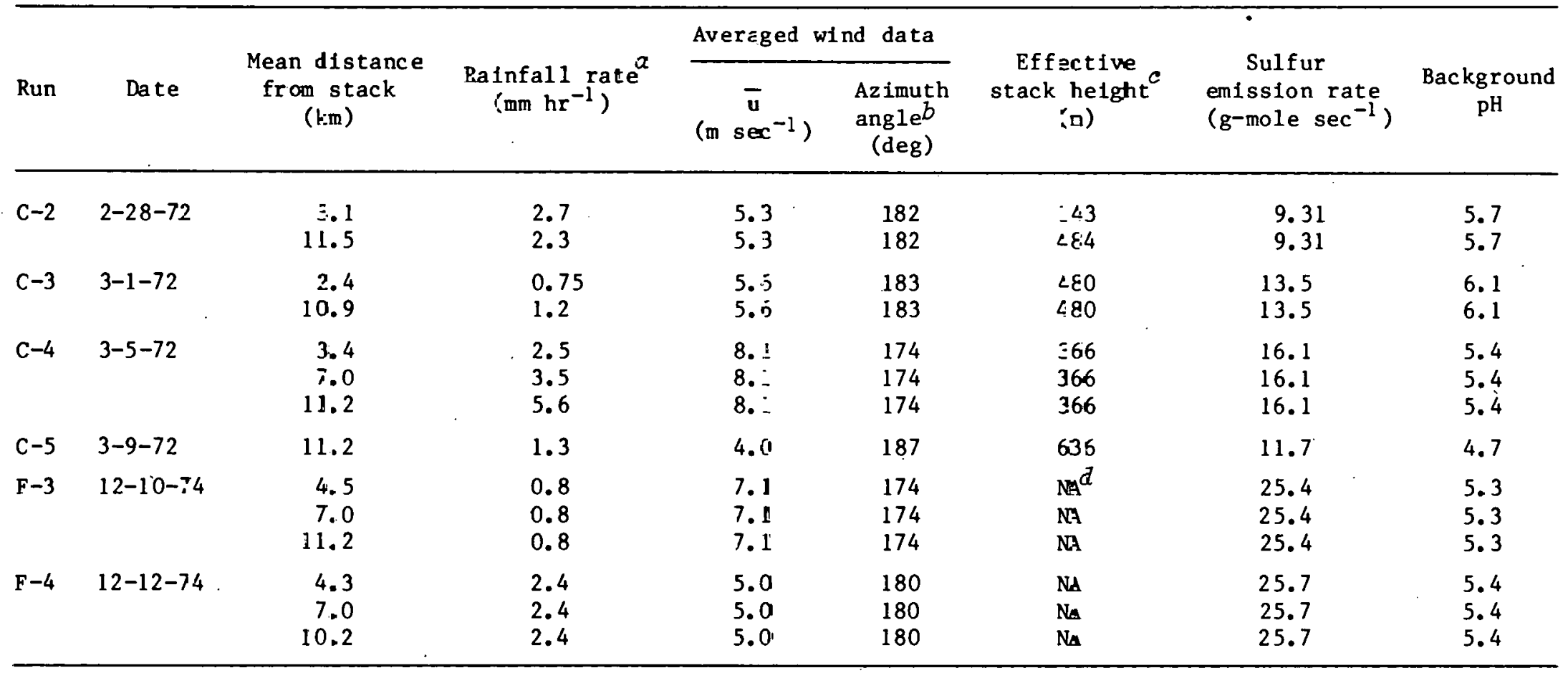

Average of all collectors on sampling 1ine.

$b$ From true north.

$c$ At sour:e, method of Briggs is used.

$d$ Not availlable. 


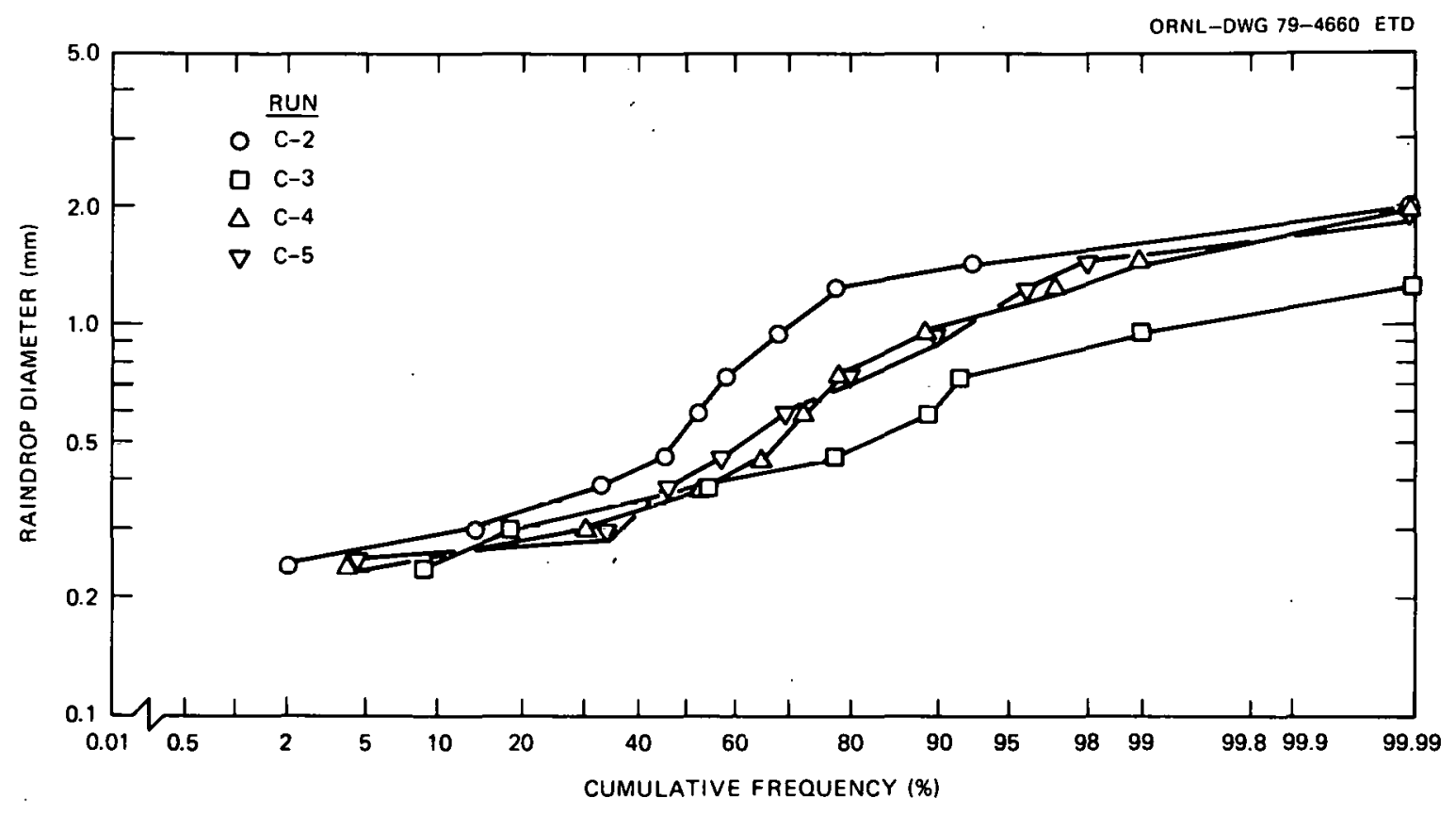

Fig. 5. Cumulative frequency of raindrop size distribution for Centralia.

for two Centralia field series, and Fig. 5 summarizes raindrop size distribution in which the mafority of runs involved significant collection of frontal-type precipitation over time periods varying from 1.5 to $5 \mathrm{hr}$.

The calculations, shown in Figs. 6 and 7, were performed for values of $\mathrm{K}=0.0017 \mathrm{sec}^{-1}$, an oxidation rate suggested from an experiment by Van Hen Heuval and Mason ${ }^{22}$ at $\mathrm{P}_{\mathrm{NH}_{3}}=1 \mathrm{ppb}$, a typical background level for the Centralia area. Furthermore, all calculations employed the Smith and Singer ${ }^{27}$ formula for the plume standard deviations. Both in predictions and measurements, $\mathrm{SO}_{2}$ concentration is referred to the sum of the concentration of aqueous-phase $\mathrm{SO}_{2}, \mathrm{HSO}_{3}-$, and $\mathrm{SO}_{3}{ }^{2-}$.

Figures 6 and 7 , showlity the ground-lcvel concentration of $\mathrm{SO}_{2}$ and $\mathrm{SO}_{4}{ }^{2-}$, respectively, as a function of downwind distance, were plotted from tabulated values predicted by SMICK and. observed by Dana et al. for a number of runs. Predicted values for $\mathrm{SO}_{4}{ }^{2-}$ are in the same order as those of observed values, but the predicted $\mathrm{SO}_{2}$ exceeds that observed by more than one order of magnitude. 


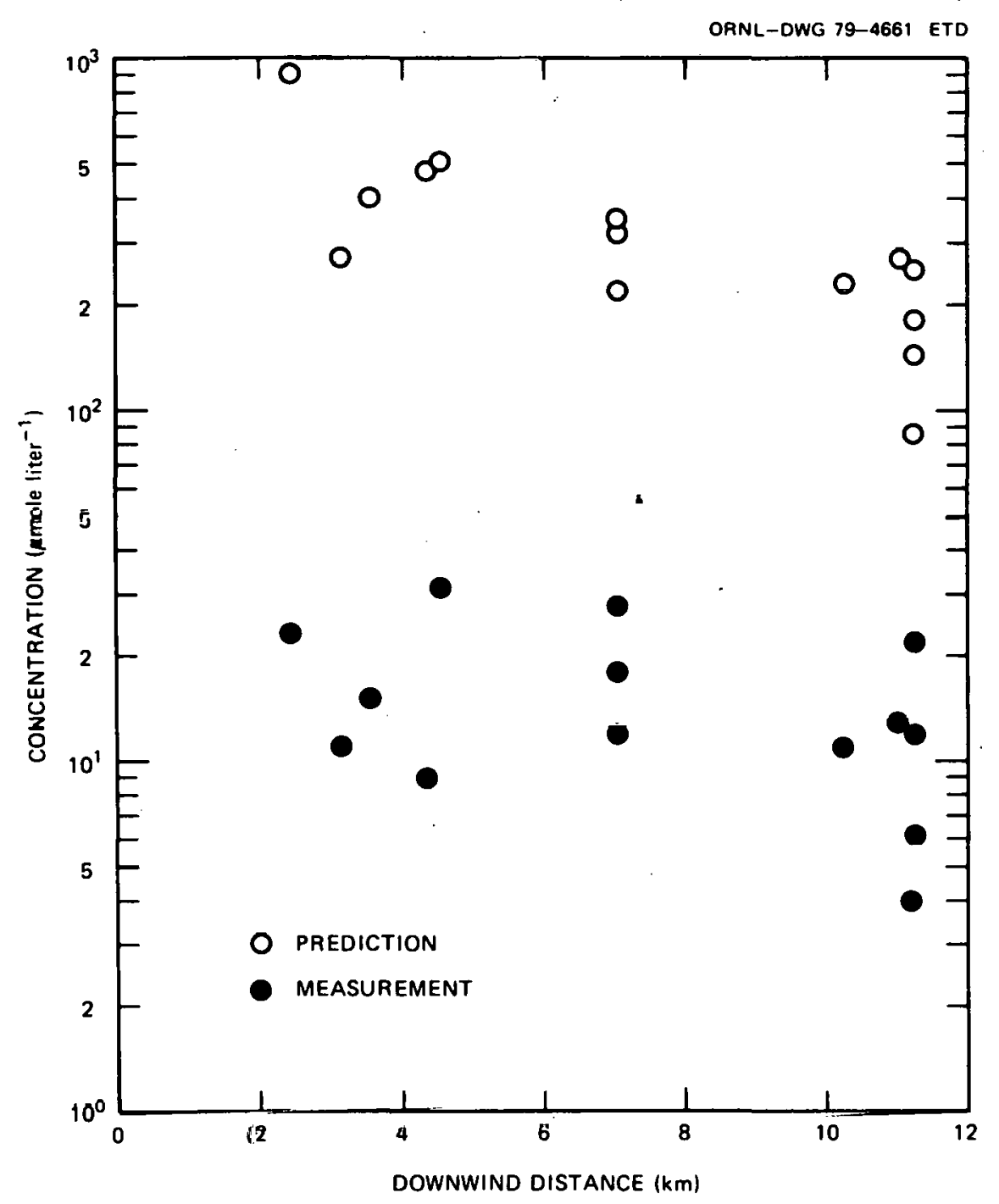

Fig. 6. Predicted (by SMICK) and measured (at Centralia) plume centerline rainwater $\mathrm{SO}_{2}$ concentration $\left[\left(\mathrm{SO}_{2}\right)_{\mathrm{aq}}+\mathrm{HSn}_{3}{ }^{-}+\mathrm{SO}_{3}{ }^{2-}\right]$ a a function of downwind distance.

\section{3 .4 Dlucusion of the model}

The SMICK model employed a liquid-phase oxidation catalyzed by ammonia, a mechanism proposed by Scott and Hobbs. Three assumptions were Idencified regarding the use of this mechanism in the model: constant ammonia solubility, fixed equilibrium constants, and constant oxidation rate. First, the ammonia solubility in water, like $\mathrm{SO}_{2}$, is nonlinear in character, and the use of a constant solubility in the model extrapolated 


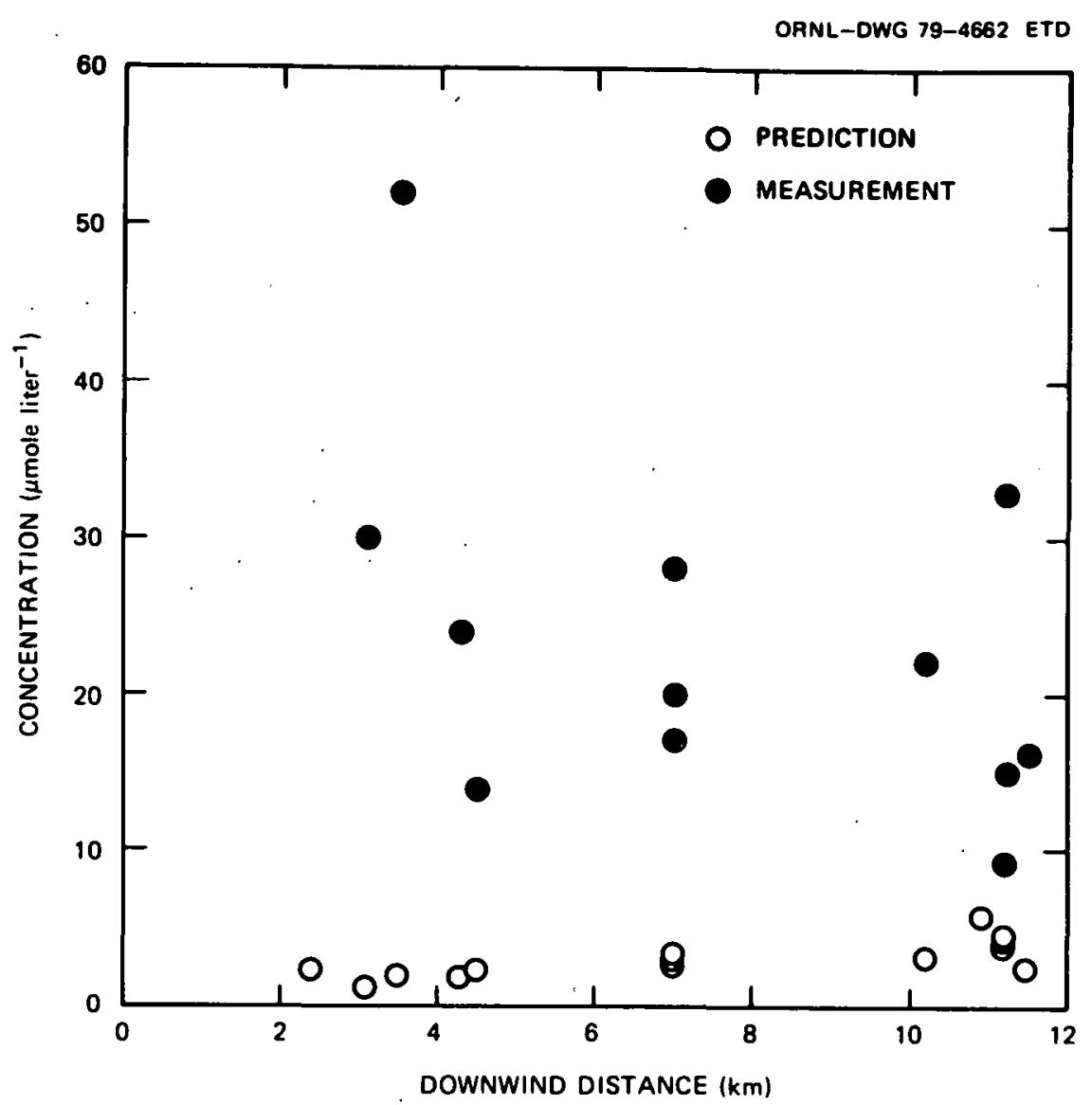

Fig. 7. Predicted (by SMICK) and measured (at Centralia) plume centerline rainwater $\mathrm{SO}_{4}{ }^{2-}$ concentration as a function of downwind distance.

from data obtained at much higher gas-phase concentrations required laboratory verification. Second, the equilibrium constants involved in intermediate steps for concentration calculations are temperature dependent. Fixed values at $25^{\circ} \mathrm{C}$ used in the model need to be modified. Third (probably the most important assumption made in the model is the $\mathrm{K}$ value), the oxidation rate at the final step concerning the conversion of $\mathrm{SO}_{3}{ }^{2-}$ to $\mathrm{SO}_{4}{ }^{2-}$, which is highly controversial, needed to be reexamined. A laboratory experiment about the $K$ value has been studied in detail recently by Beike, Lamb, and Muller. 28

The results presented in Figs. 6 and 7 serve as a test of the ammonia model's abilfty to account for the observed values of rain concentrations of $\mathrm{SO}_{2}$ and $\mathrm{SO}_{4}{ }^{2-}$ at ground level. In Fig. 6, the concentration is plotted vs downwind distance. The large predicted concentrations of dissolved 
$\mathrm{SO}_{2}$ result directly from the increased alkalinity because the solubility of $\mathrm{SO}_{2}$ is a strong decreasing function of excess $\mathrm{H}^{+}$concentration. In Fig. 7, the predicted values for $\mathrm{SO}_{4}{ }^{2-}$ concentration are the same order of magnitude as those observed, but the method by which they are derived is inappropriate. Clearly, the presence of ammonia is required in this mechanism for any significant sulfate to appear, but the process also leads to rather large ammonium ion concentration and high $\mathrm{pH}$; a partial list of their results (including $\mathrm{NH}_{4}^{+}$and $\mathrm{H}^{+}$concentration) is shown in Table 6.

Tabie 6. Comparison of predicted values by SMICK with field measurement

[Concentration $\left(\mathrm{g}-\mathrm{moles} \mathrm{cm}^{-3}\right) \times 10^{9}$ ]

\begin{tabular}{lllll}
\hline \multicolumn{2}{c}{ Predicted } & & \multicolumn{2}{c}{ Observed } \\
\cline { 5 - 5 } $\mathrm{NH}_{4}{ }^{+}$ & $\mathrm{H}^{+}$ & & $\mathrm{NH}_{4}{ }^{+}$ & $\mathrm{H}^{-1}$ \\
\hline 331 & 5.0 & & 2.4 & 79 \\
371 & 4.0 & & 3.6 & 79 \\
274 & 2.5 & & 2.5 & 63 \\
497 & 5.0 & & 19.5 & 32 \\
336 & 3.7 & & 5.0 & 32 \\
249 & 2.5 & 6.5 & 32 \\
\hline
\end{tabular}

\subsection{Model by Hill and Adamowicz - 1977}

\subsubsection{Introduction}

Like SMICK, the Hill and Adamowicz model ${ }^{19}$ combines the physical and chemical approach but is different from the assumption in the $\mathrm{SO}_{2}$ 11quidphase oxidation mechanism. This model assumed a two-layercd atmosphere with clean air lying above polluted air. It introduced a bisulfite liquidphase oxidation mechanism for sulfate ion production and further predicted the time scale for $\mathrm{SO}_{2}$ removal as a function of atmospheric $\mathrm{SO}_{2}$ concentration, initial rainwater $\mathrm{pH}$, droplet size, and the raindrops' fall distances. 


\subsubsection{Model description}

H111 and Adamowicz's model consists of a number of processes regarding physical and chemical reactions in a falling raindrop. These processes are Henry's law, ion equilibrium, electroneutrality, mass transport between alr and raindrops, and liquid-phase oxidation.

Henry's law for ralndrops' $\mathrm{SO}_{2}$ uptake is assumed by $\mathrm{HIll}$ and Adamowicz :

$$
\left[\mathrm{SO}_{2}\right]=x_{\mathrm{SO}_{2}}^{*} / \mathrm{H}
$$

where

$$
\begin{aligned}
\mathrm{H} & =\text { Henry's law constant, } \\
{\left[\mathrm{SO}_{2}\right] } & =\text { liquid-phase } \mathrm{SO}_{2} \text { concentration in raindrops, } \\
\chi_{\mathrm{SO}_{2}}^{*} & =\text { equilibrium gas-phase } \mathrm{SO}_{2} \text { concentration. }
\end{aligned}
$$

Like most other models, equilibria of chemical reactions subjected to electroneutrality conditions are included in the model

$$
\mathrm{SO}_{2}+\mathrm{H}_{2} \mathrm{O} \leftrightharpoons \mathrm{H}^{+}+\mathrm{HSO}_{3}^{-} \text {, }
$$

with

$$
\mathrm{K}_{1}=\frac{\left[\mathrm{H}^{+}\right]\left[\mathrm{HSO}_{3}{ }^{-}\right]}{\left[\mathrm{SO}_{2} \cdot \mathrm{H}_{2} \mathrm{O}\right]} \text {, }
$$

and

$$
\left[\mathrm{H}^{+}\right]=\left[\mathrm{HSO}_{3}{ }^{-}\right]+2\left[\mathrm{SO}_{4}{ }^{--}\right]+\left[\mathrm{H}_{\mathrm{EX}}^{+}\right]+\frac{\mathrm{K}_{\mathrm{W}}}{\left[\mathrm{H}_{\mathrm{EX}}^{+}\right]} \text {, }
$$

where

$$
\begin{aligned}
{\left[\mathrm{H}^{+}\right] } & =\text {hydrogen ion concentration in ralindrops, } \\
{\left[\mathrm{HSO}_{3}{ }^{-}\right] } & =\text {bisulfite ion concentration in raindrops, } \\
{\left[\mathrm{H}_{\mathrm{EX}}^{+}\right] } & =\text {background excess acid or base in raindrops, } \\
\mathrm{K}_{1} & =\text { dissociation constant at equilibrium, } \\
\mathrm{K}_{\mathrm{W}} & =\text { dissociation constant for water, } \\
{\left[\mathrm{SO}_{4}{ }^{2-}\right] } & =\text { sulfate ion concentration in raindrops. }
\end{aligned}
$$


The total sulfur compound concentration in a raindrop is given by

$$
\left[\mathrm{S}_{\mathrm{T}}\right]=\left[\mathrm{SO}_{2}\right]+\left[\mathrm{HSO}_{3}{ }^{-}\right]+\left[\mathrm{SO}_{4}{ }^{-}\right]
$$

where $\left[S_{T}\right]$ is the total sulfur content in raindrops. Equilibria involvIng bisulfate ion and sulfuric acid are neglected in the model.

The rate of accumulation of all compounds of sulfur in each falling drop is assumed by Hill and Adamowicz to be equal to the rate of mass transfer of $\mathrm{SO}_{2}$ across a fictitious laminar air film surrounding each dron:

$$
u_{z} \frac{d\left[S_{T}\right]}{d z}=-\frac{3 k}{R}\left(x_{S_{2}}-x_{S_{2}}^{*}\right)
$$

where

$$
\begin{aligned}
3 / \mathrm{R} & =\text { area-to-volume ratio of the drop, } \\
\mathrm{k}_{\mathrm{g}} & =\text { gas-phase mass transfer coefficient, } \\
\mathrm{R} & =\text { drop radius, } \\
\mathrm{u}_{z} & =\text { drop terminal velocity, } \\
z & =\text { fall distance, } \\
\mathrm{XSO}_{2} & =\text { amblent gas-phase } \mathrm{SO}_{2} \text { concentration. }
\end{aligned}
$$

Finally, H1Il and Adamowicz assume that the sulfate ion is produced by a reaction that is first order with respect to the bisulfite ion:

$$
\mathrm{u}_{\mathrm{z}} \frac{\mathrm{d}\left[\mathrm{SO}_{4}{ }^{--}\right]}{\mathrm{dz}}=\mathrm{k}_{\mathrm{ox}}\left[\mathrm{HSO}_{3}{ }^{-}\right]
$$

where $k_{o x}$ is the rate constant for bisulfitc oxidation.

The employed terminal velocity was given by the experiments of Gunn and Kinzer, ${ }^{29}$ and the mass-transfer coefficient was obtained from the Frössling correlation.

\subsubsection{Model predictions}

The washout model of Hill and Adamowicz was initially used to test equilibrium assumptions and later extended to examine the influence of 
oxidation, both for single drop sizes and for the full spectrum of a model drop-size distribution given by, Best. ${ }^{30}$ Moreover, the model predicts the half-11ves for $\mathrm{SO}_{2}$ removal from the model atmosphere. Only these results using the Bests's drop-size distribution will be reviewed.

The composition of rain found in a collector at ground level includes contributions from a full spectrum of drop sizes. Thus, the mixed average composition at ground level is equal to the flux of the species of interest for a given drop size summed over all drop sizes and divided by the rainfall rate.

Hill and Adamowicz have used this method to predict the raindrop concentration as a function of fall distances for two cases; these are described in Table 7, and the results obtained are shown in Figs. 8 and 9. The results are, as expected, intermediate to those for the large and small drops. From Figs. 8 and 9, the model predicts that, in the absence of bisulfite oxidation and with an acidic background $\mathrm{pH}(\mathrm{pH}=$ 4), the composition of rain reaches equilibrium with $\mathrm{SO}_{2}$ in the atmosphere after falling 100 to $200 \mathrm{~m}$ through a well-mixed pollutant layer $1 \mathrm{~km}$ deep. In contrast, no equilibrium is reached within a fall distance of $2000 \mathrm{~m}$ for a basic background $\mathrm{pH}\left(\mathrm{pH}_{\mathrm{O}}=10\right)$. Introduction of bisulfite oxidation led to an enhanced $\mathrm{SO}_{2}$ uptake at $\mathrm{pH}_{0}=4$ and a diminished uptake at $\mathrm{pH}_{\mathrm{o}}=10$.

Table 7. Input parameters used in model calculations

\section{Common parameters}

Ambient gas-phase $\mathrm{SO}_{2}$ concentration, $\mathrm{ppb}$ Ambient air temperature, $\mathrm{K}$ Mixing layer height, $\mathrm{km}$ Rainfall rate, $\mathrm{mm} \mathrm{hr}^{-1}$ Raindrop radius range, $\mathrm{mm}$ oxidation rate, $\mathrm{sec}^{-1}$

$$
\begin{aligned}
& \mathrm{X}_{\mathrm{SO}_{2}}=10 \\
& \mathrm{~T}=298 \\
& \mathrm{~h}=1 \\
& \mathrm{P}=1 \\
& \mathrm{R}=0 \text { to } 1.5 \\
& \mathrm{k}_{\mathrm{OX}}=0 \text { or } 10^{-3}
\end{aligned}
$$

\section{Specific parameters}

Initial $\mathrm{pH}$ value in raindrops $\mathrm{pH}_{\mathrm{o}}=4$ (Fig. 8) $\mathrm{pH}_{\mathrm{o}}=10$ (Fig. 9) 

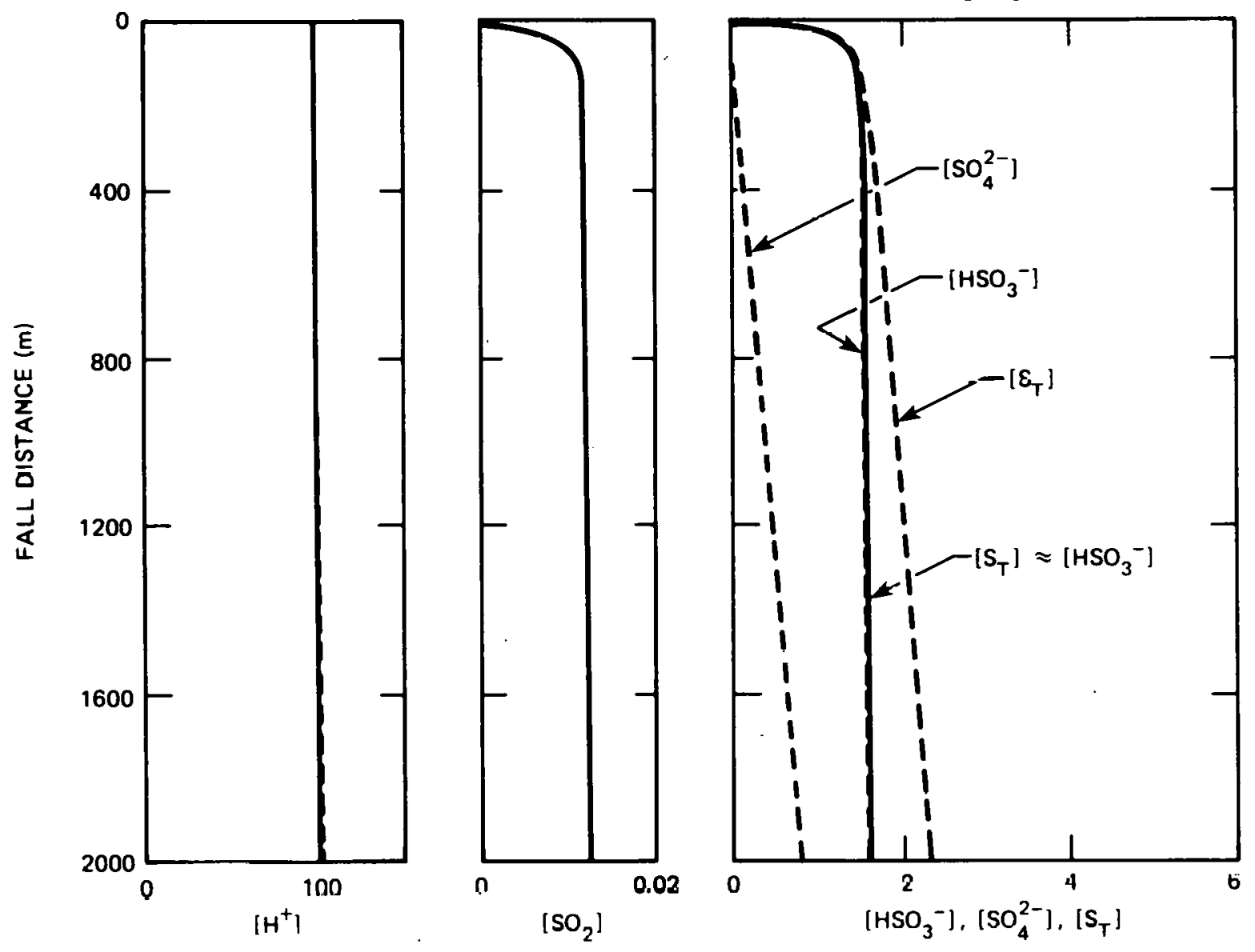

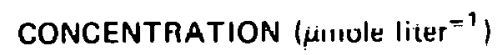

F1g. 8. Mixed average concentration transient at a rainfall rate of $1 \mathrm{~mm} \mathrm{hr}{ }^{-1}$ for the Best drop-size distribution. $\chi_{\mathrm{SO}_{2}}=10 \mathrm{ppb}, \mathrm{pH}_{\mathrm{o}}=$ 4, T $=298 \mathrm{~K}$. Source: F. B. Hill and R. F. Adamowicz, Fig. 7., p. 923 in "A Model for Rain Composition and the Washout of Sulfur Diuxlde," Atmos. Environ. 11 (1977).

\subsubsection{Discussion of the model}

The Hill and Adamowicz model is not verified by any field data. The model introduced a number of assumptions. Three of them - well-mixed drops, two-layer atmosphere, and 1iquid-phase oxidation - are disçussed.

Using Llie well=mixed drop assumption, Hill and Adamowicz assumed that diffusion or mixing within the drops is so rapid that no concentration gradients develop. With this assumption, the present model will place an upper limit on the rate of $\mathrm{SO}_{2}$ uptake. 

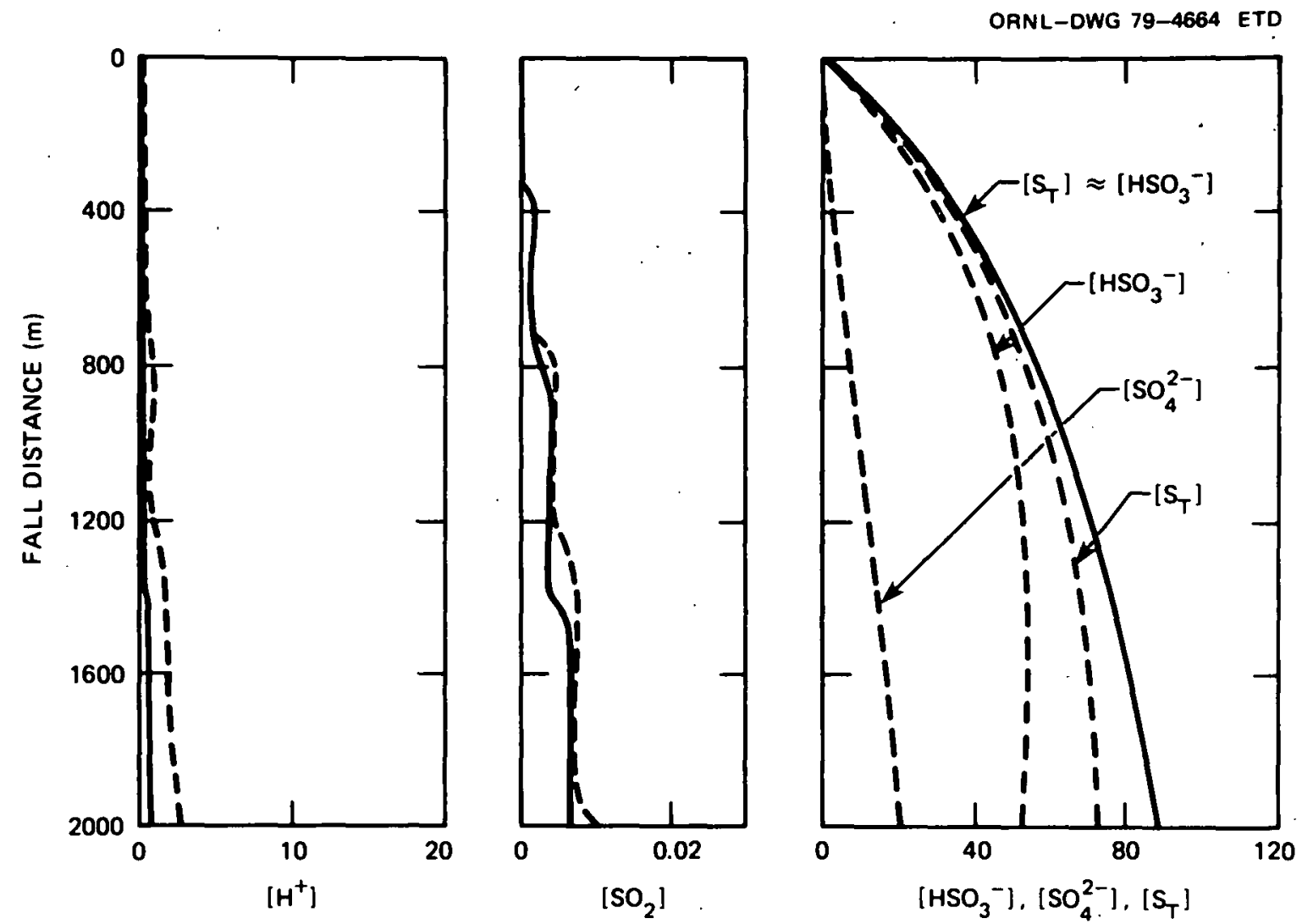

CONCENTRATION ( $\mu$ mole liter $^{-1}$ )

Fig. 9. Mixed average concentration transients at a rainfall rate of $1 \mathrm{~mm} \mathrm{hr}{ }^{-1}$ for the Best drop-size distribution. $x_{\mathrm{SO}_{2}}=10 \mathrm{ppb}, \mathrm{pH}_{\mathrm{o}}=$ $10, T=298 \mathrm{~K}$. Source: F. B. Hill and R. F. Adamowicz, Fig. 8, p. 923 in "A Model for Rain Composition and the Washout of Sulfur Dioxide," Atmos. Environ. 11 (1977).

On the two-layered model atmosphere (1.e., clean air lying over polluted air), the model will predict a uniform rainwater concentration at ground level.

W1th the liquid=phase oxidation, the model assumed that sulfate ion production is proportional to that of bisulfite ion concentration. Because of limited theoretical or experimental information on the oxidation mechanism, a full evaluation of this particular assumption is impossible. Further research on the oxidation mechanism - a controlling factor for sulfate production - is recommended. 
Finally, the specific purpose of Hill and Adamowicz's model was to predict washout of a single gas (sulfur compound in this case) in the rainwater; however, with modifications, the model can be generalized to predict the washout for multiple reactive gases, such as a system composed of sulfur dioxide, carbon dioxide, ammonia, and rainwater.

\subsection{Model by Garland - 1978}

\subsubsection{Introduction}

Garland's more1, 31 like that of Dana et al., is a combined physical and chemical model but is much simplified. It assumed a two-layered atmosphere for gas-phase $\mathrm{SO}_{2}$ concentration and a well-mixed model for ; 11quid-phase $\mathrm{SO}_{2}$ transport. Further, the model introduced an effective llenry's cunstant to account for dissociated $\mathrm{SO}_{2}$ that dissolved into wellmixed raindrops. W1th these assumptions, the concentration of $\mathrm{SO}_{2}$ in falling raindrops as a function of helght can be expressed analytically in a closed form that is distinct from those models involving elaborate computer programs.

\subsubsection{Model description}

In his model, Garland assumed that $\mathrm{SO}_{2}$ is the only pollutant component in raindrops and that raindrops are well-mixed as a result of rapid convection within drops.

For this single species system, according to Garland, sulfurous acld 1 s formed immediately after $\mathrm{SO}_{2}$ absorption. On dissolution, bisulfite and sulfite ions are formed:

$$
\mathrm{H}_{2} \mathrm{SO}_{3} \stackrel{\mathrm{K}_{1}}{\leftrightharpoons} \mathrm{HSO}_{3}^{-}+\mathrm{H}^{+}
$$

and

$$
\mathrm{HSO}_{3}{ }^{-} \stackrel{\mathrm{K}_{2}}{\leftrightharpoons} \mathrm{SO}_{3} 2^{-}+\mathrm{H}^{+} \text {, }
$$


with

$$
\mathrm{K}_{1}=\frac{\left[\mathrm{HSO}_{3}^{-}\right]\left[\mathrm{H}^{+}\right]}{\left[\left(\mathrm{SO}_{2}\right)_{\mathrm{aq}}\right]}
$$

and

$$
\mathrm{K}_{2}=\frac{\left[\mathrm{SO}_{3}{ }^{-}\right]\left[\mathrm{H}^{+}\right]}{\left[\mathrm{HSO}_{3}^{-}\right]} .
$$

By assuming uniformity of concentration within the drop and $\left[\mathrm{SO}_{3}{ }^{2-}\right]$ $\ll\left[\mathrm{HSO}_{3}{ }^{-}\right]$, Garland introduced an effective solubility:

$$
H_{\text {eff }}=H\left[1+\left(\frac{\mathrm{K}_{1} M}{\mathrm{H}_{\chi}}\right)^{1 / 2}\right] \text {, }
$$

where $\mathrm{H}$ is the ratio of dissolved undissociated $\mathrm{SO}_{2}$ to the concentration of $\mathrm{SO}_{2}$ in alr at equilibrium, and $\mathrm{M}$ is the molecular weight of $\mathrm{SO}_{2}$.

Following almost the same approach as for the model of well-mixed drops derived by Hales, ${ }^{25}$ Garland assumed that mass transport across the drops is proportional to the difference between the ambient concentration $X$ and air concentration at equilibrium with the $\mathrm{SO}_{2}$ already dissolved into the drops. It follows that

$$
\frac{d c}{d t}=\frac{3 S h D}{2 a^{2}}\left(x-\frac{c}{H_{\text {eff }}}\right) \text {, }
$$

where

$$
\begin{aligned}
\mathrm{a} & =\text { drop radius, } \\
\mathrm{c} & =\mathrm{SO}_{2} \text { concentration in raindrops, } \\
\mathrm{D} & =\mathrm{d} \text { fffusion coefficient of } \mathrm{SO}_{2} \text { in air, } \\
\mathrm{t} & =\mathrm{t} \text { imc, } \\
\mathrm{Sh} & =\text { Sherwood number. }
\end{aligned}
$$


The solution is

$$
c=\left(\mathrm{HK}_{1} \mathrm{MX}\right)^{1 / 2}\left[\left(1-\mathrm{e}^{-2 \lambda t}\right) /\left(1+\mathrm{e}^{-2 \lambda t}\right)\right],
$$

with

$$
\lambda=\frac{3 \operatorname{Sh} D}{2 \mathrm{a}^{2}}\left(\frac{\mathrm{X}}{\mathrm{HK}_{1} \mathrm{M}}\right)^{1 / 2} \text {. }
$$

\subsubsection{Model predictions}

Using the closed-form solution [Eq. (46)] and the input parametero listed in Table 8 , Garland derived the model predictions shown in Fig. 10. The calculated $\mathrm{SO}_{2}$ concentration in varlous sizes of raindrops is plotted as a function of the fall distances for two values of ambient $\mathrm{SO}_{2}$ concentration. In general, the concentration of $\mathrm{SO}_{2}$ in raindrops increases as fall distances increase. unt 11 the equilibrium state is reached. At a given ambient $\mathrm{SO}_{2}$ concentration, the curves are displaced to the right as droplets increase in oize.

Table 8. Input parameters used for model prediction

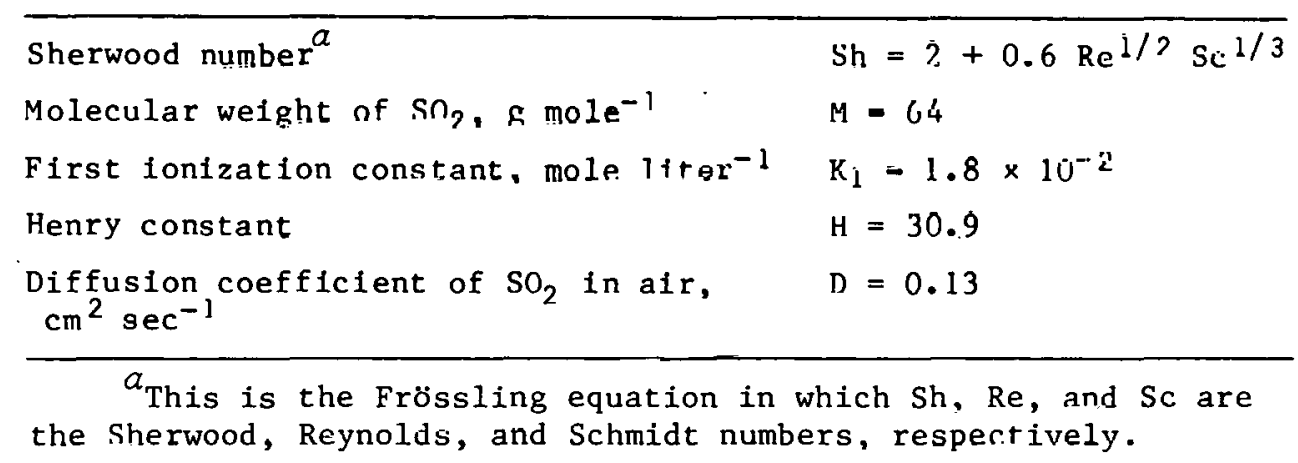

\subsubsection{Discussion of the mode1}

This simplified combined physical and chemical model provided an elegant exact solution but is not verified by field data. The closed- 


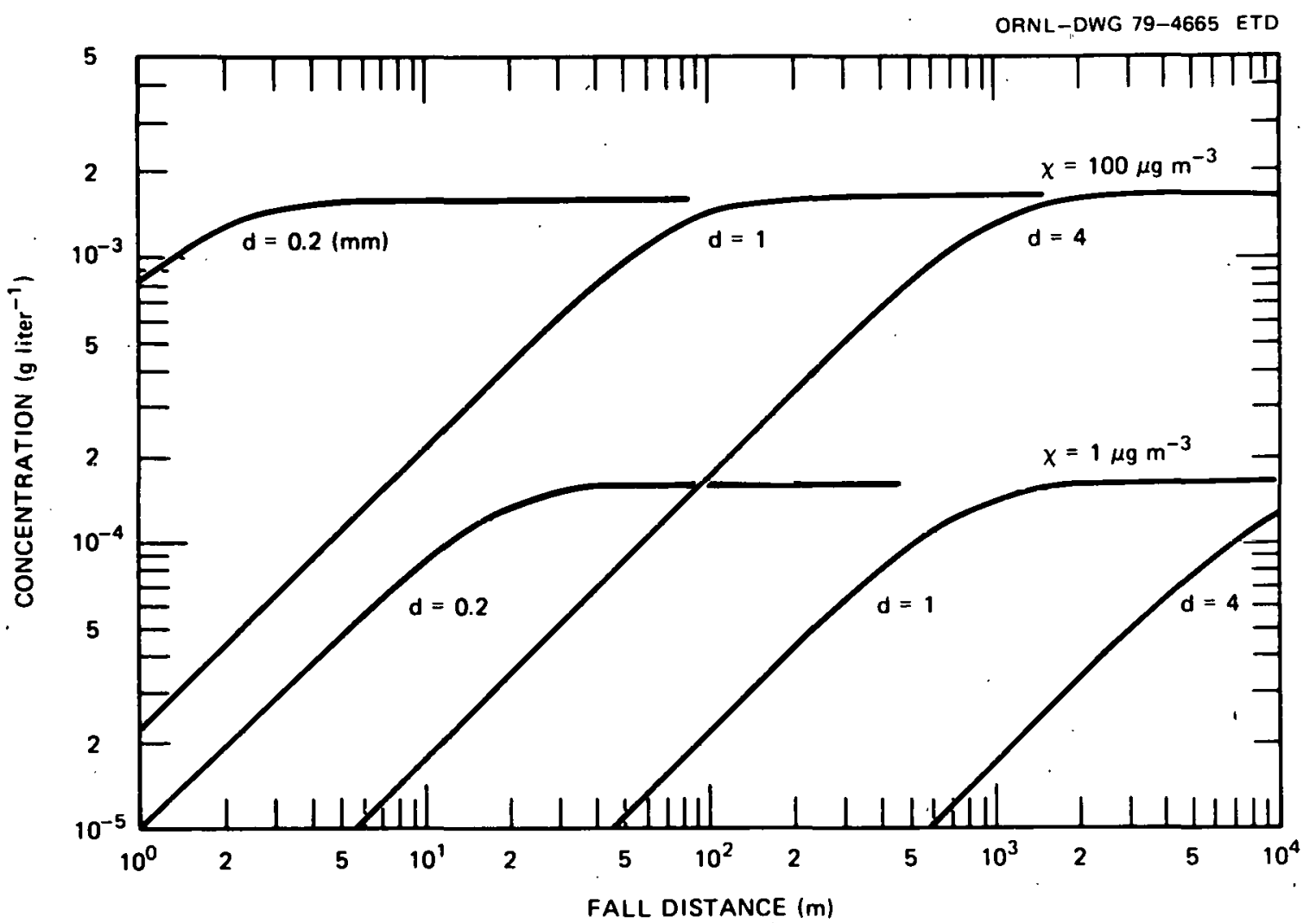

Fig. 10. Concentration of dissolved $\mathrm{SO}_{2}$ in raindrops as a function of drop diameter, fall distance, and ambient air $\mathrm{SO}_{2}$ concentration. Source: J. A. Garland, Fig. 1, p. 356 in "Dry and Wet Removal of Sulfur from the Atmosphere," Atmos. Environ. 12 (1978).

form solution is made possible by a two-layered atmosphere, along with two basic assumptions dealing with the chemical equilibrium and the mixing within drops.

For the simple $\mathrm{SO}_{2}$-liquid $\mathrm{H}_{2} \mathrm{O}$ system, Garland ignored the second dissociation [see Eq. (43)]. This is well justified because the second equilibrium constant (about $10^{-8}$ mole 11 ter $^{-1}$ ) is much smaller than that of the first equilibrium constant (about $1.8 \times 10^{-2}$ mole liter ${ }^{-1}$ ). Furthermore, Garland assumed that the concentration of $\left[\mathrm{HSO}_{3}{ }^{-}\right.$], is comparable to that of $\left[\mathrm{H}^{+}\right]$. This is true if $\mathrm{SO}_{2}$ is the only component present in the raindrops and if there are no contributors of $\left[\mathrm{H}^{+}\right]$other than $\mathrm{H}_{2} \mathrm{SO}_{3}$. With these assumptions, Garland introduced an effective solubility. The general agreement is that a thorough understanding of solubility is a 
prerequistte for any quantitative evaluation of absorption behavior. Unfortunately, experimental data on the solubility of trace concentration of $\mathrm{SO}_{2}$ in ralnwater are sparse. In addition, strong dependence of solubility on initial $\mathrm{pH}$ value is not included in the model.

For the assumption on the well-mixed drops, Garland argued that, even for a larger drop ( $1 \mathrm{~mm}$ in diam), the mixing time $\left(\sim 10^{-2} \mathrm{sec}\right.$ ) is very short compared with the time taken by the drop falling to the ground. This might be reasonable in the absence of chemical reactions, as the model assumed. Chemical reaction in the liquid phase may complicate the mixing time scale estimate considerably. Furthermore, the problem will be compounded if several reactions occur simultaneously, as the "real" raindrops suggested. 
4. MODEL EVALUATION

The major characteristics of the five $\mathrm{SO}_{2}$ washout models reviewed are summarized chronologically in Table 9. These models are being classified into three categories, depending on the assumptions involved in the models: (1) chemical, (2) physical, and (3) combined physical and chemical. For the definition of these terms, the reader is referred to the Introduction of Chapter 3.

Compared in column 3 of Table 9 is the assumption on $\mathrm{SO}_{2}$ dispersion. W1th the exception of the Scott and Hobbs model, which deals with the atmosphere in the absence of plumes, two of the models use the Gaussian plume model, and the other two employ a two-layered model. Although a two-layered model simplifies the mathematics (on occasion, an analytical solution is possible), this model ignores the effective plume dilution and may considerably affect the subsequently estimated wet deposition. Conversely, the models which use the Gaussian plume model treat the plume dilution properly but only over relatively flat terrain. Whether the Gaussian plume model can be appropriately applied to elevated smokeplumes over rough terrain was never satisfactorily proven and will require further experimental verification. As an interim guldeline for rough terrain, the $\mathrm{K}$-theory for $\mathrm{SO}_{2}$ dispersion is highly recommended.

Chemical species studied in raindrops are compared in column 4. Most of the models are considered only for a single species - $\mathrm{SO}_{2}$ gas. Cliemical analyoce show that sulfate and nitrate are the main ingredients of acidity, and the low $\mathrm{pH}$ values are attributed to $\mathrm{SO}_{2}$ and $\mathrm{NO}_{\mathrm{x}}$, produced by the combustion of coal. These are partially neutralized by species such as $\mathrm{NH}_{3}$ and basic metal oxides on particles. Consequently, any model that intends to accurately predict wetfall chemistry should include all major species that are present in ralndrujs.

In the last column, the sulfur oxidation mechanism - a control factor for sulfate production in raindrops - is being included for comparison. Most of the models assumed an uncatalyzed liquid-phase oxidation of $\mathrm{SO}_{2}$ by oxygen. The sulfate production rate is assumed to be proportional to the sulfite and bisulfite ion concentrations by the models of Scott and Hobbs and Hill and Adamowicz, respectively. Generally, 
Table 9. Sumary of model characteristics for wet-deposition-rate predication ${ }^{a}$

\begin{tabular}{|c|c|c|c|c|}
\hline Investigator & Model & $\mathrm{SO}_{2}$ disperstor & Chemfcal spectes studied & $\begin{array}{l}\text { Sulfur oxidation } \\
\text { mechanism }\end{array}$ \\
\hline $\begin{array}{l}\text { Scott and Habbs } \\
(1967)\end{array}$ & Chenical & No plune & $\begin{array}{l}\text { Single spezies } \\
\left(\mathrm{SO}_{4}{ }^{2-} \text { with } \mathrm{NH}_{3} \text { as } 3 \text { ca:alyst) }\right.\end{array}$ & $\begin{array}{l}\text { Liquid-phase oxidation } \\
\frac{\mathrm{d}\left[\mathrm{SO}_{4}{ }^{2-}\right]}{\mathrm{dt}}=\mathrm{K}_{1}\left[\mathrm{SO}_{3}{ }^{2-}\right]^{b}\end{array}$ \\
\hline $\begin{array}{l}\text { Hales et al. } \\
(1973)\end{array}$ & Physical & Gaussian plume & $\begin{array}{l}\text { Single species } \\
\text { (dissolved } \mathrm{SO}_{2} \text { only) }\end{array}$ & None \\
\hline $\begin{array}{l}\text { Dana et al. } \\
(1976)\end{array}$ & $\begin{array}{l}\text { Combined physical } \\
\text { ani chemical }\end{array}$ & Gaussian Jlime & $\begin{array}{l}\text { Mult1ple spectes } \\
\left(\mathrm{SO}_{2}, \mathrm{SO}_{4}-\frac{\mathrm{H}^{+}}{} \text {, and } \mathrm{NH}_{4}^{+} \text {with } \mathrm{NH}_{3}\right)\end{array}$ & Same as Scott and Hobbs \\
\hline $\begin{array}{l}\text { H111 and Adanowicz } \\
\text { (1977) }\end{array}$ & $\begin{array}{l}\text { Comtined physical } \\
\text { and chemical }\end{array}$ & $\begin{array}{l}\text { Two-layered atmosphere } \\
\text { (clean } a=r \text { above pol- } \\
\text { luted } \mathbf{1} \mathbf{r} \text { ) }\end{array}$ & $\begin{array}{l}\text { Mult1ple species } \\
\left(\mathrm{SO}_{2}, \mathrm{SO}_{4}-\text {, and } \mathrm{H}^{+} \text {wittout } \mathrm{NH}_{3}\right)\end{array}$ & $\begin{array}{l}\text { Liquid-phase oxidation } \\
\frac{\mathrm{d}\left[\mathrm{SO}_{4}{ }^{2-}\right]}{d \tau}=\mathrm{K}_{2}\left[\mathrm{HSO}_{3}{ }^{-}\right]^{c}\end{array}$ \\
\hline Garland (1978) & $\begin{array}{l}\text { Simplified physical } \\
\text { and chemical }\end{array}$ & Two-lay?red atmosphere & $\begin{array}{l}\text { Single spectes } \\
\text { (dissolved and disscciated } \mathrm{SO}_{2} \text { ) }\end{array}$ & None \\
\hline
\end{tabular}

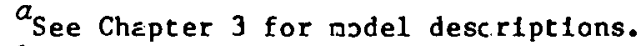

${ }^{b} \mathrm{SO}_{3}{ }^{2-}$ and $\mathrm{SO}_{4}{ }^{2-}$ are sulfite and sulfate lon concentratica in raindrops, respectively; $\mathrm{K}_{1}$ denotes oxidation rate constant $\left(\mathrm{K}_{1}=1.67 \times 10^{-3} \mathrm{sec}^{-1}\right.$ at $\left.25^{\circ} \mathrm{C}\right)$. $\left.25^{\circ} \mathrm{C}\right)$.

${ }^{c}$ [HSO $\left._{3}^{-}\right]$represents bisulfite ion concentration In raindrops; $\mathrm{K}_{2}$ denotes another oxidation rate constant $\left(\mathrm{K}_{2}=10^{-3}\right.$ sec ${ }^{-1}$ at
} 
this proportionality constant - the pseudo first-order rate coefficient in the reaction varies with the $\mathrm{pH}$ of solution. However, fixed values were assumed in both models. Such $\mathrm{pH}$ dependence has been discussed and compared for various studies by Hegg and Hobbs 32 and Bellke and Gravenhorst. 33

Apart from the difference in proportionality among models, the species being oxidized are also different. The combined effect is best demonstrated by plotting sulfate production rate vs $\mathrm{pH}$ of the solution. When this is done in a semilogarithmic scale (Fig. 11), a surprising simple linear relationship is revealed with slopes of $1,1.5$, and 2 for the Hill and Adamowicz, Fuller and $\mathrm{Crist}^{34}$ (as modified by McKay ${ }^{35}$ ), * and Scott and Hobbs models, respectively. For comparison purposes, the experimental results have been extrapolated over a range of $\mathrm{pH}$ values using the derived rate law shown in Table 9, along with the one used by Fuller and Crist, as modified by McKay:

$$
\frac{\mathrm{d}\left[\mathrm{SO}_{4}{ }^{2-}\right]}{\mathrm{dt}}=\left(\mathrm{K}_{3}+\mathrm{K}_{4}\left[\mathrm{H}^{+}\right]^{\mathrm{I} / 2}\right)\left[\mathrm{SO}_{3}{ }^{2-}\right]
$$

with

$$
\left[\mathrm{SO}_{3}{ }^{2-}\right]=\mathrm{K}_{1 \mathrm{~s}} \mathrm{~K}_{2 \mathrm{~s}} \mathrm{~K} h \mathrm{Ps}_{\left[\mathrm{H}^{+}\right]^{2}}^{\mathrm{P}},
$$

where $K_{1 s}, K_{2 s}, K_{h s}$ are equilibrium constants for the first and second dissoclation ionization and Henry's constant for sulfur dioxide; $K_{3}$ and $\mathrm{K}_{4}$ are rate contstants; $\mathrm{P}_{\mathrm{SO}_{2}}$ is the partial pressure of $\mathrm{SO}_{2}$ in the atmosphere, and $\left[\mathrm{H}^{+}\right]$is the hydrogen ion concentration.

'These equilibrium constants and their values at $25^{\circ} \mathrm{C}$ are defined and given in Sects. 3.1.2 and 3.1.3, where the model of Scott and Hobbs is reviewed. In addition, the partial pressure of $\mathrm{SO}_{2}$ and rate constants used In calculations are: $\mathrm{P}_{\mathrm{SO}_{2}}=1.4 \times 10^{-8} \mathrm{~atm}, \mathrm{~K}_{3}=1.3 \times 10^{-2} \mathrm{sec}^{-1}$ and $\mathrm{K}_{4}=59 \mathrm{sec}^{-1} \mathrm{M}^{-1 / 2}$.

\footnotetext{
*Fuller and Crist's study was not reviewed. For purposes of
} comparison, it is being included. 


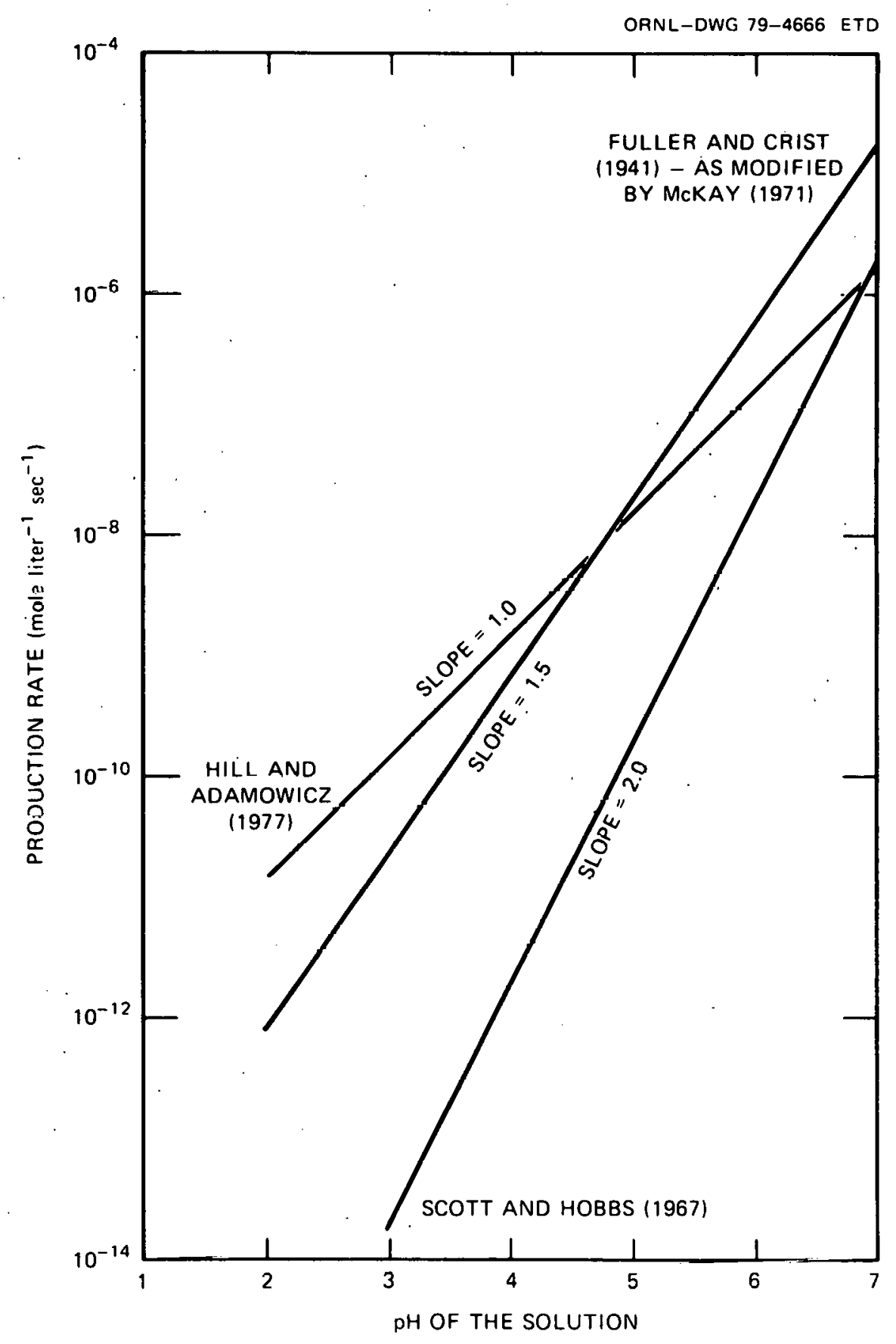

Fig. 11. Rate of sulfate production vs $\mathrm{pH}$ of the solution for the uncatalyzed liquid-phase oxidation of $\mathrm{SO}_{2}$ by oxygen. 
As shown in Fig. 11, the discrepancy in the predicted sulfate production rate increases with acidity. For the raindrops of interest, with $\mathrm{pH}$ ranging from 3 to 6 , the maximum difference in the predicted rate of sulfate production between the model of Hill and Adamowicz and the model of Scott and Hobbs is about four orders of magnitude.

None of the models reviewed thus far consider liquid-phase sulfur oxidation by ozone. As pointed out by Hegg and Hobbs, this reaction may be important in the atmosphere and cannot be ruled out entirely. Moreover, the effects of catalyzed reactions by trace metals or the mixed salts ${ }^{36}$ have not been accounted for. Recent developments regarding these questions are discussed in the proceedings of the International symposium on Sulfur in the Atmosphere and are published in Atmospheric Environment. 37

In summary, given the present state of the art, no model can claim superiortty over any other model without data verification. The Dana et a1. model, tested against Centralia data, is an exception. The predicted values for $\mathrm{SO}_{4}{ }^{2-}$ are in the same order of that of observed values, but the predicted $\mathrm{SO}_{2}$ (dissolved and disassociated) exceeds that observed by more than one order of magnitude. The discrepancy was attributed to the Inadequacy of the adopted Scott and Hobbs ammonia model for $\mathrm{SO}_{2}$ oxidation. This should be resolved by further improvement, both in model development and in field data measurements. 


\section{STUDIES OF WETFALL CHEMISTRY AROUND PLANT BOWEN}

As stated in the Introduction, the specific objective of this study is to determine the extent to which the power plant plumes affect wetfall chemistry on a local scale. The chemical species being identified as the key constituents in rainwater which will be monitored include $\mathrm{SO}_{2}, \mathrm{SO}_{4}{ }^{2-}$, $\mathrm{pH}$, conductivity, and trace metals. To study this problem, the feasibility of expanding the METER-ORNL research at Bowen Power Plant in northwest Georgia to include additional wetfall chemistry is evaluated using (1) results of similar studies around other pnorer planta, (2) several atmospheric washout models, (3) analysis of spatial variability in precipitation, and (4) fleld logistical considerations. With the first two considerations, which are discussed in Chapters 2 and 3 , the maximum plume washout in relation to the stack at Plant Bowen during a steady rain is estimated. Further, with the last two considerations (to be discussed in this chapter), an optimal wetfall chemistry network is proposed by considering the size of sampling network, the collector density, the operational requirements, and the experimental design.

Sampling of precipitation on a rainfall-event basis maximizes detection of plume-scavenging effects and will be used to define the magnitude of the contribution of precipitation to sulfur dioxide, hydrogen ion, and trace metals deposition. Samples will be collected from frontal-type precipitation events, which provided the most favorable conditions for sampling because they generally provide spatially uniform rainfall over a long duration. Moreover, target and control areas for these rain episodes are relatively casy to identify with the knowledge of surface and upper-air winds. Prevailing surface winds in north Georgia are from the northwest, while the predominant storm tracks are from southwest to

northeast. ${ }^{38}$ Under those circumstances, potential wet deposition of plume-derived constituents will be at a maximum in the general northeastern area from Plant Bowen. The ease of identification of the control and target areas under relatively steady wind conditions will substantially enhance the data interpretation. 


\subsection{Estimation of Sulfur Washout}

Concentrations of $\mathrm{SO}_{2}$ and $\mathrm{pH}$ in raindrops underneath plumes are estimated with two assumptions: the Gaussian plume dispersion and an equilibrium state between raindrops and the immediate surrounding $\mathrm{SO}_{2}$ gas concentration. 19 Given a warm frontal-type precipitation in winter, the worst case (zero plume rise and $100 \%$ frequency with which the wind blows toward a $22.5^{\circ}$ sector) is to be considered. A set of input parameters relevant to Plant Bowen is given in Table 10, and the predicted values are shown in Table 11. Also included are the dependence of $\mathrm{SO}_{2}$ and $\mathrm{H}^{+}$ washout on the intial $\mathrm{pH}$ values. The maximum predicted washout flux at ground level for various types of rainfall is shown in Table 12. If rainfall occurs during $20 \%$ of the year and one-third of this is of the light shower type in northwest Georgia, the annual deposition rate is calculated to be about $2.24 \mathrm{~g} \mathrm{~m}^{-2}$ year $^{-1}$, which is within the range of the representative annual average wet deposition in heavily industrialized areas in North America $\left(0.1\right.$ to $3 \mathrm{~g} \mathrm{~m}^{-2}$ year $\left.{ }^{-1}\right) .^{37}$

Table 10. Input parameters for washout flux calculations at Plant Bowen

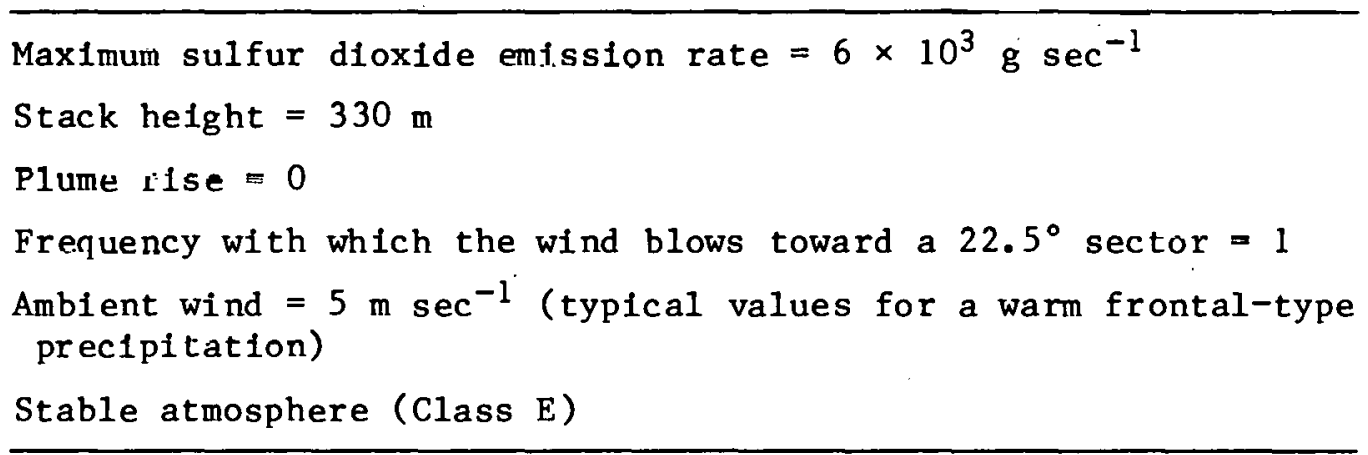

\subsection{Estimation of Trace Metals Washout}

Many heavy metals or thefr compounds are toxic to humans, other animals, and plants. In this study, estimation of the wet deposition of trace elements will be confined to the elements of mercury, copper, and lead discharged from the smokestacks of Plant Bowen. The reason for this 
Table 11. Washout $\mathrm{SO}_{2}$ and $\mathrm{H}^{+}$concentration for a stable atmosphere (Class $\mathrm{E})^{\alpha}$

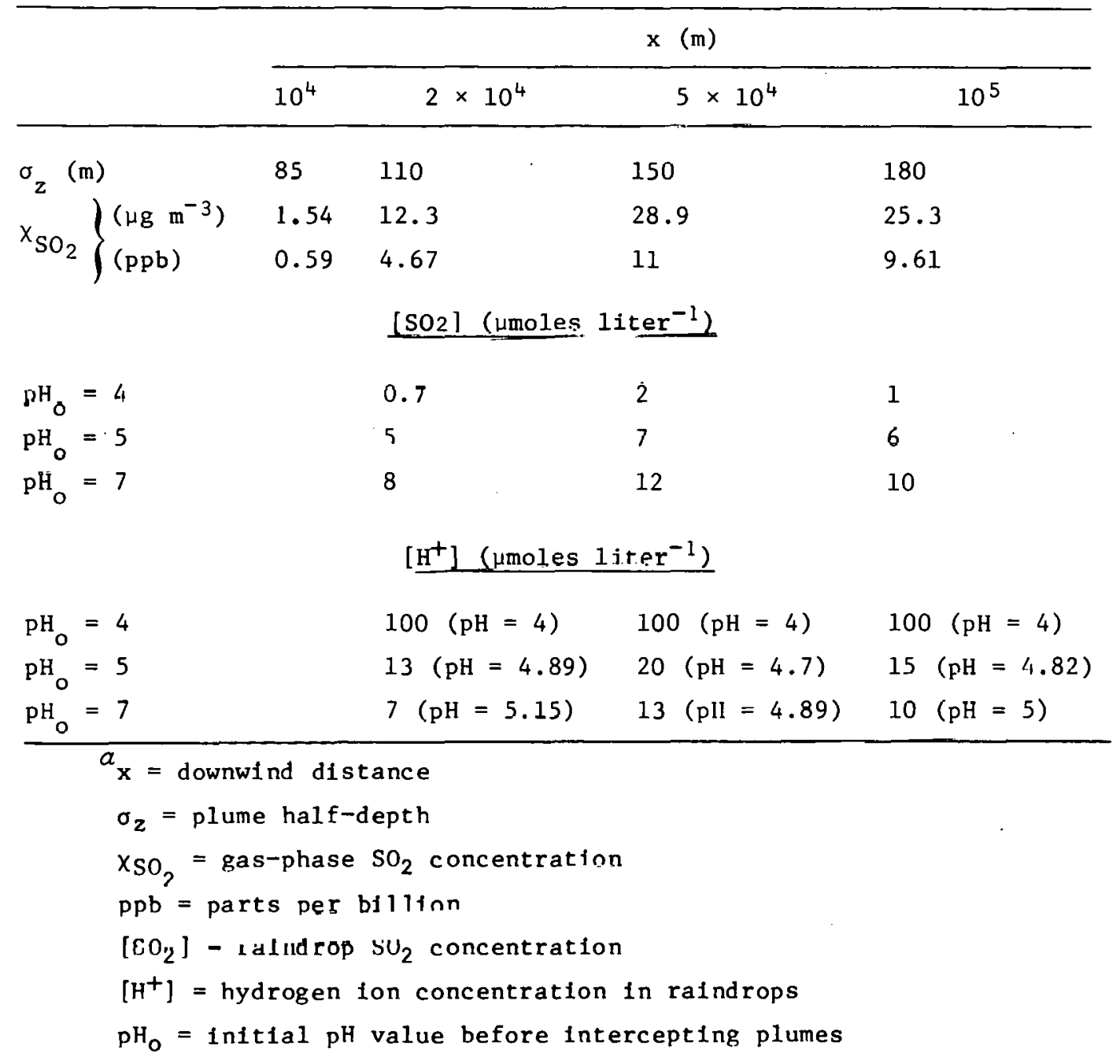

Table 12. Wet deposition rates at the maximum ground-level $\mathrm{SO}_{2}$ concentration location ( $\left.=5 \times 10^{4} \mathrm{~m}\right)$ for neutral rain $\left(\mathrm{pH}_{\mathrm{O}}=7\right)$

\begin{tabular}{|c|c|c|c|c|}
\hline \multirow[t]{2}{*}{ Rainfall type } & \multirow{2}{*}{$\begin{array}{l}\text { Medium } \\
\text { drop size } \\
\quad(\mu \mathrm{m})\end{array}$} & \multirow[t]{2}{*}{ 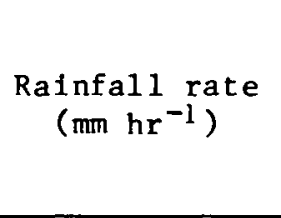 } & \multicolumn{2}{|c|}{$\begin{array}{l}\text { Wet deposition } \\
\text { rate } \\
\left(\mu \text { moles } \mathrm{m}^{-2} \mathrm{hr}^{-1}\right)\end{array}$} \\
\hline & & & {$\left[\mathrm{SO}_{2}\right]$} & {$\left[\mathrm{H}^{+}\right]$} \\
\hline Drizzle & 300 & 0.2 & 2.4 & 2.6 \\
\hline Light shower & 850 & 5.0 & 60.0 & 65.0 \\
\hline Heavy shower & 1200 & 20.0 & 240.0 & 260.0 \\
\hline
\end{tabular}


particular choice is that mercury is almost totally emitted as vapor, but copper and lead are discharged as particulates. The methods of calculation, however, can be applied to other trace metals as well.

About $90 \%$ of the coal burned at Plant Bowen is from the western Kentucky mines. Analysis of the coal composites recelved on August 15, 1978, by Southern Company Services, Inc., ${ }^{39}$ gave the following results: moisture, 4.35\%; ash, 12.65\%; sulfur, $1.3 \%$; Btu/1b (as fired), 12,400.

The trace element content in coal can vary greatly between mines and even within a single coal bed. Furthermore, composition of combustion products from a single power plant can also vary, depending on operating conditions. Because trace metal concentration in coal burned at Plant Bowen is not given by Southern Company Services, Inc., the source strength of these trace metals emitted from Plant Bowen can only be estimated approximately using literature values for coal composition. The washout problem is further compounded by such factors as amount of rain, wind speed and direction, washout efficiency, transformation, and transport. Consequently, the following calculations should be viewed cautiously and verified by field measurements.

Mercury. Approximately $90 \%$ of the mercury in the coal that is fired in the boiler is emitted to the atmosphere as vapor in the stack gas, according to Billings et al. 40 Thus, in the following calculation, mercury is assumed to be discharged $100 \%$ in the vapor phase and dispersed as a Gaussian plume. The maximum ground-level air mercury concentration is $0.37 \mathrm{ng} \mathrm{m}^{-3} 50 \mathrm{~km}$ downwlind of the stack for (1) an emission rate of $7.64 \times 10^{-2} \mathrm{~g} \mathrm{sec}^{-1}$, (2) mercury concentration in coal of $0.19 \mathrm{ppm}$ by weight, 41 and (3) the input data listed in Table 10.

In the present study, mercury washout is calculated by two approaches: method of equilibrium solubility and method of washout factor. The method of equilibrium solubility is the same as that of $\mathrm{SO}_{2}$ washout. Detailed processes of the mass transport between mercury vapor and raindrops during their fall from plumes to the ground is not considered important. Instead, the amount of dissolved mercury vapor is determined when an equilibrium state is reached between mercury vapor and raindrops at ground level. 
Sanemasa ${ }^{42}$ reported equilibrium solubility of elemental mercury vapor in pure water and found that the aqueous solubility of mercury vapor obeys Henry's law at each solution temperature ranging from 5 to $60^{\circ} \mathrm{C}$. However, his data did not extend into the extreme low mercury vapor pressure (e.g., air concentration of mercury $=20 \mathrm{ng} \mathrm{m}^{-3}$ or less), such as those present. in the atmosphere. 43

For information on mercury vapor pressure and saturated mercury concentration in air as a function of temperature, the reader is referred to two sources: Hondbook of Chemistry and. Physics ${ }^{44}$ and a report on Mercury in the Environment. 45

Assuming that Henry's law can be applied to extreme low mcrcury cülcencrations ( $U .3 / \mathrm{ng} \mathrm{m}^{=3}$ ) in air, the corresponding equilibrium mercury concentration in pure water is calculated to be about $1.2 \times 10^{-6} \mathrm{\mu g}$ liter ${ }^{-1}$. The calculated value is unrealistically low. Perhaps this is partly caused by the linear extrapolation of Henry's law to the extreme low-concentration region and partly by the use of pure water as a solvent. In reality, the amount of dissolved mercury might be different when water, such as rainwater, is not pure. 46

In view of the uncertainties involved in the concept of equilibrium solubility, the method using washout factor is applied. The washnut factor is defined as the ratio of concentration in rain to the concentration in air. By this method, concentration of mercury in rainwater is found to be $\sim 0.34 \mathrm{\mu g}$ liter ${ }^{-1}$, with a washout factor of $10^{3}$, a value derived from Wraymires' results by Peirson et al. ${ }^{47}$ Although this estimated concentration in rainwater ( $0.34 \mu \mathrm{g}$ liter $\left.{ }^{-1}\right)$ agrees surprisingly well with those field data reported by Andren and Lindberg, ${ }^{48}$ confirmatory studies on the mercury washout by the field experiment around Plant Bowen would he valuable.

Copper. Copper released by coal combustion is discharged to the atmosphere mainly in the particulate form. With an efficient electrostatic precipitator on the flue, the particle size of copper released to the atmosphere ranges from 1 to $15 \mu \mathrm{m} .49$ The terminal speed of a $15-\mu \mathrm{m}$ particle is about $5 \mathrm{~cm} \mathrm{sec}^{-1}$. As Van der Hoven 50 recommends, for terminal speeds less than $1 \mathrm{~m} \mathrm{sec}^{-1}$, the Gaussian plume model or diffusion equation can be used to calculate the diffusion and subsequent deposition 
of the particulate; however, the particulate plume descends at speed $v_{d}$, the terminal speed, relative to, the gaseous plume.

By use of the Gaussian plume model for copper dispersion and the method of washout factor, the maximum ground-level copper concentration in afr and ralnwater is found to be $68.3 \mathrm{ng} \mathrm{m}^{-3}$ and $46.6 \mu \mathrm{g} 1$ iter $^{-1}$ at a downwind distance of $33 \mathrm{~km}$, with the following input data relevant to Plant Bowen: emission rate, $0.72 \mathrm{~g} \mathrm{sec}^{-1}$; copper concentration in coal, $18 \mathrm{ppm}{ }^{41}$ emission factor, $10 \%$; washout factor, $880 ; 47$ terminal speed, $5 \mathrm{~cm} \mathrm{sec}^{-1}$ (assume the maximum particle size for the worst-case estimate); and input data listed in Table 10.

Lead. Like copper, lead released by coal combustion is emitted to the atmosphere (mainly in particulate form) and assumes a similar particle size spectrum. 47 Thus, the method used for copper calculations is applied. The maximum ground-level lead concentration in a1r and

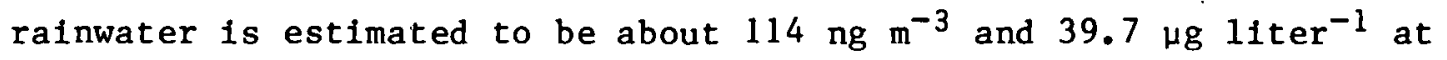
a downwind distance $33 \mathrm{~km}$ from the stack, with the following input of Plant Bowen: emission rate, $1.2 \mathrm{~g} \mathrm{sec}^{-1}$; lead concentration in coal, $30 \mathrm{ppm} ;{ }^{41}$ emission factor, $10 \%$; washout factor, $450 ;{ }^{47}$ terminal speed, 5 cm $\mathrm{sec}^{-1}$; and input data given in Table 10 .

The maximum ground-level washout flux of mercury, copper, and lead for various types of rainfall is shown in Table 13. Note that the distance of the maximum deposition location for particulates is three-fifths that of gas-phase pollutants from the stack. Also, for the drizzle, the predicted wet deposition rate between the two differs by several hundred.

Table 13. Wet deposition rates at the locations of maximum ground-level concentration for mercury $\left(X \simeq 5 \times 10^{4} \mathrm{~m}\right)$, copper, and lead $\left(X \simeq 3.3 \times 10^{4} \mathrm{~m}\right)$

\begin{tabular}{lcccc}
\hline & & \multicolumn{3}{c}{$\begin{array}{c}\text { Wet deposition rate } \\
\left(\text { Roles } \mathrm{m}^{-2} \mathrm{hr}^{-1}\right)\end{array}$} \\
\cline { 3 - 6 } & $\begin{array}{c}\text { Rainfall rate } \\
\left.(\mathrm{mm} \mathrm{hr})^{-1}\right)\end{array}$ & Mercury & Copper & Lead \\
\hline Drizzle & 0.2 & $3.38 \times 10^{-4}$ & 0.15 & 0.04 \\
Light shower & 5.0 & 0.01 & 3.67 & 0.96 \\
Heavy shower & 20.0 & 0.03 & 14.67 & 3.83 \\
\hline
\end{tabular}




\subsection{Spatial Variability in Precipitation}

If a concentration field is used as a means to detect the effects of Plant Bowen plumes in wetfall chemistry, given the same washout efficiency in control and target areas, two key elements influencing the concentration field should be considered: a steady plume and a uniform and persistent precipitation. For the plume, both plume strength (constituents) and plume position are believed to remain steady during winter frontal storms because a stable atmosphere prevails. A frontal-type rain is also preferred because it generally provides spatially uniform rainfall of long duration and constant intensity. Without these characteristics, severe random dilution or enrichment of the "underplume" samples is inevitable.

The spatial variability of four storms occurring at the METER-ORNL network were investigated to evaluate the uniformity. Results are presented in.Table 14. The values of spatial variability in rainfall volume ranged from 8 to $31 \%$. This limited comparison suggests that spatial variability decreases as the mean rainfall increases.

Table 14. Variability of precipitation fur four storms over $740 \mathrm{~km}^{2}$ at Plant Boweii

\begin{tabular}{lllcc}
\hline Storm type & Date & $\begin{array}{c}\text { Number of } \\
\text { stations }\end{array}$ & $\begin{array}{c}\text { Mean rain } \\
(1 \mathrm{n} .)\end{array}$ & $\begin{array}{c}\text { Standard } \\
\text { deviation/mean } \\
\text { (\%) }\end{array}$ \\
\hline Stationary front & Feb. 28, 1978 & 25 & 0.25 & 31 \\
Stationary front & Mar.7, 1978 & 25 & 0.25 & 29 \\
Cold front & Dec. 21, 1978 & 25 & 0.50 & 12 \\
Warm front & Jan. 23, 1979 & 25 & 0.84 & 8 \\
\hline
\end{tabular}

The spatial variability in concentration and deposition at Plant Buwen cannot be evaluated because no data are currently available. However, spatial variability in concentration and deposition has been evaluated at other networks of similar size and collector density. The work by Stout and Huff51 cited by Gatz ${ }^{52}$ indicated that, for event samples, 
the relative variability increases in the order of rainfall, concentration, and deposition.

\subsection{Methodology}

The approach to collection and analysis of wetfall around Plant Bowen as outlined in the following paragraphs is fundamentally common to all studies of wetfall chemistry, differing only in details.

Equipment

In most wetfall chemistry studies, wetfall is collected using a rainfall-activated device that automatically opens a collector (e.g., bottle-funnel or widemouth container) whenever rainfall occurs. During dry weather, the collector is sealed against the influx of dryfall. Such collectors are expensive and normally require $110 \mathrm{~V}$ ac for operation; thus, they were impractical for a preliminary network-wide investigation of wetfall chemistry around Plant Bowen.

Given sufficient manpower, accurate weather forecasts, and good 10gistical planning, a network of manually operated wetfall collectors can be used successfully to investiyate wetfall chemistry around power plants. For the Plant Bowen studies, a simple inexpensive collector was designed consisting of an 11.5-cm-diam polyethylene funnel inserted into a 1-1iter polyethylene bottle that is supported in a collar atop a pole $22 \mathrm{~m}$ above the ground. Collection of wetfall alone is achieved by manually uncovering the funnel, which is covered by a plastic bag, just prior to the onset of rainfall and recovering the funnel at the cessation of rainfall.

\section{Collector preparation}

In preparation for rainfall sampling, the polyethylene bottles, 11ds, and funncle are thornughly cleaned in the laboratory using dilute (2N) nitric acid and high-quality distilled-deionized water. Following the acid cleaning, the bottle, lids, and funnels are rinsed and soaked repeated ly in fresh distilled-deionized water until all traces of residud acid in the rinse water are absent. The bottles and funnels are then packaged in. individual plastic bags for transport to the field sites. 


\section{Collector operation}

Pursuant to the requirement of excluding dryfall from the collectors, as far as practical, installation and uncovering at field sites are delayed until just before the onset of rainfall. Of course, the exact time of onset cannot be known in advance, and, thus, reliance must be placed on forecasts from the National. Weather Service. With 5 field persons, $\sim 1-1 / 2 \mathrm{hr}$ are required to install and uncover the 50 collectors. Thus, to ensure that all collectors are open prior to the first rainfall, the first collector must be uncovered no later than 1-1/2 hr prior to the forecasted time of rainfall onset. The collectors can be uncovered car lier, but, to minimize incorporation of dryfall, it was decided that no collectors should be open longer than $3 \mathrm{hr}$ prior to the first rainfall. This is, of course, a compromise necessitated by limited manpower and the slze of the network.

At the cessation of rainfall, the collectors are covered and retrieved as rapidly as possible. Timing is considered less important on the retrieval because dryfall at the end of a storm is likely to be miniind and any that occurs is likely to be trapped on the moisture on the funnel and not incorporated into the sample. Thus, it was decided that retrieval should be complete within $6 \mathrm{hr}$ of rainfall cessation.

Rainfall does not always begin and continue without interruption. Thus, some operational definition of an "event" is necessary. For this study, a rainfall "event" is defined as beginning at the first few drops of rainfall and ending if rainfall is interrupted for more than $6 \mathrm{hr}$.

\subsection{S1te Criteria}

The wetfall chemistry collectors are sited to conform as nearly as possible with the following criteria, as suggested by the North Central Regional Project NC-141 Atmospheric Deposition. 53

1. No moving sources of pollution, such as routine air, ground, or water traffic, shall be within $100 \mathrm{~m}$ of the site.

2. No surface storage of agricultural products, fuels, or other foreign materials shall be within $100 \mathrm{~m}$ of the site. 
3. No continuous sources of pollution shall be within $50 \mathrm{~km}$ in the direction of the mean wind direction for the site and $30 \mathrm{~km}$ in all other directions.

4. Sampler shall be installed over undisturbed land, preferably grass covered, with no objects within $5 \mathrm{~m}$ of the sampler.

5. No object shall project onto the sampler with an angle greater than $30^{\circ}$ from the horizontal. Give particular attention to overhead wires.

Thus, the additional collectors should be placed along major highways for easy access but should be placed at a clearing bank at least $30 \mathrm{~m}$ from the highways to minimize contamination caused by traffic. The major concern here is the dispersion of exhaust fumes under strong surface winds.

Once the site is located, an information sheet (see the following page) covering the important points necessary to evaluate the site should be completed and returned to ORNL as soon as possible.

\subsection{Network Design}

The METER-ORNL wetfall chemistry network was designed to provide a high probability of detecting the effects of Plant Bowen on local wetfall chemistry. The optimal network design resulted from combined considerations described in the previous subsections, that is, predicted sulfur and trace metals deposition in the vicinity of Plant Bowen, an analysis of precipitation spatial variability in proposed METER-ORNL wetfall chemistry network, site selection criterion, and practical methodology for data acquisition.

To maximize the capabilities of the fleld study, the sampling network is to cover uil area of $710 \mathrm{~km}^{2}(2.89 \mathrm{sq} \mathrm{miles),} \mathrm{that} \mathrm{is,} \mathrm{the} \mathrm{inner}$ 5 hy 5 matrix measuring $27 \mathrm{~km}$ ( 17 miles) on a side (see Fig. 12). Plant Bowen is situated $4.8 \mathrm{~km}$ ( 3 miles) west of the network center because the target area for the vast majority of storms would be in the eastern half, rather than the western half, of the network.

The size of the wetfall chemistry network was limited to a scale smaller than that of the existing rain-gauge network primarily because of 
METER-ORNL WETFALL CHEMISTRY NETWORK

Information Sheet

DATE :

SITE NUMBER:

LOCATION:

COLLECTOR OPENING TIME :

COLLECTOR CLOSING TIME:

S'IACKPLIME DIRECTION (BY OBSERVATION):

COOLING TOWER PLUME DIRECTION (BY ORSF.RVATION):

GENERAL DE SCRIPTION OF COLLECTING SITES :

(1) TYPE OF ROAD GURFACE :

(2) HOW FAR FROM THE ROAD IS COLLECTOR SITED?

(m)

(3) HOW CLOSE CAN A VEHICLE APPROACH THE COLLECTOR? ___ (m)

(4) TKEE:__ MAX. HEIGHT:___ _ _ _ _ _

DISTANCE :__ (m), DIRECTION:

(5) BUILDING (TYPE): _ _ HEIGHT: _ _ _ _ _

DISTANCE :

(m), DIRECTION:

(6) OBJECT: , HEIGHT: , (UI)

DISTANCF: $\quad$ (III), DIRECTIUN:

(7) OTHER (e.g., OVERHEAD WIRES, MASTS, HILLY TERRAIN OR FLAT, etc.): 
ORNL-DWG 78-4197A

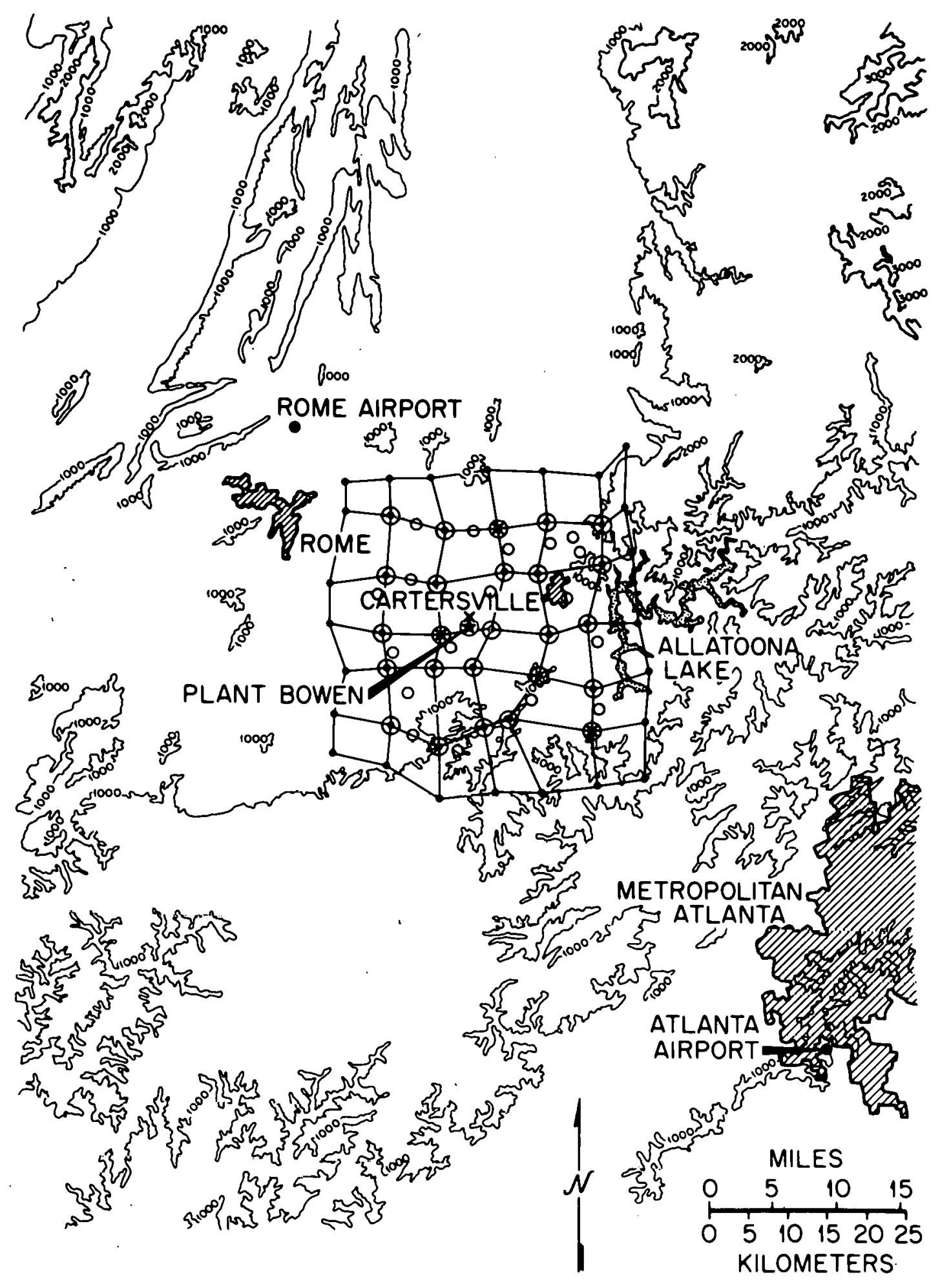

Fj.g. 12. Map showing the METER-ORNL wetfall chemistry network in relation to METER-ORNL rain-gauge network. Entirely darkened circles represent rain-gauge sites, and open circles indicate chemical sites. 
limited manpower but also because of model considerations. The predicted downwind locations of the maximum plume washout are about 33 and $50 \mathrm{~km}$, respectively, for particulates (copper, lead) and gases (sulfur, mercury). This is calculated by assuming flat terrain. However, in slightly hilly terrain such as around Plant Bowen, atmospheric diffusion may be enhanced, causing the locations of maximum ground-level concentration to be closer than expected.

The longest sampling distance from the stack in the target area (northeast sector of the 5 by 5 network) is about $25 \mathrm{~km}$. Under stable conditions, the maximum plume width at that distance is estimated to be 3.13 and $2.24 \mathrm{~km}(1.95$ and $1.4 \mathrm{miles})$, respectively, for the stahility classes $E$ and $F$ in rural areas. Both widths are less than one-half the distance between any two sites, that is, typically $6.4 \mathrm{~km}$ ( 4 miles). Because of the very narrow plume, the density of the wetfall collector network to be placed at the regular sites of the precipitation network appears too low. Thus, this density had to be increased by adding one or more collectors between the regular sites. Approximately 50 collectors will be used to ensure adequate coverage of the probable target areas. Half the collectors will be installed at the 5 by 5 network nodes; the other half will be installed between the regular sites. The number of additional collectors to be placed between sltes will depend on slte accessibility.

Installation of wetfall collectors in close proximity to the power plant calls for special attention. Unless the deposition nf heavy metalo can be proven important close to the source, it is recommended that no collectors be placed within a radius of $1.6 \mathrm{~km}$ ( $1 \mathrm{mile}$ ) from the plant. Thus, the complication arising from sources other than the smokestack plume, such as the natural-draft cooling tower plumes snt the coal pile dustfall near the stacks, will be avoided.

\subsection{Data, Acquisition, Analysis, and Discuseion}

To gain field experience and acquire data for analysis of spatial variability in wet deposition, three field collections were attempted without success: the first on January 10 through 12, 1979, the second on 
January 26 and 27, 1979, and the third on March 29 through Apr11 1, 1979. During all trips, weather prediction was followed closely by frequent contact with the National Weather Service Forecast Offices at the Atlanta airport; Dobbins Air Force Base, Birmingham, Alabama; and Knoxville, Tennessee. The contacting frequency depended on the distance between the storm system and the network and increased from daily to every $4 \mathrm{hr}$ and then to hourly.

The first trip was decided after two of the three forecasters (Knoxville, Tennessee, was not consulted) predicted the same onset of the rainfall event and amount of rain. However, the storm system arrived in northwest Georgia earlier than forecast; thus, attention was shifted to the next storm that was forecast to move in. After a long period anticipating the second storm, the experiment was called off prior to collector installation. After the event, most gauges showed a recorded amount of rain less than $6.35 \mathrm{~mm}(1 / 4 \mathrm{in}$ ) $)$ for that period.

For the second trip, because all forecasters agreed on the time of onset and the rainfall amount, the collectors were installed at preassigned sites $\sim \mathrm{hr}$ before the expected onset, according to plan. This was accomplished during the evening of January 26, 1979, (from 9:30 to 11:00 PM). Rain started at approximately 11:00 PM, but, unfortunately, the total amount was very small (trace). Another storm occurred around 12:00 noon the next day, but, by that time, the collectors had been exposed to an extended period of dry deposition.

The third trlp was undertaken during the end of March after two of three forecasters agreed on the storm onset time and precipitation amount. However, the low system was stalled over Oklahoma because of a strong persistant Bermuda high system off the Atlantic coast. After a three-day walting period, the decision was made to deploy the collectors at preassigned sites prior to an expected storm forecast for 11:00 PM on March 31, 1979. The collector deploywent was accomplished by four fieldmen during the same evening (from 6:30 to 10:00 PM). Unfortunately, the forecasted storm arrived 1-1/2 days later than expected. The storm intercepted the southwest corner of the network at 2:00 PM on April 2 and ended at 6:00 AM the next day, yiclding more than $127 \mathrm{~mm}$ ( $5 \mathrm{ln}$.) of rain. 
Although the samplers were overflooded and contaminated by two days of dryfal1, they were retrieved for bulk studies. Dryfall was expected to be at a minimum over the weekend. The retrieval was done by two staff members over a 5-hr period, $4 \mathrm{hr}$ after the event terminated (from 10:00 AM to 2:30 PM on April 3, 1979). Samples were refrigerated to reduce any chemical or biological activity and were analyzed the next day for $\mathrm{pH}$ and conductivity at room temperature.

Results are presented in Figs. 13, 14, and 15 for precipitation amount, $\mathrm{pH}$, and conductivity, respectively. Isohyets are shown in Fig. 13. The amount of rainfall for the convective storm ranges from 78.7 to

ORNL-DWG 79-5458 ETD

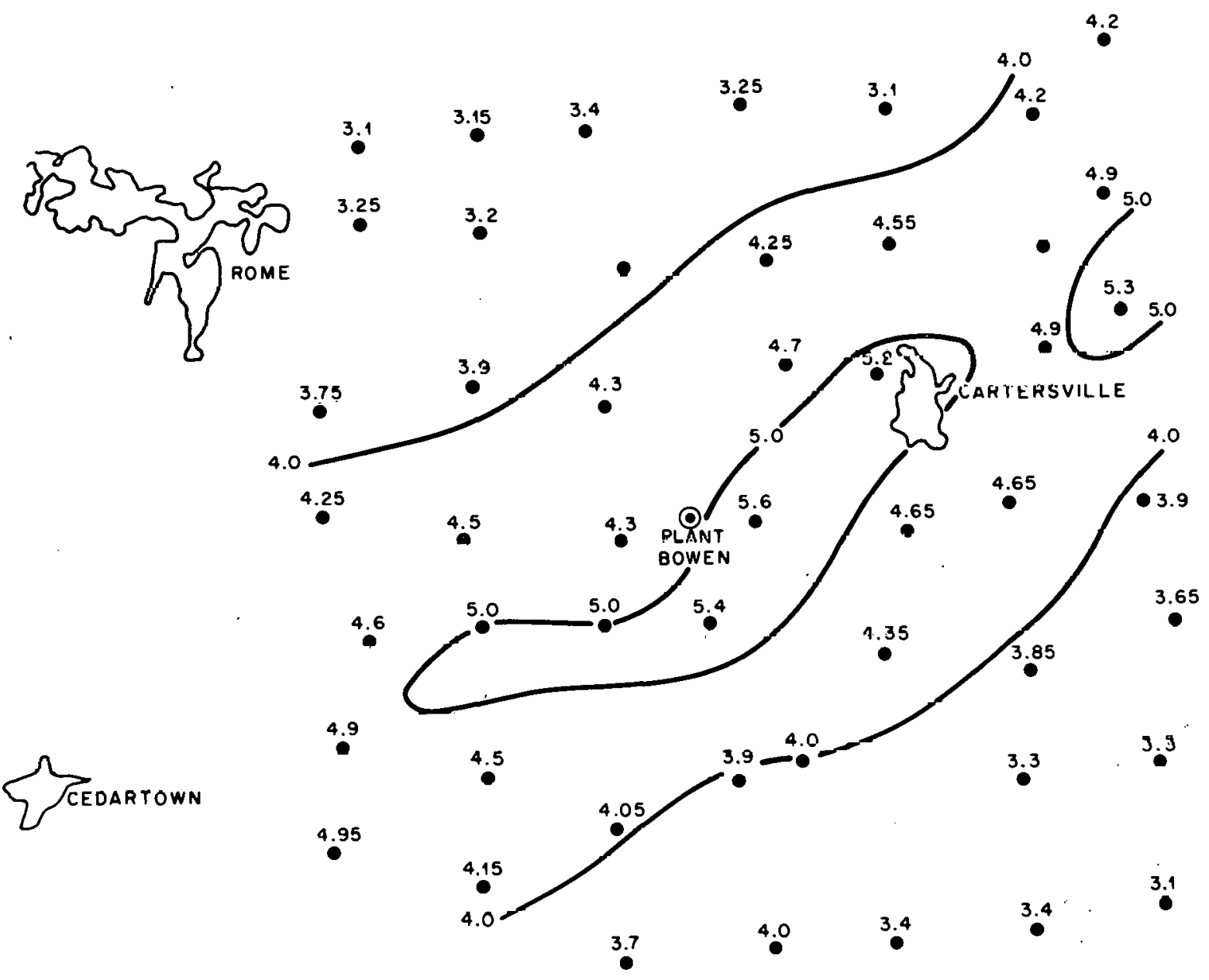

Fig. 13. Isohyet depicting the storm that passed over the METERORNL wetfall chemistry network on April 2, 1979 (started at 2:00 PM, April 2; ended 6:00 AM, April 3). 
ORNL-DWG 79-5457 ETD

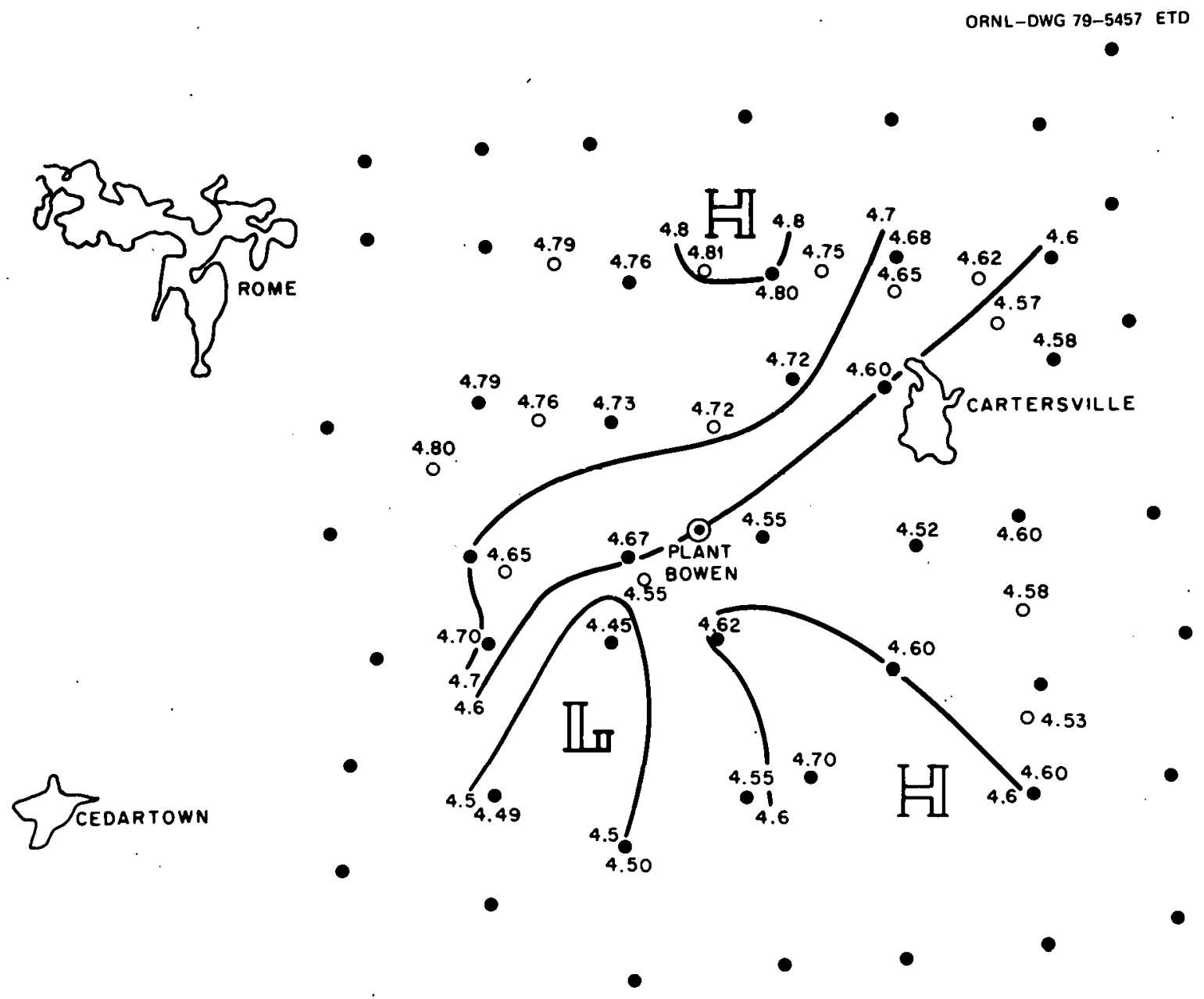

F1g. 14. Contour of equal $\mathrm{pH}$ in the METER-ORNL wetfall chemistry network for the storm of April 2, 1979.

$142.2 \mathrm{~mm}$ ( 3.1 to $5.6 \mathrm{in.})$, with a uniform band of intense rain oriented in the southwest-northeast direction decaying almost symmetrically from the band to left and right flanks. Contours of equal $\mathrm{pH}$ are shown in Fig. 14. Data with obvious conlamination (c.g., bird drnps, etc.) were disregarded. The pattern is surprisingly smooth. The range of $\mathrm{pH}$ is between 4.48 and 4.81 , with a mean, standard deviation, and coefficient of variation of $4.63,0.1$, and $2 \%$, respectively. The low and high values were found to be in the southwest and north sectors, with a difference in $\left[\mathrm{H}^{+}\right]$hy a factor of 2. Low values colncide with the target area as determined by a NNE surface wind measured at a windset $0.8 \mathrm{~km}(1 / 2 \mathrm{mile})$ 


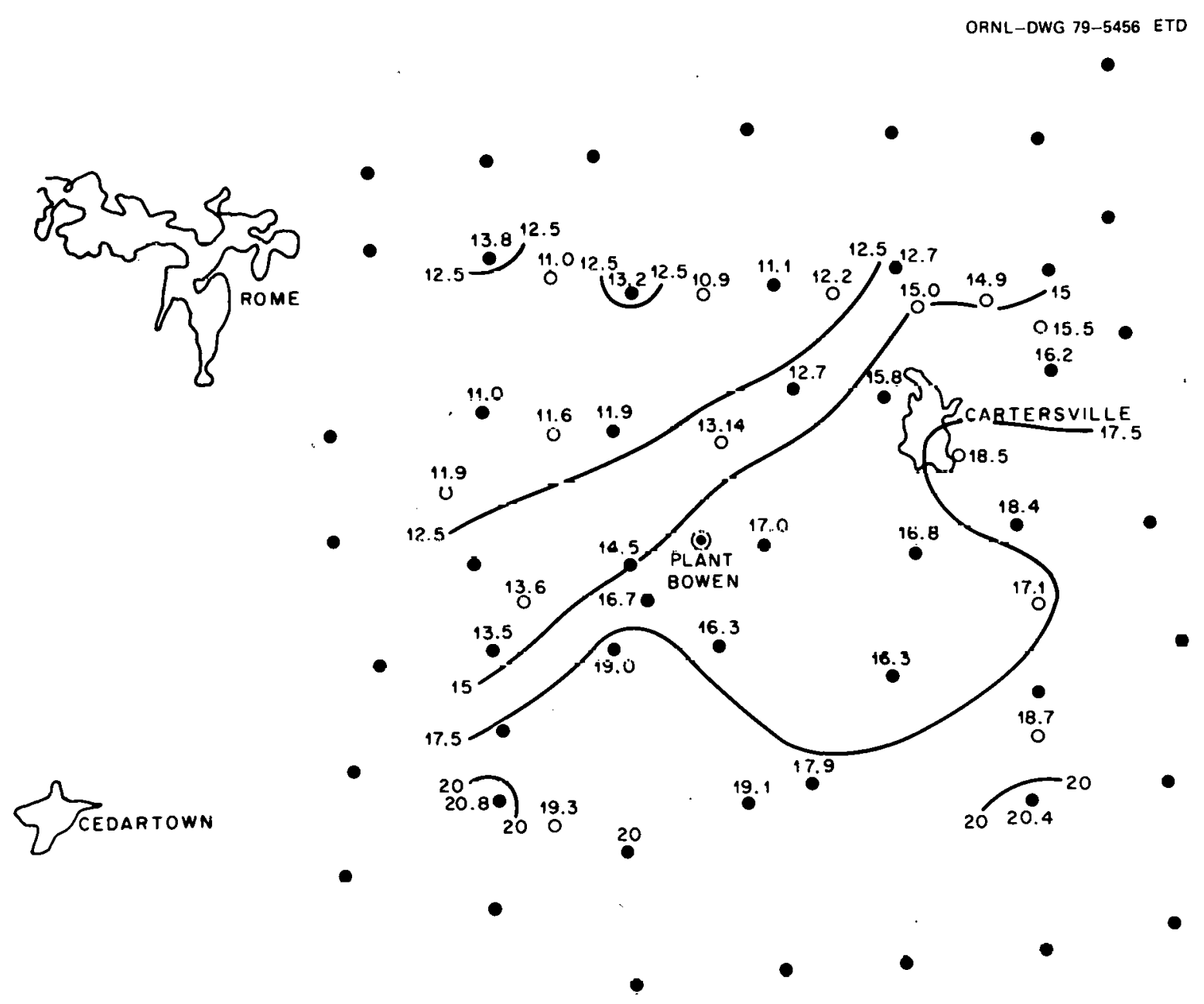
1979.

Fig. 15. Contour of equal conductivity for the storm of April 2,

north of the plant. Finally, the contours of conductivity are plotted in Fig. 15. The pattern for conductivity, as with $\mathrm{pH}$, was smooth, and the range of conductivily wao between 10.90 and $20.80 \mu$ mhos $\mathrm{cm}^{-1}$, with a mean, standard deviation, and coefficient of variation of $15.67,3.03$, and $19 \%$, respectively. The observed high conductivity and low $\mathrm{pH}$ in the WSW target area should be viewed with ekcpticism because evaluating the contribution to wetfall from dryfall components is impossible. In addition, the collectors were overfilled. 


\subsection{Data Analysis from HASL Automatic Samplers}

Two HASL automatic wetfall-only collectors were installed at strategic locations to accumulate weekly samples for exploratory studies. Be-: cause most storms in the network move from southwest to northeast, one collector was installed at the plant's meteorological station $[4.8 \mathrm{~km}$ ( 3 miles) to the northeast] and the other at the Taylorsville power substation [ $8 \mathrm{~km}(5 \mathrm{miles})$ to the southwest] to capitalize on a potential control-target situation at these locations.

The collector at the meteorological tower has been in operation since November 14, 1978, but installation at the Taylorsville site was delayed unt11 January 11, 1979, because of a power supply problem and malfunction of the rainfall sensing element. Weekly samples were analyzed routinely by the staff of Environmental Sciences Division of ORNL for $\mathrm{pH}$ and conductivity, while the concentrations of major cations and anions were analyzed by the staff of the Analytical Chemistry Division of ORNL. Rainfall amounts were measured by the recording rain gauges at nearby stations of the METER-ORNL precipitation network.

Preliminarly results of chemical analyses of samples from the automatic collectors are given in Tables 15 and 16. At the meteorological station, shown in Table 15, both $\mathrm{H}^{+}$and conductivity among the collection periods varied by a factor of about 3. The average, standard deviation, and coefficient of variation for $\mathrm{H}^{+}$are $37 \mu$ moles $11 \mathrm{ter}^{-1}$ (mean $\mathrm{pH}=4.43), 12 \times 10^{-6}$, and $32 \%$, respectively, and for the conductivity 19.64 ( $\left.\mu \mathrm{mho} \mathrm{cm}^{-1}\right), 6.51$, and $33.2 \%$, respectively. The association of the observed highest $\mathrm{pH}$ with a heavier rainfall seems to be reasonable due to the dilution of $\left[\mathrm{H}^{+}\right]$concentration caused by the large amount of rainwater collected. In addition, a weak negative correlation between $\mathrm{pH}$ and conductivity is suggested from the data, but evaluating the actual degree of correlation is impossible because of the small data base.

Analyses of samples from the Taylorsville site (Table 16) reveal much the same pattern: for $\mathrm{H}^{+}$, average $=38.1 \mu$ mole $1 \mathrm{iter}^{-1}$, standard deviation $=15.6 \times 10^{-6}$, and coefficient of variation $=41 \%$; for conductivity, average $=21.31 \mu \mathrm{mho} \mathrm{cm}^{-1}$, standard deviation $=7.24$, and coefficient of variation $=34 \%$. 
Table 15. Measured wetfall cerposition by the automatic collector installed a: the meteorclogical statior., $4.8 \mathrm{~km}$ ( $\mathrm{s}$ wlles) northeast of Plant Bowen

\begin{tabular}{|c|c|c|c|c|c|c|c|c|c|c|c|c|c|c|c|c|c|c|c|}
\hline \multirow{2}{*}{\multicolumn{2}{|c|}{ Date }} & \multirow{2}{*}{$\begin{array}{l}\text { Rainfall } \\
\text { atrount } \\
\text { (In.) }\end{array}$} & \multirow{2}{*}{$\mathrm{pH}$} & \multirow{2}{*}{$\begin{array}{l}\text { Conductfvity } \\
\left.\text { (utho } \mathrm{cm}^{-1}\right)\end{array}$} & \multicolumn{4}{|c|}{ og $l 1 t \geq x^{-1}$} & \multicolumn{6}{|c|}{$\mu \varepsilon 11 \operatorname{ter}^{-1}$} & \multicolumn{5}{|c|}{ mg liter-1 } \\
\hline & & & & & $\mathrm{Ca}^{2+}$ & $\mathrm{mg}^{2-}$ & $\mathrm{K}^{+}$ & $\mathrm{Na}^{+}$ & $\mathrm{Al}^{3+}$ & $\mathrm{Fe}^{2+}$ & $\mathrm{Ce}^{2+}$ & $\mathrm{Mn}^{2+}$ & $\mathrm{Pb}^{2+}$ & $3 n \geq+$ & $\mathrm{Cl}^{-1}$ & $\mathrm{SO}_{4}{ }^{2-}$ & $\mathrm{NO}_{3}--\mathrm{N}$ & $\mathrm{NH}_{4}{ }^{+}-\mathrm{N}$ & $\mathrm{PO}_{4}{ }^{3--} \mathrm{P}$ \\
\hline Nov. & $14-22,1978$ & 0.75 & 4.33 & 23.6 & & & & & & & & & & & & & & & \\
\hline Nov. & $22-30,1978$ & 1.00 & 4.31 & 21.1 & & & & & & & & & & & & & & & \\
\hline Yov. & 30-Dec. 7, 1978 & 2.00 & 4.60 & 11.9 & & & & & & & & & & & & & & & \\
\hline Dec. & $7-14,1978$ & 1.50 & 4.58 & 10.9 & & & & & & & & & & & & & & & \\
\hline Dec. & $14-21,1978$ & 0.75 & 4.32 & 23.0 & & & & & & & & & & & & & & & \\
\hline Jan. & $1.1-18,1979$ & 0.35 & 4.43 & 22.0 & 0.3 & 00,52 & 0.02 & 0.07 & 22 & 7.5 & 0.14 & 1.4 & 5.4 & $i \vdots$ & 0.17 & 1.53 & 0.280 & & $<0.001$ \\
\hline Jan. & $18-25, \quad 1979$ & 2.70 & 4.42 & 18.1 & 0.26 & $0 \mathrm{C2}$ & 0.01 & 0.10 & 23 & 9.6 & 0.18 & 0.86 & 7.4 & 26 & 0.22 & 1.57 & 0.235 & & $<0.001$ \\
\hline Feb. & $1-8,1979$ & 1.45 & 4.68 & 15.5 & 0.22 & $<001$ & 0.07 & 0.16 & 16 & 5.3 & 0.04 & 1.0 & 3.9 & $2 \bar{\epsilon}$ & 0.52 & 1.70 & 0.152 & 0.068 & $<0.001$ \\
\hline Feb. & $15-22,1979$ & 1.60 & 4.35 & 29.4 & & & & & & & & & & & & & & & \\
\hline Feb. & 22-Mar. 1, 1979 & 3.20 & 4.52 & 16.1 & & & & & & & & & & & & & & & \\
\hline Mar. & $1-8,1979$ & 5.20 & 4.67 & 13.2 & & & & & & & & & & & & & & & \\
\hline Mar. & $8-14,1979$ & 0.60 & 4.25 & 30.9 & & & & & & & & & & & & & & & \\
\hline
\end{tabular}

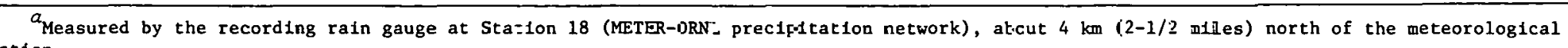
station. 
Table 16. Measured wetfall composizion by the automatic collector installed at the Taylorsville power substation, $8 \mathrm{~km}$ ( 5 m1les) southwest of Plant Bowen

\begin{tabular}{|c|c|c|c|c|c|c|c|c|c|c|c|c|c|c|c|c|c|c|}
\hline \multirow{2}{*}{ Date } & \multirow{2}{*}{$\begin{array}{l}\text { Rainfall } \\
\text { amount }{ }^{a} \\
(\text { In. })\end{array}$} & \multirow{2}{*}{$\mathrm{pH}$} & \multirow{2}{*}{$\begin{array}{l}\text { Conductivity } \\
\text { (umho } \mathrm{cm}^{-1} !\end{array}$} & \multicolumn{4}{|c|}{ mg 11 ter $^{-1}$} & \multicolumn{6}{|c|}{ HB $11 \operatorname{ter}^{-1}$} & \multicolumn{5}{|c|}{ mg liter ${ }^{-1}$} \\
\hline & & & & $\mathrm{Ca}^{2+}$ & $\mathrm{Mg}^{2+}$ & $\mathrm{K}^{+}$ & $\overline{\mathrm{Na}^{+}}$ & $\mathrm{Al}^{3+}$ & $\mathrm{Fe}^{2+}$ & $\mathrm{Cd}^{2+}$ & $\mathrm{Mn}^{2+}$ & $\mathrm{Pb}^{2+}$ & $2 n^{2+}$ & $\mathrm{Cl}^{-1}$ & $\mathrm{SO}_{4}{ }^{2-}$ & $\mathrm{NO}_{3}--\mathrm{N}$ & $\mathrm{NH}_{4}{ }^{+}-\mathrm{N}$ & $\mathrm{PO}_{4}{ }^{3-}-\mathrm{P}$ \\
\hline $\begin{array}{l}\text { Jan. } 11-18,1979 \\
\text { Jan. } 18-25,1979 \\
\text { Feb. } 1-8,1979 \\
\text { Feb. } 15-22,1979 \\
\text { Feb. } 22-\text { Mar. } 1,1979 \\
\text { Mar.. } 1-8,1979 \\
\text { Mar. } 8-14,1979\end{array}$ & $\begin{array}{l}0.45 \\
2.50 \\
1.50 \\
1.50 \\
2.00 \\
5.40 \\
0.45\end{array}$ & $\begin{array}{l}4.40 \\
4.48 \\
4.72 \\
4.2 \\
4.48 \\
4.60 \\
4.27\end{array}$ & $\begin{array}{l}22.3 \\
18.5 \\
11.1 \\
32.0 \\
19.4 \\
16.7 \\
29.2\end{array}$ & $\begin{array}{l}0.28 \\
0.24 \\
0.26\end{array}$ & $\begin{array}{l}0.026 \\
0.02 \\
<0.01\end{array}$ & $\begin{array}{l}0.04 \\
0.03 \\
0.02\end{array}$ & $\begin{array}{l}0.11 \\
0.09 \\
0.02\end{array}$ & $\begin{array}{l}25 \\
23 \\
31\end{array}$ & $\begin{array}{c}6.5 \\
12 \\
4.5\end{array}$ & $\begin{array}{l}0.53 \\
0.21 \\
0.14\end{array}$ & $\begin{array}{l}1.2 \\
1.3 \\
0.67\end{array}$ & $\begin{array}{l}8.1 \\
7.1 \\
3.8\end{array}$ & $\begin{array}{l}23 \\
25 \\
15\end{array}$ & $\begin{array}{l}0.19 \\
0.17 \\
0.19\end{array}$ & $\begin{array}{l}1.46 \\
1.51 \\
1.00\end{array}$ & $\begin{array}{l}0.366 \\
0.178 \\
0.149\end{array}$ & 0.053 & $\begin{array}{l}<0.001 \\
<0.001 \\
<0.001\end{array}$ \\
\hline
\end{tabular}

Measured by the recording raln gauge at Station 31 (METER-ORNL prec1p1tation network), about 2.4 kon (1-1/2 a1les) southwest of the Taylorsville sutstation. 
Intersite comparison of the analytical results revealed significantly higher concentrations of $\mathrm{K}^{+}, \mathrm{Na}^{+}, \mathrm{Cd}^{2+}, \mathrm{Cl}^{-}$, and $\mathrm{SO}_{4}{ }^{2-}$ at the meteorological station than at the Taylorsville station for the first week in February. Although this finding at first suggested the possibility of a plume effect at the meteorological station, subsequent analysis of wind data for the same period eliminated any such possibility. Only one storm passed over the network during the week of February 1. This storm started at 12 noon on February 6 and ended at 4 AM the next day. During the storm, the surface and upper-air winds were easterly and souther1y, respectively. With these winds, the target area would be $10-$ cated in the northwest quadrant rather than in the northeast. The apparent abnormality at the meteorological station thus could probably be attributed to local industrial emissions at Cartersville, Georgia, under the persistent easterly surfare wind. These results clearly indicate some of the complexities associated with wetfall chemistry studies in areas with multiple local sources. 


\section{SUMMARY AND RECOMMENDATIONS}

From the review of sulfur washout models, three basic models are identified, depending on the assumptions involved: chemical, physical, and combined chemical and physical. The majority of models apply a Gaussian model for plume dispersion, consider a single species in raindrops, and assume an uncatalyzed liquid-phase oxidation of $\mathrm{SO}_{2}$.

The main finding from this review is that the discrepancy in predicted sulfate production rate differs by about four orders of magnitude (from $10^{-14}$ to $10^{-10}$ moles 1 iter ${ }^{-1} \mathrm{sec}^{-1}$ for a solution with a $\mathrm{pH}$ of 3 ). Some of these discrepancies can be attributed to different assumptions about the variation of sulfate production rate with $\mathrm{pH}$. The sulfate production rate is found to be inversely proportional to the hydrogen concentration raised to the powers of $1,1-1 / 2$, and 2 for the Hill and Adamowicz, Fuller and Crist, and Scott and Hobbs models, respectively. Thus, the assumptions on sulfate production rate (either being proportional to sulfite or bisulfite concentration) are crucial in determining sulfur washout.

At the present time, given the state of the art, no model can claim superfority over any other model without data verification. The Dana et al. model, tested against Centralia data, is an exception. Predicted values for $\mathrm{SO}_{4}{ }^{2-}$ are in the same order of those observed, but the predicted $\mathrm{SO}_{2}$ (dissolved and dissociated) exceeds that observed by more than one order of magnitude. The discrepancy was attributed to the inadequacy of the adopted Scott and Hobbs ammonia model for $\mathrm{SO}_{2}$ oxidation. This should be resolved by further improvement, both in model development and field data measurements.

Highlights of the preliminary measurements and predictions associated with studies of METER-ORNL wetfall chemistry network at Plant Bowen include the following.

1. With a light shower rainfall type $\left(5 \mathrm{~mm} \mathrm{hr}^{-1}\right)$, the predicted maximum wet deposition rate is about 60 and $0.01 \mu$ moles $\mathrm{m}^{-2} \mathrm{hr}^{-1}$. for gaseous sulfur and mercury. at a downwind distance of $50 \mathrm{~km}$ from the stack and 3.67 and $0.96 \mu$ moles $\mathrm{m}^{-2} \mathrm{hr}^{-1}$ for particulate matter of copper and lead at $33 \mathrm{~km}$ from the same source. 
2. There are presently no data on sulfur and trace metals deposition to verify the predicted maximum wet deposition rate; however, the predicted sulfur wet deposition (about $2.24 \mathrm{~g} \mathrm{~m}^{-2}$ year $^{-1}$ ) is comparable to the maximum representative annual average wet deposition in heavily industrialized areas in North America ( $3 \mathrm{~g} \mathrm{~m}^{-2}$ year $\left.^{-1}\right)$.

A continuous monitoring of ralnfall rate, $\mathrm{pH}$, conductivity, and other key constituents using HASL automatic samplers at Plant Bowen's meteorological station over a period of 12 weeks and at Taylorsville power substation over 7 weeks showed variable results with no consistent pattern. One abnormality in concentration of $\mathrm{K}^{+}, \mathrm{Na}^{+}, \mathrm{Cd}^{2+}, \mathrm{Cl}^{-1}$, and $\mathrm{SO}_{4}{ }^{2-}$ during the week of February 1 through 8, 1979, at the meteorological station is attributed primarily to the local emissions from industries located at Cartersville, Georgia, rather than to emission from Plant Bowen. This suggeste the need fur event sampling to minimize variable rain volume and multiple-source effects often associated with weekly samples.

Based on considerations of theoretical estimates and on constraints of the existing rain-gauge network, manpower, and site accessihility, the METER-ORNL wetfall chemistry network was designed for pilot studies to optimize network density and siting. The resulting network is composed of the 5 by 5 inner subset $[27$ by $27 \mathrm{~km}$ ( 17 by $17 \mathrm{miles})]$ of the 7 hy 7 raingauge network, with 18 temporary sites located at preassigned control and target areas.

Guided by the present study and those rernmmentations of the workshop on dry and wet deposition, ${ }^{37}$ research is needed in the following areas for a better understanding of precipitation scavenging at Plant Bowen so that the process may be more realistically included and parameterized in models:

1. adequate emissions inventory for $\mathrm{SO}_{\mathrm{x}}, \mathrm{NO}_{\mathrm{x}}$, and trace metals data (source characteristics);

2. quantitative understanding of $\mathrm{SO}_{4}{ }^{2-}$ incorporation into precipitation, including aircraft measurements of vertical profiles, correlation of precipitation sulfate with atmospheric $\mathrm{SO}_{2}$ and $\mathrm{SO}_{4}{ }^{2-}$ concentrations, and measurements of dissolved $\mathrm{SO}_{2}$ in precipitation at various heights; 
3. measurements of all possible precipitation constituents that affect sulfur and trace metals chemistry and acidity.

Finally, some guidelines for precipitation-scavenging experiments at Plant Bowen are given in the following discussion.

With respect to data acquisition, one of the most important elements is the need for a unfform and persistent precipitation. Without that, severe random dilution or enrichment of the "underplume" samples is inevitable. The success of data acquisition further depends on the accurate weather predictions. To avoid depending entirely on the weather forecasts and, at the same time, to avold lnvesting in an expensive, totally automatic network, three alternate plans are suggested.

1. The first alternate plan calls for an increase in the confidence level of the forecasts above which a field trip for sample collection would be initiated. Although this increase of confidence level [e.g., from a $60 \%$ chance of rain to a $90 \%$ chance with the amount of predicted rainfall exceeding at least $19 \mathrm{~mm}(3 / 4 \mathrm{in.})]$ may cause a high probability of missing several acceptable storms, the chance for a successful operation once initiated is relatively enhanced.

2. The second alternate plan calls for a reduction in manpower. If a compromise in sample standards and the number of sites can be reached, the reduction in manpower is considerable. This can be achieved by ignoring temporary sites and allowing the proposed tolerance in duration of dryfall contamination to be extended from 3 to $12 \mathrm{hr}$. Under these conditions, it is theoretically possible for one fieldman to prepare the regular 5 by 5 network for collection in one day.

3. The last alternate plan calls for the installation of up to 12 automatic collectors at strategic locations. Based on information of surface and upper-air winds, some strateglc sites in the control and target areas could be identified. Continuous monitoring of wetfall chemistry over a period of one or more years and trajectory analysis would possibly provide the necessary statistical significance of any potential wet deposition effect from the smokestack plumes. 


\section{REFERENCES}

1. Sweden's Case Study, "Alr Pollution Across National Boundaries: The Impact on the Environment of Sulfur in Air and Precipitation," Stockholm: Royal Ministry for Foreign Affairs and Royal Ministry of Agriculture" (1971).

2. L. Granat, "Sulfate in Precipitation as Observed by the European Atmospheric Chemistry Network," Atmos. Environ. 12, 413-24 (1978).

3. G. E. Likens et al., "Productivity of Forest Ecosystems," in Proceedings of the Brussels Symposium, P. Duvigneaud, ed., Unesco Publicatiuns, Paris, 1969.

4. M. C. McCracken, "MAP3S; An Investigation of Atmosplielle, EnergyRelated Pollutants in the Northeastern United States," Atmos. Environ. 12, 649-59 (1978).

5. J. N. Ga1loway and E. B. Cowling, "The Effects of Precipitation on Aquatic and Terrestrial Ecosystems: A Prnnosed Precipitation Cliemlsery Network," J. Air Pollut. Control Assoc. 28(3), 229-35 (1978)

6. J. M. Hales, J. M. Thorp, and M. A. Wolf, Field Investigation of Sulfur Dioxide Washout from the Plume of a Large Coal-Fired Power Plant by Natural Precipitation, NTIS Report PB-203-129, Battelle Pacific Northwest Laboratories, Richland, Washington (1971).

7. M. T. Jána, D. R. Drewes, D. W. Glover, and J. M. Hales, "Precipitation Scavenging of Fossil-Fuel Effluents," Report EPA-600/4-76-031, Battelle Pacific. Northwest Laboratories, Richland, Washington (1971).

8. T. Y. Lt and H. E. Iandsberg, "Rainwater pH Close to a Major Power P1ant," Atmos. Environment, 9, 81-88 (1975).

9. H. A. Wiebe and D. M. Whelpdale, "Precipitation Scavenging from a Tal1-Stack Plume," p. 118 in Precipitation Scavenging, Report CoNF741003 (1977).

10. R. Varney, and B. M. McCormac, "Atmospheric Pollutants," in Atmospheric Polzution, B. M. McCormac, ed., D. Reidel Publishing Company, Dordrecht, Holland, 1971.

11. K. H. Rasmussen, R. L. Kabel, and M. Taheri, "Sources and Natural Remova1 Processes for Some Atmospheric Pollutants," Report EPA-650/ 4-74-032 (1974).

12. J. J. Jansen, "A Study of Acid Prectpitation in the New York Metropolitan Area," Master's Thesis, Polytechnic Institute of New York (1975). 
13. G. E. Likens, "Acid Precipitation," Chem. Eng. News 22, 29-44 (1976).

14. G. E. Likens and F. H. Bormann, "Acld Rain: A Serious Regional Environmental Problem," Science 184, 1176-79 (1974).

15. R. M. Perhac, "Sulfate Regional Experiment in Northeastern United States: The 'SURE' Program," Atmos. Environ. 12, 641-47 (1978).

16. W. E. Wilson, "Sulfates in the Atmosphere: A Progress Report on Project MISTT," Atmo6. Environ. 12, 537-47 (1978).

17. R. L. Miller, R. E. Saylor, and A. A. N: Patrinos, The METER-ORNL Precipitation Network: . From Design to Data Analysis, Report ORNL/ TM-6523 (1978).

18. S. E. Lindberg et al., "Walker Branch Watershed Element Cycling Studies: Collection and Analysis of Wetfall for Trace Elements and Sulfate," pp. 125-150 in Watershed Research in Eastern North America, D. Correll, ed., Smithsonian Institution Press, Edgewater, Maryland, 1977.

19. F. B. Hill and R. F. Adamowicz, "A Model for Rain Composition and the Washout of Sulfur Dioxide," Atmos. Environ. 11, 917-27 (1977).

20. W. D. Scott, and P. V. Hobbs, "The Formation of Sulfate in Water Droplets," J. Atmos. Sciences 24, 54-57 (1967).

21. C. Junge and T. G. Ryan, "Study of the $\mathrm{SO}_{2}$ Oxidation in Solution and its Role in Atmospheric Chemistry," $Q$. J.R. Meteorol. Soc. 84 , 46-55 (1958).

22. A. P. Van den Heuval and B. J. Mason, "The Formation of Ammonium Sulfate in Water Droplets Exposed to Gaseous Sulfur Dioxide and Ammonia," Q. J. R. Meteorol. Soc. 89, 271-75 (1963).

23. J. M. Hales, M. A. Wolf, and M: T. Dana, "A Linear Model for Predicting the Washout of Pollutant Gases from Industrial Plumes," AIChE $J$. 19, 292-97 (1973).

24. J. M. Hales, J. M. Thorp, and M. A. Wolf, "Washout of $\mathrm{SO}_{2}$ from the Plume of a Coal-Fired Power Plant," p. 293 in Precipitation Scavenging, Report CONF-700601 (1971).

25. J. M. Hales, "Fundamentals of the Theory of Gas Scavenging by Rain," Atmos. Environ. 6, 635-59 (1972).

26. M. T. Dana, J. M. Hales, and M. W. Wolf, "Rain Scavenging of $\mathrm{SO}_{2}$ and Sulfate from Power Plant Plumes," $J$. Geophys. Res. 80, 4119-29 (1975). 
27. M. E. Smith and I. A. Signer, "An Improved Method of Estimating Concentrations and Related Phenomena from a Point Source Emission," $J$. Appl. Meteorol. 5, 63-639 (1966).

28. S. Beilke, D. Lamb, and J. Muller, "Heterogeneous Oxidation of $\mathrm{SO}_{2}$ in Relation to Atmospheric Scavenging," p. 137 in Precipitation Scavenging, Report CONF-741003 (1977).

29. R. Gunn and G. D. Kinzer, "The Terminal Velocity of Fall for Water Droplets in Air," J. Met. $\underline{6}, 243-48$ (1949).

30. A. C. Best, "The Size Distribution of Raindrops." Q. J. R. Meteorol. Soc. $76,16-36$ (1950):

31. J. A. Garland, "Dry and Wet Removal of Sulfur from the Atmosphere," Atmos. Environ. 12, 349-62 (1978).

32. D. A. Hegg and P. V. Hobbs, "Oxidation of Sulfur Dioxide in Aqueous Systems with Particular Reference to the Atmosphere," Atmos. Environ. 12. 241-53 (1978).

33. S. Beilke and G. Gravenhorst, "Heteorogeneous $\mathrm{SO}_{2}$ - Oxidation in the Droplet Phase," Atmos. Environ. 12, 231-39 (1978).

34. E. C. Fuller and R. H. Crist, "The Rate of Oxidation of Sulfite Ions by Oxygen," J. Am. Chem. Soc. 63, 1644-50 (1978).

35. H. A. C. McKay, "The Atmospheric Oxidation of Sulfur Dioxide in Water Droplets in the Presence of Ammonia," Atmos. Environ. 5, 7-14 (1971).

36. L. A. Barrie and H. W. Georgii, "An Experimental Investigation of the: Absorption of Sulfur Dioxide by Water Drops Containing Heavy Metal Ions," Atmos. Environ. 10, 743-46 (1976).

37. R. B. Husar, J. P. Lodge, Jr., and D. J. Moore, eds., "Sulfur in the Atmosphere," Atmos. Environ. 12, 1-796 (1978).

38. A. A. N. Patrinos, N. C. J. Chen, and R. L. Miller, Spatial Correlations of Precipitation in Northwest Georgia, Report ORNL/TM-6524 (1978).

39. R. Young, private communication (1978).

40. C. E. Billings et al., "Mercury Balance on a Large Pulverized CoalFired Furnace," J. Air Pollut. Control Assoc. 23, 773-77 (1973).

41. S. S. Ray and F. G. Parker, Characterization of Ash from Coal-Fired Power Plants, Report EPA-600/7-77-010 (1977)

42. I. Sanemasa, "The Solubility of Elemental Mercury Vapor in Water," Bull. Chem. Soc. Jpn 48, 1795-98 (1975). 
43. J. H. McCarty, Jr., et al., "Mercury in the Atmosphere," pp. 3739 in Mercury in the Environments, U.S. Geological Survey Professional Paper No. 713 (1970).

44. R. H. Perry and C. H. Chilton, Chemical Engineer's Handbook, 5th ed., McGraw-H111 Company, New York, 1973.

45. R. A. Wallace et al., Mercury in the Environment, Report ORNL/NSP/ EP-1 (1971).

46. J. D. Hem, "Chemical Behavior of Mercury in Aqueous Media," pp. 19-24 in Mercury in the Environment, U.S. Geological Survey Professional Paper No. 713 (1970).

47. D. H. Peirson et al., "Trace Elements in the Atmospheric Environment," Nature 241, 252-56 (1973).

48. A. W. Andren and S. E. Lindberg, "Atmospheric Input and Origin of Selected Elements in Walker Branch Watershed, Oak Ridge, Tennessee," Water, Air, Soil Pollut. 8, 199-215 (1977).

49. R. H. Ross, "Environmental Interactions," in Environmental, Health, and Control Aspects of Coal Conversion: An Information Overview, Report ORNL/EIS-95 (1977).

50. I. Van der Hoven, "Deposition of Particles and Gases," pp. 202-208 In Meteorology and Atomic Energy - 1968, D. H. Slade, ed., Report TID-24190 (1968).

51. G. E. Stout and F. A. Huff, "Rainout Characteristics for Hydrological Studies," pp. 61-72 in Isotopes in Hydrology, International Atomic Energy Agency, Vienna, Austria (1967).

52. D. F. Gatz, "Spatial Variability of Aerosol Deposition in Rain Near St. Louio," paper presented for the American Chemical Society, Honolulu, Hawaii (1979).

53. R. Semonin and H. Volchek, "Site Selection and Certification," Site Committee on National Atmospheric. Deposition Program, NC-141 (1978). 


\section{THIS PAGE}

\section{WAS INTENTIONALLY}

LEFT BLANK 
ORNL/TM-6930

\section{Internal Distribution}

1. S. I. Auerbach
2. C. F. Baes
3. S. Baron
4. H. F. Bauman
5-29. N. C. J. Chen
30. R. G. Chenoweth, Jr.
31. W. E. Cooper
32. W. B. Cottrell
33. C. C. Coutant
34. D. M. E1ssenberg
35. H. L. Falkenberry
36. C. Feldman
37. M. H. Fontana
38. W. Fulkerson
39. M. J. Goglia
40. E. C. H1se
41. H. W. Hoffman
42. L. Jung
43. R. J. KedI
44. E. C. Kovnegar
45. D. Lee .
46. M. Levenson
47. S. E. Lindberg
48. R. E. MasPhersnn.

49. H. A. McLain

50. R. L. Miller

51. R: D. Murphy

52-61. A. A. N. Patrinos

62. J. L. Rich

63. M. W. Rosenthal

64. T. H. Row

65. R. E. Saylor

66. I. Spiewak

67. H. E. Trammel

68. D. B. Trauger

69. R. R. Turner

70. G. D. Whitman

71. W. J. Wilcox

72. A. J. Witten

73. ORNL Patent Office

74-75. Central Research Office

76. Document Reference Section

77-79. Laboratory Records Department

80. Laboratory Records (RC)

81. Nuclear Safety Information Center

82. EISO Library

\section{External Distribution}

83. R. F. Adamowicz, Department of Applied Science, Brookhaven National Laboratory, Upton, NY 11973

84. D. S. Ballentine, Division of Biomedical and Environmental. Research, U.S. Department of Energy, Washington, D.C. 20545

85. G. A. Briggs, Atmospheric Turbulence Diffusion Laboratory, NOAA; Oak Ridge, TN 37830

86. T. Brna, Environmental Protection Agency, Research Triangle Park, NC 27711

87: J. H. Coleman, Air Quality Branch, Tennessee Valley Authority, River Oaks Building, Muscle Shoals, AL 35660

88. M. T. Dana, Atmospheric Sciences Department, Battelle Pacific Northwest Laboratorles, Battelle Boulevard, Richland, WA 99352

89. R. A. Dirks, National Science Foundation, $1800 \mathrm{G}$ Street, Northwest, Washington, DC 20550

90. R. L. Drake, Battelle Pacific Northwest Laboratories, Battelle Boulevard, Richland, WA 99352 
91. J. E. Fairobent, Office of Nuclear Reactor Regulation, U.S. Nuclear Regulatory Commission, Washington, DC 20555

92. P. Frenzen, Argonne National Laboratory, 9700 South Cass Avenue, Argonne, IL 60439

93. J. N. Galloway, Department of Environmental Sciences, University of Virginia, Charlottesville, VA 22903

94. J. A. Garland, AERE, Harwel1, Didcot, Oxon, England

95. D. Gatz, Illinois State Water Survey, Box 232, Urbana, IL 61801

96. C. H. Goodman, Southern Company Services, Inc., P.0. Box 2625, Birmingham, AL 35202

97. C. Hakkarinen, Electric Power Research Institute, P.0. Box 10412, Palo Alto, CA 94303

98. S. R. Hanna, Atmospheric Turbulence Diffusion Laboratory, NOAA, Oak Ridge, TN 37830

99. B. B. Hicks, Argonne National Laboratory, 9700 South Cass Avenue, Argonne, IL 60439

100. F. B. Hill, Department of Applied Science, Brookhaven National Laboratory, Upton, NY 11973

101. P. Hobbs, Department of Atmosperic Sciences, University of Washington, Seattle, WA 98192

102. R. P. Hosker, Atmospheric Turbulence Diffusion Laboratory, NOAA, Oak Ridge, TN 37830

103. J. Jansen, Southern Company Services, Inc., P.0. Box 2625, Birmingham, AL 35202

104. L. R. Koenig, Rand Corporation, 1700 Main Street, Santa Monica, CA 90406

105. K. Kornastewicz, Office of Standards Development, U.S. Nuclear Regulatory Commission, Washington, DC 20555

106. G. Likens, Department of Ecology and Systematics, Curnell University, Ithaca, NY 14853

107. J. Mauthetsch, Eleotric Power Research Institure, P.U. Box 10412, Palo Alto, CA 94303

108. H. Moses, Division of Biomedical and Environmental Research, Department of Energy, Washington, DC 20545

109. J. Motz, Georgia Power Company, P.0. Box 4545, Atlanta, GA 30302

110. F. W. Murray, Rand Corporation, 1700 Main Street, Santa Monica, CA 90406

111. C. J. Nappo, Atmospheric Turbulence Diffusion Laboratory, NOAA, Oak Ridge, TN 37830

112. H. D. Orville, Institute of Atmospheric Scicnces, South Dakula School of Mines and Technology, Rapid C1ty, SD 57701

113. R. Pena, Department of Meteorology, The Pennsylvania State University, University Park, PA 16802

114. R. Perhac, Electric Power Research Insititute, P.0. Box. 10412, Palo Alto, CA 94303

115. S. Rau, Atmospheric Turbulence Diffusion Laboratory, NOAA, Oak Ridge, TN 37830

116-125. A. Rubin, Advanced Systems and Materials Production Division, Department of Energy, Washington, DC 20545 
126. W. F. Savage, Division of Nuclear Research and Applications, Department of Energy, Washington, DC 20545

127. G. L. Sherwood, Division of Nuclear Research and Applications, Department of Energy, Washington, DC 20545

128. D. H. Slade, Division of Blomedical and Environmental Research, Department of Energy, Washington, DC 20545

129. W. G. N. Slinn, Atmospheric Sclences Department, Oregon State University, Corvallis, OR 97331

130. S. Strauch, Division of Nuclear Research and Applications, Department of Energy, Washington, DC 20545

131. D. W. Thomson, Department of Meteorology, The Pennsylvania State University, University Park, PA 16802

132. L. Winiarski, Environmental Protection Agency, 200 South 35th Street, Corvallis, OR 97330

133. R. Young, Georgia Power Company, P.0. Box 4545, Atlanta, GA 30302

134. Office of Assistant Manager, Energy Research and Development, DOE, ORO

135. Director, Reactor Division, DOE, ORO

136-162. Technical Information Center, DOE 